\title{
INTERAÇÃO GENÓTIPOS X AMBIENTES E IMPLICAÇÕES PARA O MELHORAMENTO DA SOJA
}

\author{
JORGE OMAR GIECO
}

Engenheiro Agrônomo

Orientador: Prof. Dr. ISAIAS OLÍVIO GERALDI

\begin{abstract}
Dissertação apresentada à Escola Superior de Agricultura "Luiz de Queiroz", Universidade de São Paulo, para obtenção do título de Mestre em Agronomia, Área de Concentração: Genética e Melhoramento de Plantas.
\end{abstract}

\section{PIRACICABA}

Estado de São Paulo- Brasil

Novembro - 1997. 
Dados Internacionais de Catalogação na Publicação (CIP) DIVISÃo DE BIBLIOTECA E DOCUMENTAÇĀO - Campus "Luiz de Queiroz"/USP

Gieco, Jorge Omar

Interaçao genótipos $x$ ambientes e implicaçōes para o melhoramento da soja / Jorge Omar Gieco. - - Piracicaba, 1997

$98 \mathrm{p}$.

Dissertação (mestrado) - - Escola Superior de Agricultura Luiz de Queiroz, 1997.

Bibliografia.

1. Interação genótipo-ambiente 2. Melhoramento genético vegetal 3. Progênie vegetal 4. Soja

CDD 633.34 


\title{
INTERAÇÃO GENÓTIPOS X AMBIENTES E IMPLICAÇÕES PARA O MELHORAMENTO DA SOJA
}

\author{
JORGE OMAR GIECO
}

Aprovada em: 13.01.1997

Comissão julgadora:

Prof. Dr. ISAIAS OLÍVIO GERALDI (Orientador) ESALQ/USP

Prof. Dr. LUIS EDUARDO ARANHA CAMARGO ESALQ/USP

Dr. LUCIANO LOURENÇO NASS CENARGEN/EMBRAPA

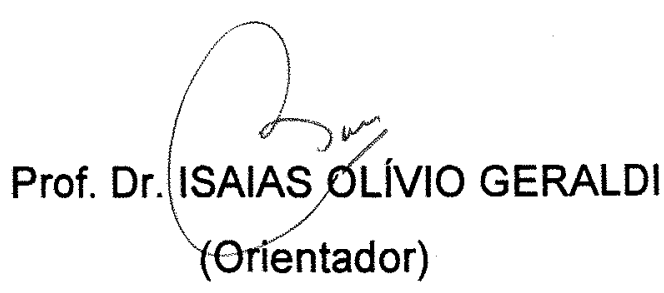


A minha esposa,

María del Valle Basanta

\section{OFEREÇO}

aos meus pais,

Osvaldo Juan Gieco

Etelvina Margarita D. Boretto

\section{DEDICO}




\section{AGRADECIMENTOS}

- A Deus pela sua permanente presença, especialmente nos momentos difíceis.

- À minha esposa María del Valle Basanta pela sua permanente companhia, amor, estímulo e colaboração.

- Ao Prof. Dr. Isaias Olívio Geraldi pela orientação, amizade, e pela permanente colaboração e apoio na realização deste trabalho.

- A Fundação Coordenação de Aperfeiçoamento de Pessoal de Nível Superior (CAPES), pela bolsa de estudos fornecida no periodo de abril de 1996 a dezembro de 1997.

- Ao amigo Cristian Andrés Carranza pela incalculável ajuda na realização das análises estatísticas.

- Ao colega Paulo A. V. Barroso pela oportuna ajuda nas correções de português.

- Aos funcionários do grupo Soja, Fernandes de Araújo e Gustavo Perina, e aos demais funcionários do campo, pelo apoio permanente na realização dos trabalhos de campo.

- Às funcionárias da Biblioteca do Departamento de Genética da ESALQ-USP, Silvana Marchizelli Gregório e Aparecida Elizabeth Santos da Silva pela sua permanente vontade de colaboração. 
- Às autoridades do Instituto Nacional de Tecnología Agropecuaria (INTA) Manfredi, Córdoba-Argentina, especialmente ao no seu momento Diretor Eng. Agr. Arístides Mosciaro, por haver-me possibilitado o início na investigação, particularmente na área de melhoramento vegetal.

- Ao Eng. Agr. (PhD) Daniel Horacio Basigalup pela sua orientação no meu primeiro trabalho de pesquisa, pela sua amizade, e por sua incondicional disponibilidade para colaborar no momento requerido.

- A todos os companheiros dos grupos alfafa e sorgo da EEA-MANFREDI, pela sua amizade, colaboração e pelos gratos momentos compartilhados durante minha permanência nesse lugar.

- A meus pais, Etelvina e Osvaldo pelo seu permanente apoio e compreensão. 


\section{SUMÁRIO}



SUMMARY ...............................................................................

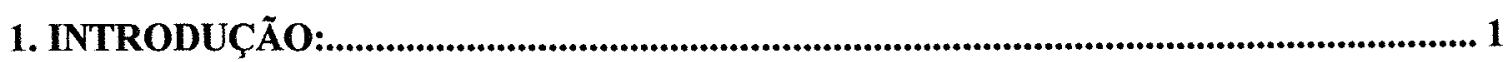

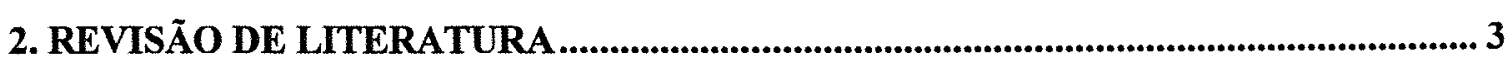

2.1 INTERAÇÃO GENÓTIPO X AMBIENTE: ............................................................... 3

2.2 METODOLOGIAS DISPONÍVEIS PARA AVALIAR A INTERAÇÃO GENÓTIPO X

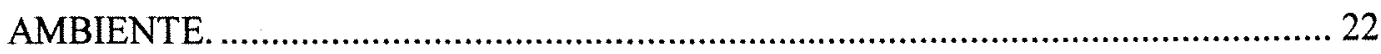

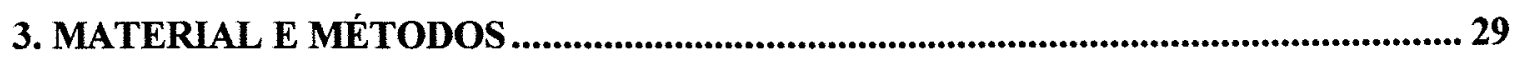

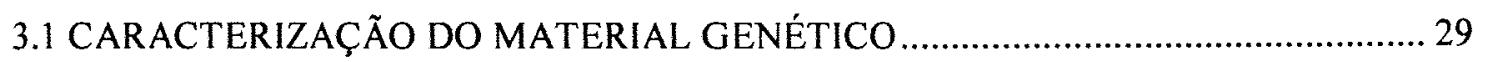

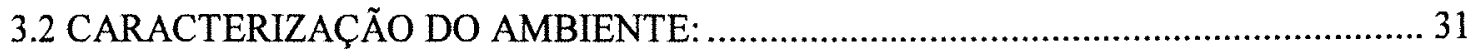

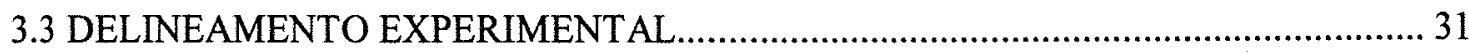

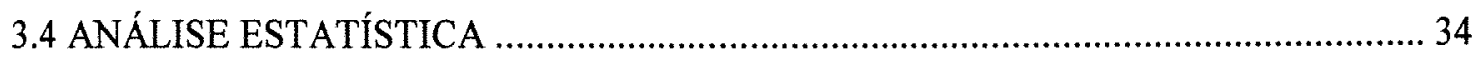

3.4.1 ANÁLISE DE VARIÂNCIA INDIVIDUAL PARA CADA ANO DE AVALIAÇÃO E PARA CADA CONJUNTO DE PROGÊNIES ............................................................34

3.4.2 ANÁLISE DE VARIÂNCIA INDIVIDUAL PARA CADA ANO DE AVALIAÇÃO

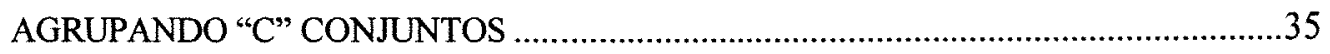

3.4.3 ANÁLISE DE VARIÂNCIA CONJUNTA PARA OS TRÊS ANOS DE AVALIAÇÃO E

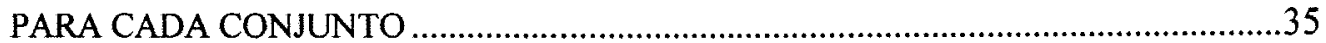

3.4.4 ANÁLISE DA VARIÂNCIA CONJUNTA E AGRUPADA PARA “C” CONJUNTOS ..........36

3.4.5 ANÁLISE DOS COMPONENTES GENÉTICOS E FENOTÍPICOS DA INTERAÇÃO

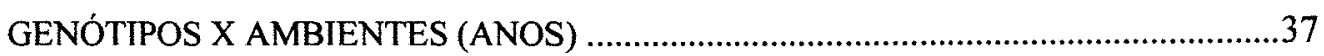

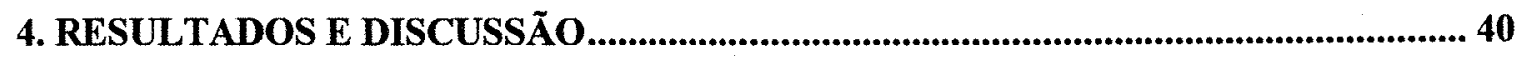

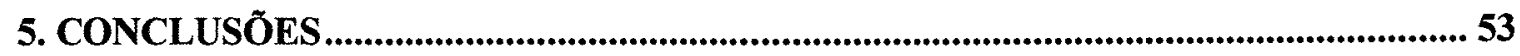

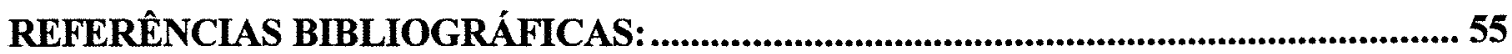

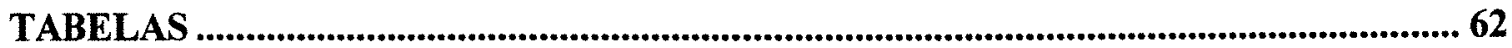

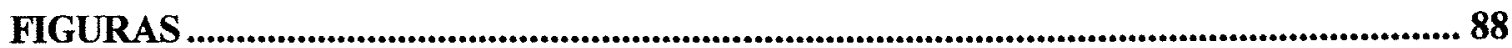




\title{
INTERAÇÃO GENÓTIPOS X AMBIENTES E IMPLICAÇÕES PARA O MELHORAMENTO DA SOJA
}

\author{
Autor: JORGE OMAR GIECO \\ Orientador: Prof. Dr. ISAIAS OLIVIO GERALDI
}

\section{RESUMO}

O objetivo do presente trabalho foi a quantificação dos componentes da interação genótipo $x$ ambiente, mais precisamente genótipo $x$ ano, em progênies provenientes de cruzamentos biparentais de soja [Glycine max (L.) Merrill.] e suas implicações no melhoramento. Três populações denominadas 1,2 , e 3 ; oriundas dos cruzamentos BR 80-14853 x PI-165896, PI-123439 x PI-239235 e GAÚCHA x OC 79230 respectivamente; compostas de 60 linhagens homozigóticas aleatórias obtidas pelo metodo SSD (Single seed descent), foram avaliadas em relação ao caráter produtividade de grãos, em uma localidade (Piracicaba, S.P.-BRASIL) durante três anos agrícolas: 1993/94, 1994/95 e 1995/96. Empregou-se um delineamento em blocos ao acaso modificado com três repetições e parcelas lineares de um metro de comprimento por 0,50 metro de largura, contendo 17 plantas após o desbaste. A população 3 foi em média superior quanto à produção de grãos, seguida pelas populações 1 e 2 , respectivamente. Detectou-se variabilidade genética altamente significativa para as três populações, indicando a possibilidade de seleção de linhagens superiores. Detectou-se também uma interação genótipos $x$ ambientes (progênies $x$ anos) altamente significativa para todas as populações avaliadas. $A$ análise dos componentes da interação fenotípicos e genéticos demonstrou que o componente complexo da mesma foi predominante em alto grau (média 
das três populações: $90,91 \%$ e $96,03 \%$, para os componentes genéticos e fenotípicos, respectivamente). As implicações da predominância do componente complexo da interação nos programas de melhoramento foram estudadas e discutidas em detalhe no presente trabalho. 


\title{
GENOTYPE X ENVIRONMENT INTERACTIONS AND ITS IMPLICATIONS IN SOYBEAN BREEDING
}

\author{
Author: JORGE OMAR GIECO \\ Adviser: Prof. Dr. ISAIAS OLIVIO GERALDI
}

\section{SUMMARY}

The objective of this work was the quantification of the interaction genotype $x$ environment components, more precisely genotype $x$ year interaction, in progenies derived from single crosses in soybeans [Glycine max (L.) Merrill.] and its implications in soybean breeding. Three populations named 1, 2 and 3 derived from the crosses BR 80-14853 $\times$ PI-165896, PI-123439 $\times \mathrm{PI}-239235$ and GAÚCHA x OC 79230 respectively; composed of 60 random inbred lines derived by single seed descent method, were evaluated for seed yield at one location (Piracicaba, S.P.-BRASIL), during three growing seasons (1993/94, 1994/95 and 1995/96). A modified randomized complete block design with three replications was employed and plots consisted of single 1 meter long row spaced 0.50 meter apart, with 17 plants after thinning. Population 3 was on the average superior for grain yield, followed by populations 1 and 2 respectively. Highly significant genetic variability was detected for the three populations, showing the possibility of selecting superior lines. Highly significant genotype $x$ environment interactions (progenies $x$ years) were also detected for all the populations evaluated. The phenotypic and genetic components of interaction analysis indicated that complex component was highly predominant (mean of three populations equal to $90.91 \%$ and $96.03 \%$ for genetic and phenotypic components respectively). The implications of complex component of interaction were discussed in details in this work. 


\section{INTRODUÇÃO:}

De modo geral os materiais genéticos tais como cultivares, progênies e demais recursos genéticos em processo de melhoramento são cultivados em uma ampla gama de condições ambientais; compreendendo diferentes tipos de solo, niveis de fertilidade, conteúdo hídrico, temperatura e práticas culturais. Esta somatória de variáveis que afetam direta e indiretamente a produtividade da cultura são denominadas de ambiente. Quando os materiais são comparados em diferentes ambientes, seu desempenho relativo pode não manifestar consistência. Um cultivar pode ser altamente produtivo em alguns ambientes, enquanto que outro cultivar pode ser altamente produtivo em outros ambientes. Esta mudança no desempenho relativo dos genótipos em diferentes ambientes é denominada de modo geral como interação genótipo $x$ ambiente. É fundamental ter conhecimento deste tipo de interação para praticar esquemas seletivos que compreendam vários anos de avaliação, com o propósito de se realizar uma seleção consciente e correta. A falta de registro deste tipo de interação pode nos levar a situações errôneas como a seleção de um material supostamente superior, com base na avaliação em poucos ambientes, mas cujo desempenho não se repete em outros ambientes.

Por outro lado, este tipo de interação pode ser aproveitado favoravelmente quando se pretende desenvolver materiais para ambientes específicos como, por exemplo, ambientes de alta fertilidade, umidade e emprego de insumos. Os genótipos que apresentam uma interação favorável com esses ambientes poderão ser selecionados. A mesma situação pode ocorrer para o caso particular de materiais adaptados a ambientes pobres ou estressantes. Finalmente pode ser necessário liberar materiais de grande 
amplitude de adaptação, e neste caso, a interação com os ambientes deve ser a menor possível.

O objetivo do presente trabalho compreendeu a quantificação dos componentes da interação genótipo $x$ ambiente, mais precisamente genótipo $x$ ano, em progênies provenientes de cruzamentos biparentais de soja, e suas implicações com o melhoramento. 


\section{REVISÃO DE LITERATURA}

\subsection{INTERAÇÃO GENÓTIPO X AMBIENTE:}

Allard (1971), definiu a expressão fenotípica de um determinado caráter, como por exemplo a produtividade (representada por F), como a somatória de uma série de fatores, ou seja: $F=\mu+G+E+(G E)$. Nesta expressão, o valor numérico do fenótipo $(F)$ é considerado como sendo a soma da média geral da população $(\mu)$, do efeito genotípico $(G)$, do efeito ambiental $(E)$ e do efeito da interação genótipo $x$ ambiente (GE). Um dado genótipo ou ambiente pode ter um efeito positivo ou negativo em relação à média, conforme sua ação seja de aumentar ou diminuir a produtividade em torno da média geral da população. $O$ termo (GE), referente à interação, será nulo somente se todos os genótipos tiverem um comportamento consistente em todos os ambientes, isto é, se não houver interações genótipo por ambiente. Qualquer definição prática dos termos $\mu, G, E$, e GE deve ser dada em termos fenotípicos pois as próprias mensurações são necessariamente de natureza fenotípica. Neste sistema, portanto, o efeito de um genótipo é definido somente em relação a outros genótipos. Para esta relação ter alguma utilidade geral, deve ser considerado um certo número de ambientes para que possa-se obter o seu valor médio. Se este efeito relativo não for constante, de ambiente para ambiente, haverá uma variabilidade que será refletida pelo termo de interação. Do ponto de vista do melhorista de plantas, os valores genotípicos devem ser medidos em relação a um grupo particular de ambientes. Estes ambientes são, em geral, os que ocorrem num período de anos, num certo número de locais e dentro de uma área geográfica relativamente homogênea. Se a análise for conduzida 
abrangendo diferentes locais e épocas, o fenótipo $(F)$ pode ser representado como: $F=\mu+G+R+L+A+(G L)+(G A)+(L A)+(G L A)+E$. Nesta expressão, $\mu$ e $G$ representam a média geral e o efeito genotípico; $R, L$, e $A$ são os efeitos diretos de repetições, locais e anos, respectivamente e $E$ constitui um erro composto que engloba os efeitos restantes (efeito da parcela, erro devido à amostragem e erros de mensuração). As combinações de símbolos indicam interaçōes entre os efeitos principais, representando (GL), (GA), (LA) e (GLA) as interações genótipo $x$ local, genótipo $x$ ano, local $x$ ano e genótipo $x$ local $x$ ano, respectivamente.

Romagosa \& Fox (1994), definiram a interação genótipo $x$ ambiente como a expressão genotípica diferencial através de diferentes ambientes. Esta expressão diferencial reduziria a associação entre os valores fenotípicos e genotípicos, e pode determinar que materiais selecionados como adequados para um ambiente podem não ser adequados em outros, forçando os melhoristas de plantas a examinar a adaptação genotípica dos materiais.

A medição da interação genótipo $x$ ambiente é também importante para determinar uma estratégia ótima de melhoramento, com a finalidade de desenvolver genótipos específicos para determinados ambientes em particular. De forma geral, o termo genótipo $x$ ambiente inclui tanto a variação espacial como a temporal, ou seja, pode compreender diferentes locais e diferentes periodos de tempo, tais como meses e anos.

O ambiente é um termo geral que inclui uma série de condições sob as quais as plantas crescem, e pode envolver sítios ou locais, anos, práticas culturais ou de manejo, ou a combinação de todos esses fatores. Comumente cada local e ano é considerado um ambiente diferente. De modo geral denomina-se de "experimento" um grupo de genótipos sistematizados, crescendo em um ou mais ambientes. Cada fator que forma parte do ambiente 
da planta possui o potencial de provocar uma performance diferencial da mesma, estando estreitamente associada à interação genótipo $x$ ambiente.

Allard \& Bradshaw (1964) classificaram as variáveis ambientais em dois grupos: previsiveis e imprevisiveis. As variáveis previsiveis são aquelas que ocorrem de forma sistemática ou estão sob controle humano, tais como o tipo de solo, data de semeadura, espaçamento entre fileiras, densidade de semeadura, e níveis de fertilidade. Por outro lado, as variáveis imprevisíveis caracterizam-se por flutuar inconsistentemente e incluem precipitações, temperatura, umidade relativa e eventos climáticos tais como geadas, granizo, etc.

As variáveis previsiveis podem ser avaliadas individualmente ou de forma conjunta em relação a sua interação com os genótipos. Assim, podem ser praticados estudos individualizados de interação, tais como genótipo $x$ tipo de solo, genótipo $x$ data de semeadura e genótipo $x$ espaçamento de semeadura; ou considerar todos esses fatores de forma conjunta resultando em uma interação generalizada do tipo genótipo $x$ ambiente.

Os fatores imprevisiveis determinam as interações de genótipos $x$ localidades e genótipo $x$ anos, como também interações mais complexas tais como genótipos $x$ locais $x$ anos.

A performance relativa dos genótipos através dos diferentes ambientes determina a importância de uma interação. Não existe interação genótipo $x$ ambiente quando a performance relativa dos genótipos permanece constante nos diferentes ambientes onde os mesmos foram avaliados.

As interações genótipo $x$ ambiente podem manifestar-se de duas formas alternativas: a)- A diferença entre genótipos pode variar, mas sem alteração no seu posicionamento relativo, ou classificação b)- $O$ posicionamento relativo dos cultivares pode mudar nos diferentes ambientes onde os mesmos são avaliados. 
Fehr (1987), definiu uma série de prioridades referentes à interação genótipo $x$ ambiente que deveriam ser consideradas pelos melhoristas: a)- $A$ necessidade de se desenvolver cultivares para fins especificos estaria determinada por um adequado entendimento da interação dos genótipos com os fatores ambientais previsiveis. b)- A necessidade potencial de gerar um único cultivar adaptado às diferentes áreas geográficas requer um conhecimento exaustivo das interações genótipo $x$ localidade. A importância desta interação pode determinar a necessidade de se subdividir uma ampla área geográfica em subáreas, com a finalidade de se testar novos genótipos e obter dados da performance dos mesmos que possam ser empregados pelos produtores. c)- $\mathrm{A}$ efetiva disponibilidade de recursos para se testar ou avaliar genótipos através de diferentes localidades e anos deverá basear-se na importância relativa das interações genótipo $x$ local, genótipo $x$ ano e genótipo $x$ local $x$ ano. d)- As respostas dos genótipos em relação à variável nivel de produtividade entre ambientes possibilitará um entendimento de sua estabilidade. Isto permitirá determinar quais genótipos se comportaram de forma mais adequada nos ambientes que apresentaram flutuações nas condições de crescimento da cultura.

Uma serie de trabalhos foram desenvolvidos em soja com a finalidade de avaliar as interações genótipos $x$ ambientes e suas implicações nos esquemas seletivos. Entre eles destancan-se os realizados por Erickson et al. (1982), os quais avaliaram 115 familias $F_{3}$ provenientes do cruzamento de Glycine max (L.) Merrill. x Glycine soja Sieb \& Zucc., com a finalidade de registrar os efeitos das interações genótipo $\mathrm{x}$ ambiente sobre o conteúdo de proteína das sementes. Em um primeiro estudo avaliaram 15 famílias $F_{3}$ em dois locais e dois anos. 0 componente de variância estimado para familias foi altamente significativo $(p<0,01)$. As estimativas dos componentes de variância para as interações família $x$ ano e família $\times$ local foram não significativas, enquanto que 0 
componente família $x$ localidade $x$ ano foi significativo. Em um segundo estudo, os autores avaliaram 100 famílias $F_{3}$ em dois locais. Eles detectaram diferenças altamente significativas entre famílias para o caráter estudado. Além disso, também encontraram uma correlação altamente significativa entre conteúdo de proteina $e$ as diferentes localidades. Por outro lado, as familias que apresentavam alto conteúdo de proteína em alguns locais, não repetiam esta performance em outros locais, demonstrando uma elevada interação do caráter com o ambiente. Um trabalho similar foi conduzido por Xiangxun et al. (1992), os autores analisaram a variação do conteúdo de proteína e óleo ao longo das localidades e anos em quatro cultivares de soja, em três anos de avaliação. Os efeitos avaliados foram: cultivar, ano, localidade e a interação ano $x$ localidade. Com relação aos caracteres conteúdo de proteína e óleo, os resultados da análise da variância demonstraram que os efeitos de cultivar, ano, localidade e a interação ano $x$ localidade foram altamente significativos. Os autores também detectaram que o fator localidade teve um efeito maior que o fator ano sobre 0 conteúdo de proteína, óleo e proteína + óleo.

Alguns autores avaliaram os efeitos das variáveis previsíveis (data de semeadura, espaçamento entre fileiras, densidade de semeadura, condicões de cultura, etc.) sobre a produtividade da cultura de soja. Entre estes trabalhos destacam-se os conduzidos por Herbert \& Litchfield (1982), estes autores estudaram os efeitos da densidade de semeadura e espaçamento entre fileiras sobre os componentes da produtividade (peso de 1000 grãos, número de vagens/ planta, número de sementes/ vagem e tamanho de sementes), durante dois anos agrícolas em soja. A produtividade de grãos aumentou em $31 \%$ quando a distância entre fileiras diminuiu de $75 \mathrm{~cm}$ para $25 \mathrm{~cm}$, enquanto que quando a distância entre fileiras reduziu de $50 \mathrm{~cm}$ para $25 \mathrm{~cm}$ o incremento de produtividade foi de $14 \%$. No referente a densidade de semeadura, a produtividade sofreu um incremento de 13 a $27 \%$ quando a densidade de 
semeadura oscilou de baixa ( 25 sementes $/ \mathrm{m}^{2}$ ) a intermediária ( 80 sementes/ $\mathrm{m}^{2}$ ). A densidade de semeadura alta (135 sementes $/ \mathrm{m}^{2}$ ) não mostrou diferenças significativas em relação à produtividade quando foi comparada com a densidade intermediária. O número de vagens por planta e por nó foram os componentes da produtividade mais afetados pelo incremento da distância entre fileiras e a densidade de semeadura. No referente ao número de sementes por vagem e ao tamanho de sementes, não se observou uma resposta significativa à modificação da densidade de semeadura e à distancia entre fileiras. Os autores não encontraram diferenças significativas entre os dois anos de avaliação para os componentes da produtividade. Neste mesmo contexto Panter \& Allen (1989), desenvolveram uma pesquisa com a finalidade de determinar quais dos cultivares de soja, selecionados para serem cultivados em condições de cultura única, adaptaram-se favoravelmente as condições de cultura dupla (double-cropping). Os autores avaliaram a produtividade de grãos de 25 linhagens $F_{4}$ de crescimento determinado e 25 linhagens $F_{4}$ de crescimento indeterminado sob condições de cultura única e de dupla cultura. Os testes foram realizados em 16 locais e durante cinco anos. As linhagens foram separadas em dois grupos com base na sua produtividade, contendo o primeiro deles as 17 linhagens mais produtivas em ambos regimes de cultura, e o segundo as demais linhagens consideradas inferiores. Foram detectadas interações significativas linhagens $x$ ambientes para ambos grupos, no entanto a magnitude desta interação foi duas vezes superior no grupo de linhagens consideradas inferiores. Finalmente Konieczny et al. (1992) estudaram a interação de 25 genótipos de soja, com os fatores ambientais fotoperíodo, temperatura e abastecimento hídrico, durante três anos, com a finalidade de selecionar genótipos adequados a ambientes específicos. Os autores encontraram diferenças significativas entre anos para as variáveis avaliadas. No primeiro e segundo ano de avaliação, o período emergência-floração representou $32 \%$ do ciclo total, enquanto que no terceiro ano de avaliação este 
período só representou $24,7 \%$ do ciclo total. A duração do período de floração foi consideravelmente mais longo durante o terceiro ano devido à presença de baixas temperaturas. Os autores encontraram uma forte interação genótipo $x$ ano para o caráter duração do período de floração. Uma situação semelhante foi constatada para o caráter período de enchimento de grãos. Nos dois primeiros anos de avaliação este periodo foi relativamente curto, já no terceiro, o período de enchimento de grãos foi consideravelmente mais longo.

A incidência dos fatores previsiveis sobre a produtividade de grãos também foi avaliada em numerosas culturas por varios autores.

Bationo et al. (1990), analisaram os efeitos da densidade de semeadura e da fertilização nitrogenada no milheto pérola [Pennisetum glaucum (L.) R. Br.] sobre os componentes da produtividade em uma única localidade e no decorrer de três anos. Os autores detectaram diferenças altamente significativas entre os diferentes anos de avaliação no referente aos componentes da produtividade. Tais diferenças foram motivadas por um comportamento diferencial das precipitações, o qual determinou um maior aproveitamento do fertilizante nos anos com maiores precipitações, afetando de forma positiva a produtividade e seus componentes.

Singh et al. (1989), desenvolveram uma pesquisa em feijão (Phaseolus vulgaris L.), com a finalidade de estudar os efeitos dos niveis de insumos sobre a eficiência da seleção para produtividade de grãos, comparar os ganhos genéticos relativos para produtividade em cruzamentos envolvendo indivíduos pertencentes a pools genéticos diferentes, e analisar a estabilidade genotípica das linhas selecionadas. Os autores empregaram progênies derivadas de seis cruzamentos entre indivíduos pertencentes a diferentes pools gênicos, praticando uma seleção massal para produtividade de grãos em plantas individuais nas gerações $F_{2} \in F_{3}$, coletando plantas individuais na geração $F_{4}$. Desde a geração $F_{5}$ até a geração $F_{8}$ a seleção baseou-se em ensaios de produtividade. As seis linhas de maior produtividade de cada 
cruzamento e em cada ambiente foram comparadas com cinco parentais de alta produtividade e quatro testemunhas, sob condições de alto e reduzido emprego de insumos, durante um periodo de três anos. Os autores observaram diferenças significativas entre anos, cruzamentos, e linhagens dentro de cruzamentos para todos os caracteres avaliados. Sob condições de reduzido emprego de insumos manifestou-se uma diminuicão da produtividade da ordem de $31 \%$, e uma diminuição do peso das sementes de $7 \%$, enquanto a maturação foi acelerada.

Singh \& Gutiérrez (1990), empregaram o método do pedigree com seleção precoce para produtividade de grãos praticada desde $F_{2}$ até $F_{7}$ em duas populações de feijão (Phaseolus vulgaris L.), e empregando três densidades de semeadura (66, 133 e 266 mil plantas por hectare). As sete linhas de alta produtividade selecionadas provenientes de cada densidade de semeadura foram posteriormente avaliadas em um delineamento látice $7 \times 7$ com três repetições e com três densidades de semeadura, no transcorrer de dois anos. A seleção das linhas por produtividade baseou-se em sua performance média e na média dos parentais. A mesma mostrou-se efetiva para todas as densidades de semeadura e nos dois anos. Os autores não encontraram diferenças significativas entre a produtividade média das linhas selecionadas em densidades de semeadura intermediárias e altas. Os efeitos de densidade de semeadura, ano e suas interações sobre a produtividade foram significativos.

Brown et al. (1990), avaliaram o efeito de três épocas de corte (1: cortes praticados ao $10 \%$ florescimento; 2 : cortes ao $10 \%$ florescimento + um corte ao ano posposto até $50 \%$ de florescimento e 3 : cortes ao $50 \%$ de florescimento) em dois cultivares de alfafa (Medicago sativa L.) com a finalidade de registrar o efeito das mesmas na produtividade e no conteúdo de carboidratos nas raízes, empregando três ambientes e durante o transcurso de dois anos. Os dois cultivares manifestaram uma produtividade satisfatória nas três localidades quando foram submetidos ao primeiro tratamento (corte ao $10 \%$ 
de florescimento). A colheita ao $50 \%$ de florescimento não representou vantagem nenhuma com relação à modalidade anterior. Os autores não detectaram efeitos significativos de cultivar e época de corte no conteúdo de carboidratos nas raízes nas três localidades. No referente à produtividade (kg. de matéria seca/hectare) foi detectado um efeito significativo de anos, épocas de corte e interação anos $x$ épocas de corte nas três localidades.

Caravetta et al. (1990), estudaram os efeitos da distância entre fileiras sobre a morfologia de quatro genótipos de sorgo [Sorghum bicolor (L.) Moench.], em duas localidades e no transcurso de dois anos agricolas. As distâncias entre fileiras empregadas foram $5,10,15,30$ e $60 \mathrm{~cm}$. Diferenças significativas foram detectadas para a maioria dos caracteres morfológicos entre genótipos e dentro de espaçamentos entre fileiras. De modo geral, o número de caules por planta aumentou a medida que o espaçamento entre fileiras foi crescendo. O mesmo comportamento manifestaram o diâmetro do caule principal e dos perfilhos assim como o quociente folha/caule. A interação genótipo $x$ distância entre fileiras foi significativa em ambas localidades e anos de avaliação.

Outros autores manifestaram sua preferencia pelos métodos da análise de estabilidade clássicos. Neste sentido Mebrahtu \& Elmi (1997), utilizaram a técnica da análise de estabilidade genotípica por meio da regressão, proposta por Eberhart \& Russell (1966), com a finalidade de obter uma ferramenta auxiliar no esquema de seleção de parentais para hibridação em um programa de soja para consumo humano. Os autores utilizaram dez genótipos, os quais foram cultivados durante três anos agricolas (1993, 1994 e 1995) em uma única localidade e empregando três datas de semeadura $(30 / 4,15 / 5$ e $30 / 5)$. Os genótipos foram avaliados no estado de vagem verde (entre $R_{6}$ e $R_{7}$ ). Utilizando uma análise da variância conjunta para os três anos detectaram variações significativas entre anos para os caracteres número de vagens verdes e peso de 
100 vagens. Também detectaram uma interação significativa genótipo $x$ ano para ambos caracteres avaliados, indicando que os genótipos não manifestaram estabilidade de um ano para outro. Finalmente, os autores concluiram que seriam necessários vários anos de avaliação para poder determinar com precisão o potencial genético dos genótipos analisados.

Por outra parte uma serie de pesquisas foram conduzidas em diversas culturas com a finalidade de desenvolver materiais que possuam uma maior "homeostase ambiental". Com base nesta proposta Jensen (1952), sugeriu que as variedades multilinhas de aveia (Avena sativa L.) apresentavam uma vantagem relativa, quando comparadas com as obtidas a partir de uma linha pura. Isto seria devido a uma maior estabilidade produtiva, uma ampla adaptação ambiental e uma maior proteção contra as doenças. No mesmo sentido Allard \& Bradshaw (1964), sugeriram que as populações heterozigotas e heterogêneas oferecem uma melhor oportunidade para produzir variedades que exibam uma reduzida interação genótipo $x$ ambiente. Visando um objetivo similar Sprague \& Federer (1951), analisando dados de produtividade de milho (Zea mays L.) em vários ambientes, obtiveram evidência de que os híbridos duplos interagiam menos com os ambientes, em comparação com os hibridos simples. Em outras palavras, os hibridos duplos manifestaram-se superiores aos híbridos simples em relação à estabilidade de performance. Resultados similares foram registrados por Eberhart et al.(1964), os autores verificaram que quando dois tipos de híbridos de milho eram comparados num mesmo experimento, as interações híbrido $\mathrm{x}$ ano foram significativamente maiores para os hibridos simples do que para os hibridos triplos.

Com base na revisão da literatura foi possível definir dois enfoques diferentes a respeito do problema derivado da interação genótipos $\mathrm{x}$ ambientes. No inicio, os pesquisadores centraram sua atenção em desemvolver medidas de 
estabilidade complexas, visando obter materiais com uma adaptacão ampla. Com o decorrer do tempo verificou-se que tais medidas nem sempre refletían a estabilidade real de um determinado genótipo. Devido a isto, varios autores começaram a enfocar o problema desde outro ángulo. Foi assim que em lugar de tentar desenvolver genótipos estáveis com adaptação ampla, os pesquisadores centraram sua atenção na escolha de ambientes espeçíficos para o desenvolvimento e à avaliação de cultivares. Esta metodologia tem como objetivo maximizar a produtividade dos materiais em determinados ambientes, praticando tudo o processo seletivo destinado ao desenvolvimento de novos materiais em ambientes selecionados previamente através de uma avaliação de sua capacidade preditiva (previsão do desempenho dos futuros cultivares). Em outras palavras, este enfoque dá prioridade ao desenvolvimento de materiais com adaptação específica.

No primeiro enfoque enquadram-se os trabalhos de Virk et al. (1984), estes autores efetuaram uma análise de regressão empregando diversos índices ambientais, em 20 híbridos e 13 compostos de milheto pérola [Pennisetum typhoides (L.) R. Br.], em 19 locais, com a finalidade de avaliar sua estabilidade relativa e comparar os resultados obtidos, resultantes da aplicação dos diversos índices. Os autores detectaram uma interação genótipos $x$ ambientes altamente significativa, atribuindo a mesma ao componente não linear, consideraram ademais que o quadrado médio dos desvios $\left(S_{\text {di }}^{2}\right)$ seria um parâmetro importante para selecionar cultivares estáveis. Eles também encontraram que a produtividade média de grãos esteve associada positivamente com os coeficientes de regressão e o quadrado médio dos desvios. Todos os hibridos e compostos manifestaram uma adaptabilidade geral. A aplicação de diversos índices ambientais teve pouca importância na interpretação do resultado da análise de regressão. Com objetivos semelhantes Altman et al. (1989), determinaram as variâncias genéticas e ambientais, suas interações, a herdabilidade, e a estabilidade genotípica dos pigmentos foliares 
(terpenóides) de algodão (Gossypium hirsutum L.). Os autores montaram um experimento para avaliar a interação genótipo $x$ ambiente, incluindo 14 genótipos os quais possuiam um conteúdo de terpenóides variando desde normal até muito elevado, em cinco locais e durante dois anos. As magnitudes dos componentes de variância para a interação genótipo $x$ ambiente foram muito pequenas, e menores que o resto dos componentes da variância genética. $O$ análise da estabilidade determinou coeficientes de regressão variando de 0,06 a 2,11 . Os autores concluíram que os melhoristas podem selecionar com eficiência para alto conteúdo de terpenóides, sendo esta uma característica altamente desejável pois determina a resistência a pragas. Continuando dentro da mesma linha de pesquisa Campbell \& Kern (1982), registraram dados de produtividade e qualidade em beterraba açucareira (Beta vulgaris L.), durante quatro anos e em cinco localidades, com a finalidade de determinar a presença e a magnitude das interações genótipo $x$ ambiente. $A$ regressão das produtividades médias dos cultivares com a média da produtividade dos cultivares em todos os ambientes, e a contribuição dos cultivares individuais ao componente de variância cultivar $\mathrm{x}$ ambiente indicaram que os cultivares diferiam em relação a sua potencialidade de responder favoravelmente aos diferentes ambientes.

Aguiar et al. (1989), avaliaram 400 progênies de meios-irmãos de milho (Zea mays L.) provenientes da população CMS-39, em três localidades durante um ano agricola, com a finalidade de verificar o potencial desta população para - melhoramento e para detectar a existência da interação progênies $x$ ambientes. Os autores utilizaram um delineamento látice $20 \times 20$ com duas repetições, e cada parcela foi constituída por uma linha de cinco metros. As estimativas dos parâmetros fenotípicos e genéticos obtidas para peso das espigas mostraram que a população apresentava uma elevada variabilidade genética. Constataram também que a estimativa da variância da interação progênies $x$ ambientes foi relativamente alta, indicando a necessidade de que 
as progênies sejam avaliadas em mais de um ambiente. A estimativa do ganho genético esperado com seleção entre as famílias foi de $10,28 \%$. Finalmente o desdobramento da interação progênies $x$ locais mostrou que ela é devida, em grande parte, à falta de correlação entre o desempenho das progênies nos vários locais.

Finalmente Branch et al. (1991), propuseram o emprego da seleção seqüencial com a finalidade de minimizar os efeitos da interação genótipo $x$ ambiente. O método envolve seleções precoces cíclicas em diferentes ambientes, de modo oposto aos esquemas que praticam seleção em uma mesma localidade cada ano.

No segundo enfoque da problemática podem ser citadas as pesquisas conduzidas pelos seguintes autores: Misevic \& Dumanovic (1989), desenvolveram um estudo com a finalidade de selecionar localidades de avaliação individuais, assim como grupos de localidades a serem utilizadas como sítios para testar a produtividade de hibridos de milho (Zea mays L.). Eles avaliaram a produtividade dos híbridos em 12 localidades e no decorrer de dez anos. O potencial preditivo de cada local foi determinado com base nas correlações entre as médias das localidades e a média geral ( $r>0.95)$, a regressão linear das médias das localidades em relação a média geral $(b>1)$, $e$ os $10 \%$ dos híbridos de alta produtividade que superavam a média geral, empregando uma intensidade de seleção de $10 \%$ para cada localidade, ou $\mathrm{I}_{\mathrm{s}}>80 \%$ para grupos de localidades. Os fatores média geral por localidade e 0 coeficiente de variabilidade por localidade registrados no período de dez anos foram empregados como medidas auxiliares do valor preditivo de cada ambiente. Os autores encontraram diferenças entre localidades para todos os critérios de avaliação. As localidades de produtividade intermediária apresentaram altos valores dos estimadores da habilidade preditiva da performance média, comparadas com as localidades de baixa produtividade. 
Nenhuma das localidades estudadas satisfez o conjunto de critérios requeridos para ser considerada um sítio ideal de avaliação. Cinco localidades com alta produtividade foram escolhidas com base em cada critério de forma individual. Os autores concluíram que combinações de duas localidades poderiam ser empregadas para efetuar um screening preliminar dos híbridos, empregando uma intensidade de seleção intermediária. Uma predição mais precisa da performance média em um ano requereria a avaliação dos híbridos em um minimo de três a quatro locais previamente escolhidos. A estimação precisa da performance dos híbridos em mais de um ano requererá o teste dos híbridos nos locais escolhidos por seu elevado valor preditivo durante dois ou mais anos. Com uma finalidade semelhante Gauch \& Zobel (1997), desenvolveram uma pesquisa em milho procurando definir critérios relevantes para a avaliação da análise de mega-ambientes (mega-environments analyses), aplicando o modelo de efeitos principais aditivos e da interação multiplicativa. Os autores propõem uma série de estratégias para a identificação de mega-ambientes destacandose entre elas as seguintes: flexibilidade na manipulação dos dados de ensaios de produtividade que apresentam delineamentos diversos, concentração naquela parte da variação total que é relevante para a identificação de megaambientes, dualidade no proporcionamento de informação integrada a genótipos e ambientes e relevância do objetivo primário para indicar quais genótipos seriam eleitos para cada ambiente. Os resultados preliminares mostraram que um número pequeno e manejável de mega-ambientes, é na maioria das vezes, suficiente para aproveitar favoravelmente as interações e maximizar a produtividade. Os autores indicaram que para maximizar a produtividade das culturas em regiões heterogêneas, apesar das diferenças do ranking dos cultivares de um ambiente para outro, motivadas pela interação genótipo $x$ ambiente, seria necessária a subdivisão da área de cultivo em vários megaambientes homogêneos, identificando e cultivando genótipos adaptados para cada um destes mega-ambientes. 
Continuando com este enfoque Virk \& Mangat (1991), aplicaram dois testes para detectar a consistência através de localidades e anos das interações genótipo $x$ ambiente para o caráter produtividade de grãos em milheto pérola [Pennisetum typhoides (L.) R. Br.], empregando 13 cultivares, avaliados em 26 localidades e durante o decorrer de dois anos. O primeiro teste detectou mudanças significativas no posicionamento dos cultivares nas diferentes localidades e anos, envolvendo uma mudança direcional no ranking das médias de cinco cultivares. $O$ segundo teste comparando as diferenças na produtividade de 11 variedades e um híbrido avaliados em 26 localidades revelou diferenças significativas no ordenamento dos cultivares através de localidades para todas as entradas. Os autores concluíram que os dois testes empregados revelam a importância e necessidade de desenvolver cultivares de milheto com adaptação a ambientes específicos em lugar de produzir materiais de ampla adaptação.

Rosielle \& Hamblin (1981), compararam esquemas seletivos praticados sob ambientes não-estressantes e estressantes. Os autores desenvolveram equações para avaliar ambas as situações. Os resultados obtidos a partir da aplicação delas mostraram que a seleção para tolerância ao estresse resultava em uma redução da produtividade média. No entanto uma seleção para produtividade intermediária resultava num incremento da produtividade média em ambos os ambientes (estressantes e não-estressantes). Os resultados concordaram com a maioria dos trabalhos que verificaram uma correlação positiva entre o coeficiente de regressão para estabilidade e produtividades intermediárias.

Campbell \& Lafever (1977), testaram vários cultivares de trigo pão (Triticum aestivum L.) em nove localidades e durante três anos com o propósito de determinar a interação genótipo $x$ ambiente dos mesmos. Os autores estimaram os componentes de variância para cultivares $x$ localidades, cultivares $x$ anos e cultivares $x$ localidades $x$ anos. Eles comprovaram que a interação de 
cultivares com ambientes foi de importância considerável na determinação da produtividade relativa de cada cultivar. Também concluíram que na maioria dos programas de melhoramento ocorre certa seleção para adaptação específica, e que a localidade onde se pratica a seleção em gerações iniciais (Teste precoçe) possui a maior participação na determinação do grau de adaptabilidade do futuro cultivar. Finalmente, eles recomendam que os cultivares sejam testados por mais de um ano agrícola, e que não seria necessário prolongar os testes por mais de três anos, especialmente quando se empregam várias localidades por ano.

Uma das técnicas de avaliação da estabilidade genotípica que vem sendo utilizada com sucesso é a técnica de agrupamento de genótipos por similaridade com base numa análise multivariada. Os trabalhos detalhados a continuação permiten verificar isto.

Ghaderi et al. (1980), avaliaram 41 genótipos de trigo (Triticum aestivum L.) sendo sete deles cultivares e os 34 restantes linhas em processo de melhoramento, em oito localidades e durante dois anos. Os autores empregaram uma análise multivariada (Cluster) para agrupar genótipos de comportamento similar. Eles concluíram que este tipo de análise poderia ser de grande utilidade para selecionar as localidades a serem empregadas nos testes de gerações iniciais e para o desenvolvimento de genótipos com amplo ou reduzido grau de adaptabilidade. Também definiram 10 agrupamentos segundo sua similaridade quanto à produtividade. Finalmente, identificaram três categorias de genótipos de acordo a suas características de estabilidade.

Fox \& Rosielle (1982), utilizaram um conjunto de cultivares de trigo (Triticum aestivum L.) com o propósito de monitorar a interação genótipo $\mathrm{x}$ ambiente e classificar cada ambiente em relação ao caráter objetivo a ser introduzido. Técnicas de agrupamento por similaridade foram comparadas com a seleção baseada na performance média dos cultivares. $O$ agrupamento com 
base na similaridade foi superior ao estabelecido pela performance média dos cultivares.

Outro aspecto de importância a resaltar foi o fato de que numa serie de trabalhos realizados em diversas culturas, não foram detectadas interações genótipos $\times$ localidades, enquanto foram detectadas interações significativas genótipos $x$ anos. Entre tais trabalhos podem ser relacionados os seguintes: Rasmusson \& Lambert (1961) trabalhando com cevada (Hordeum vulgare L.), verificaram que os componentes de variância estimados para variedade $x$ ano $e$ variedade $x$ localidade $x$ ano foram significativos nos ensaios de produtividade, enquanto o componente variedade $x$ localidade não foi significativo.

Elgersma (1990), estudou o caráter produtividade de sementes em nove cultivares de ryegrass perene (Lolium perenne L.), em um esquema de plantas espaçadas. A variação genótipica dentro de cultivares para os componentes da produtividade e outros caracteres de importância agronômica foram registrados em quatro ambientes e empregando clones como repetições. $O$ autor detectou uma variação elevada dentro e entre cultivares para a maioria dos caracteres avaliados. Foram encontradas interações significativas cultivar $x$ ano para a maioria dos caracteres, enquanto não foram detectadas interações significativas cultivar $\times$ localidade.

Finalmente um outro tratamento da problemática foi abordado por vários autores. Basicamente suas pesquisas foram orientadas a avaliar a interação de vários caracteres quantitativos com 0 ambiente, empregando diversas metodologias para a abordagem da problemática.

Rasmusson \& Glass (1967), empregando duas populações derivadas de linhas $F_{3}$ de cevada (Hordeum vulgare $L$.), e avaliadas nas gerações $F_{5}, F_{6} \in F_{7}$, estimaram os componentes de variância, herdabilidade e ganho com seleção para sete caracteres avaliados. Os componentes de variância para a interação 
genótipo $\times$ localidade foram não significativos para todos os caracteres avaliados. As estimativas das interações de segunda ordem, $\sigma^{2}(G L A)$, foram de modo geral maiores quando comparadas com as de primeira ordem, tais como $\left.\sigma^{2}{ }_{(G L} L\right)$ e $\sigma^{2}{ }_{(G ~ A)}$. Por outro lado, as estimativas de herdabilidade foram mais altas para a data de florescimento (emissão da panícula) e poder diastásico (atividade enzimática de grande importância na elaboração de cerveja); intermediárias para cerosidade das espiguetas e altura da planta e baixas para produtividade.

Hadjichristodoulou (1989), calculou os coeficientes de correlação ambientais de todos os pares possiveis de combinações de cinco caracteres (produtividade de grãos, data de florescimento, número de perfilhos por metro quadrado, altura da planta e peso de mil grãos utilizando 30 cultivares de trigo duro (Triticum durum L.) e 30 cultivares de trigo pão (Triticum aestivum L.) cultivados em 18 ambientes. 0 caráter produtividade de grãos manifestou uma correlação significativa com o resto dos caracteres avaliados na maioria dos cultivares. O coeficiente de correlação médio para todos os cultivares de Triticum durum $L$. oscilou de 0,58 a $-0,83$, enquanto, no caso dos cultivares de Triticum aestivum L. esta correlação oscilou de 0,66 a 0,85 . Os coeficientes de correlação entre data de florescimento com o resto dos carateres foi também significativa, oscilando de $-0,45$ a $-0,79$ no caso dos cultivares de Triticum durum $L$., enquanto a oscilação para os cultivares de Triticum aestivum $L$. foi de 0,61 a $-0,85$. Por outro lado, os coeficientes de correlação entre número de perfilhos com altura da planta, e peso de 1000 grãos foram os menores, oscilando de 0,19 a 0,32 no caso dos cultivares de Triticum durum L., enquanto que a oscilação para os cultivares de Triticum aestivum $L$. foi de 0,39 a 0,60 . Também foram encontradas diferenças significativas entre genótipos com respeito aos coeficientes de correlação ambientais, e as mudanças associadas a um caráter foram o resultado de mudanças em outros caracteres. $O$ autor concluiu que as práticas agronômicas que favorecem um estabelecimento 
precoce e um bom estande de plantas da cultura em regiões áridas possuem um efeito favorável sobre os componentes da produtividade e dos caracteres adaptativos mais importantes, os quais contribuem em maior proporção para a obtenção de altas produtividades.

Yang \& Baker (1991) caracterizaram as interações genótipo $x$ ambiente em cinco caracteres quantitativos de dois cruzamentos entre trigos de primavera (Triticum aestivum L.). A partir de cada uma das 48 familias $F_{2}$ derivaram três linhas $F_{3}$, as quais foram avaliadas em $F_{5}$ (1986) e $F_{6}$ (1987), em um único local. Os autores empregaram um delineamento em parcelas subdivididas, avaliando os caracteres dias para florescimento, altura da planta, número de grãos por panícula, peso de grãos e resistência dos grãos à quebra. Eles detectaram variações significativas entre e dentro de famílias $F_{2}$ em ambos cruzamentos e para todos os caracteres avaliados. Foram também detectadas interações significativas famílias $x$ anos para todos os caracteres exceto para resistência à quebra dos grãos no primeiro cruzamento, e para os caracteres dias para florescimento, grãos por panícula e resistência à quebra dos grãos, no segundo cruzamento. Também detectaram interações significativas linhagem $x$ ano para o caráter resistência à quebra dos grãos, no segundo cruzamento. A interação detectada foi do tipo simples, e foi devido a heterogeneidade das variâncias. Os autores concluíram que as interações do tipo simples possuem um efeito pouco notável sob os esquemas seletivos, no entanto, as mesmas podem limitar seriamente a estimação de ligação e da epistase a partir das variâncias e covariâncias entre parentes.

Escribano et al. (1997), avaliaram vários caracteres de importância agronômica em 59 populações de feijão (Phaseolus vulgaris L.) cultivadas em diferentes ambientes. Os caracteres avaliados foram peso fresco, curvatura, quociente largura/comprimento e largura/espessura de vagens e sementes, textura, volume, dureza, absorção de agua, proteína crua, óleo, fibra crua, conteúdo de açúcares e amido das sementes. Os autores registraram 
interações significativas genótipos $\mathrm{x}$ ambientes para os caracteres peso fresco das vagens, quocientes largura/comprimento, largura/espessura e textura das vagens; e para peso seco, absorção de água, dureza e quocientes largura/comprimento e largura/espessura de sementes.

\subsection{METODOLOGIAS DISPONIVEIS PARA AVALIAR A INTERAÇÃO GENÓTIPO X AMBIENTE.}

A habilidade de um genótipo para reproduzir um comportamento através de diferentes locais e anos foi definida como estabilidade da performance genotípica. Alguns cultivares possuem uma adaptação ampla, crescendo em uma grande variedade de condições ambientais, enquanto que outros manifestam sua potencialidade produtiva só em alguns ambientes específicos. A estabilidade da performance de um cultivar através de diferentes ambientes é influenciada pelo genótipo das plantas individuais, e pelo grau de relacionamento genético das plantas de um mesmo cultivar. Os termos "homeostase" e "poder tampão" (buffering) têm sido empregados para descrever a estabilidade da performance de plantas individuais ou grupos de plantas crescendo em diferentes ambientes (Fehr, 1987).

Allard \& Bradshaw (1964), utilizaram os termos "homeostase desenvolvimentalista" (Developmental homeostasis) e "poder tampão individual" (Individual buffering) para definir a estabilidade das plantas individuais. Os autores demonstraram que os indivíduos heterozigotos, tais como híbridos $F_{1}$, eram mais estáveis que seus parentais homozigóticos, segundo eles, a maior estabilidade dos indivíduos heterozigóticos estaria relacionada a sua habilidade de se desenvolver melhor sob condições de 
estresse ambiental. Finalmente os autores definiram os termos "homeostase genética" e "poder tampão populacional" para descrever a estabilidade de um grupo de plantas. Os cultivares heterogêneos, de maneira geral, possuem em média uma maior estabilidade em relação dos cultivares homogêneos.

Um grande número de procedimentos estatísticos tem sido desenvolvidos e empregados para o entendimento e a avaliação das interações genótipo $x$ ambiente e seu relacionamento com a estabilidade genotipica, sendo as mesmas detalhadas a seguir:

- Análise da variância: A estabilidade ambiental de um grupo de genótipos neste caso particular é avaliada através de uma análise padrão (standard) da variância. A significância das interações envolvendo aos genótipos é determinada por meio de um teste $F$. A magnitude relativa dos componentes de variância das interações genótipo $x$ local, genótipo $x$ ano, e a interação tripla genótipo $x$ local $x$ ano são empregadas para determinar os efeitos de locais $e$ anos sobre a estabilidade de um grupo de genótipos.

- Análise da variância conjunta: A análise padrão da variância aplicada a um certo número de genótipos não permite a obtenção da informação a respeito da estabilidade ambiental dos genótipos individuais. Esta informação pode ser obtida efetuando uma análise da variância combinada para cada conjunto (pairwise combination) de genótipos em todos os locais e em um determinado ano. Para cada genótipo, poderá se calcular a média estimada da variância da interação genótipo $x$ local $\left(\sigma_{G L}^{2}\right)$, derivada a partir de sua combinação com todos os outros genótipos. Esta média proporciona uma medida da contribuição de cada genótipo à interação genótipo $x$ local. 
- Análise de regressão: A estabilidade ambiental dos genótipos individuais pode também ser calculada por meio de uma análise de regressão. Considerando um grupo de genótipos que é cultivado em um grande número de ambientes, torna possível o cálculo de um índice ambiental, que refletiria a performance média de todos os genótipos em cada local ou ano (ambiente). Posteriormente a performance de cada genótipo é submetida a regressão com o índice ambiental para se obter sua performance média em todos os ambientes, sua resposta linear aos ambientes variáveis, e um estimador dos desvios da regressão linear para cada ambiente. Eberhart \& Russel(1966), descreveram ao genótipo ideal como aquele que apresentava uma produtividade média alta, um coeficiente de regressão igual a 1.0, e os desvios da regressão iguais a 0 . Tal genótipo poderia ver incrementada sua performance na medida da melhoria do ambiente donde ele é cultivado.

- Análise geométrica: Neste caso particular a estabilidade genotípica é medida através dos desvios com respeito a produtividade esperada em todos os ambientes avaliados. Tais desvios definem as coordenadas de um genótipo dentro de um "espaço de estabilidade", que possui um número de dimensões equivalente ao número de ambientes de avaliação. A estabilidade genotípica é expressa como uma distância euclidiana entre um determinado genótipo e um genótipo estável (estabilidade relativa), ou também entre dois genótipos quaisquer (estabilidade comparativa).

- Análise de agrupamento (Cluster analysis): Esta metodologia é empregada para classificar a estabilidade genotípica com base nas similaridades do comportamento fenotipico nos diferentes ambientes de avaliação. Tal metodologia possui uma elevada eficiência para identificar grupos de genótipos com várias combinações de médias e estabilidade. 
Uma série de propostas e modificações às metodologias para avaliar a estabilidade foram sugeridas por alguns autores no percurso do tempo.

Verma et al. (1978), propuseram uma metodologia de análise da estabilidade baseada na aplicação de uma regressão bisegmentada. Segundo os autores o genótipo ideal é aquele aquele que associa alta capacidade produtiva, alta estabilidade, baixa sensibilidade às condições adversas dos ambientes desfavoráveis, mas que é capaz de responder satisfatoriamente a melhoria do ambiente. A metodologia prevê a estimativa de duas retas de regressão, uma abrangendo os ambientes inferiores e a outra os ambientes superiores. Esta metodologia foi aperfeiçoada por Silva \& Barreto, (1985).

Cruz et al. (1989), propuseram uma modificação da análise de estabilidade sugerida por Silva \& Barreto (1985). Para comparação, os autores aplicaram o modelo original e o modificado a um ensaio de produtividade de milho (Zea mays L.) onde foram testados 17 cultivares em 12 locais, no percurso dos anos 1982/83. Os autores observaram que o modelo modificado possuia algumas vantagens a respeito do modelo original destacando-se entre elas as seguintes: a computação das estimativas dos parâmetros e da soma de quadrados foi simplificada; os erros das estimativas foram menores; as correlações residuais entre os parâmetros de estabilidade de maior interesse estimados foram eliminadas. Esta última possibilitou uma melhor avaliação da correlação genética eventualmente presente entre os padrões de estabilidade para cada caráter.

Chaves et al. (1989), baseando-se na hipótese de que os efeitos de ambientes sobre os genótipos, na manifestação fenotípica de um caráter, ocorrem de forma multiplicativa, estudaram um modelo não linear, que é multiplicativo apenas em seus parâmetros genético e ambiental. Os autores 
utilizaram dados de produtividade de espigas de milho (Zea mays L.) para verificar a possível adequação do modelo não linear. Eles verificaram o seguinte: ambientes favoráveis, nos quais a média do caráter era maior, propiciaram melhor discriminação entre os genótipos ou cultivares; nas análises conjuntas usuais, a soma de quadrados de uma interação ficava dependente dos efeitos principais envolvidos; o ajuste de médias de tratamentos de diferentes ensaios, onde apenas algumas testemunhas eram comuns a todos eles, deverá ser feito por fatores multiplicativos, e não aditivos; - coeficiente de regressão linear, normalmente empregado na análise da estabilidade de cultivares, passará a ser positivamente correlacionado com a média geral das cultivares. Analisando 64 ensaios de milho, os autores encontraram que o modelo multiplicativo teve uma eficiência igual ou superior ao modelo linear; além disso, o efeito multiplicativo foi responsável, em média, por $11 \%$ da interação de genótipos com ambientes, variando de $10,2 \%$ a $16,8 \%$.

Annicchiarico (1997) comparou os modelos da regressão agrupada (Joint regression) e dos efeitos principais aditivos e interação multiplicativa (Additive Main effects and Multiplicative Interaction- AMMI), segundo sua capacidade para descrever os efeitos das interações genótipo x local (GL) e genótipo $x$ ambiente (GE) [Ambiente: combinações locais-estações do ano], registrados em termos das variâncias das estimativas da heterogeneidade das regressões genotípicas, e a soma das variâncias dos componentes da interação principais (PC: Principal components) significativos;.e segundo a repetibilidade das medidas da estabilidade genotípica através de locais. $O$ autor empregou as seguintes medidas para estabilidade: Coeficiente de regressão de Finlay \& Wilkinson's; distância Euclidiana a partir da origem da interação significativa dos eixos dos componentes principais, e os valores absolutos do score do componente principal 1 (PC1) para o modelo de efeitos 
principais aditivos e interação multiplicativa. O AMMI foi mais adequado em seis grupos de dados como descritor dos efeitos da interação genótipo $x$ ambiente e para quatro grupos de dados como descritor da interação genótipo $x$ local através de estações. Nas demais situações, ambos os modelos mostraram-se apropriados, provendo um ordenamento similar de locais e genótipos para os efeitos da interação genótipos $x$ locais (GL). Os modelos que descreveram adequadamente a interação genótipo x local através de estações, possuiram, geralmente, medidas de estabilidade que se manifestam como moderadamente repetiveis entre estações.

Sneller et al. (1997), empregaram diferentes estatísticas para avaliar a estabilidade genotípica em soja [Glycine max (L.) Merrill], e verificar sua repetibilidade. Os autores avaliaram nove estatisticas derivadas do modelo de efeitos principais aditivos e interação multiplicativa, coeficientes de regressão provenientes de análises que empregam índices ambientais baseados tanto em produtividade de grãos como em altura da planta, tais como: $S^{2}{ }_{\text {di, }} \sigma_{i}^{2}$ e $S(1)$. Os autores empregaram dados de produtividade de ensaios conduzidos durante oito anos com cultivares correspondentes ao grupo de maturação $V$. A interação genótipo $x$ ambiente foi significativa garantindo a realização dos análises de estabilidade. A partição da soma de quadrados da interação genótipo $x$ ambiente por meio do modelo de efeitos aditivos e das técnicas de regressão foi significativa, e todas as medidas de estabilidade encontraram diferenças significativas entre cultivares. A repetibilidade do ranking dos cultivares para $S_{\text {di, }}^{2} \sigma_{i}^{2}$ e $S(1)$, e para a maioría dos estatísticos derivados do modelo aditivo estimados em diferentes períodos de tempo foi baixa, indicando que os mesmos não podem ser empregados pelos melhoristas para selecionar com base no caráter estabilidade. 
Lin et al. (1986), tentaram esclarecer a aparente confusão no referente a diversidade de estatísticas empregadas para avaliar a estabilidade genotípica, e a relação destes com o agrupamento de genótipos em conjuntos ou "clusters", segundo sua similaridade quanto à resposta aos ambientes. Os autores compararam nove medidas de similaridade propostas por vários pesquisadores, e concluíram que infelizmente estas representam diferentes aspectos da estabilidade e nem sempre fornecem um panorama completo da resposta genotípica. Para eles a técnica de análise multivariada seria a mais apropriada. A vantagem dos métodos não-paramétricos deve-se ao fato das respostas características dos cultivares poderem ser tratadas qualitativamente, sem a necessidade de efetuar uma caracterização matemática. 


\section{MATERIAL E MÉTODOS}

\subsection{CARACTERIZAÇÃO DO MATERIAL GENÉTICO}

O material experimental consistiu em três populações (denominadas 1, 2 e 3) derivadas de cruzamentos biparentais de soja [Glycine max (L.) Merrill]. Cada população esteve composta de 60 linhagens homozigóticas aleatórias obtidas pelo método SSD (Single seed descent). Os cruzamentos que deram origem as três populações foram os seguintes: População 1: BR 80-14853 x PI165896; População 2: PI-123439 x PI-239235; e População 3: GAÚCHA x OC 79230. A seguir descrevem-se as origens $e$ as principais características agronômicas dos materiais empregados nos cruzamentos (Pimentel, 1991):

a)- OC-79230: Linhagem brasileira, proveniente da OCEPAR, com ciclo aproximado de 60 dias (florescimento), hábito de crescimento determinado, flor branca, semente amarela, pubescência cinza e hilo marrom.

b)- GAÚCHA: Cultivar brasileiro, com ciclo aproximado de 60 dias (florescimento), hábito de crescimento indeterminado, flor branca, semente amarela, pubescência e hilo marrom.

c)- BR 80-14853: Linhagem brasileira, proveniente da EMBRAPA-CNPSo, com ciclo aproximado para florescimento de 51 dias, hábito de crescimento indeterminado, flor roxa, semente verde, pubescência marrom e hilo preto. 
d)- PI-165896: Linhagem norte-americana, fornecida pelo Centro Nacional de Pesquisa de Soja (EMBRAPA-CNPSo), com ciclo aproximado de 47 dias para florescimento, hábito de crescimento determinado, flor roxa, semente preta, pubescência marrom e hilo preto.

e)- PI-239235: Linhagem norte-americana, fornecida pela EMBRAPACNPSo, com ciclo aproximado de 55 dias para florescimento, hábito de crescimento indeterminado, flor branca, semente amarela, pubescência e hilo cinza.

f)- PI-123439: Linhagem norte-americana, fornecida pela EMBRAPA-CNPSo, com ciclo aproximado de 51 dias para florescimento, hábito de crescimento determinado, flor roxa, semente amarela, pubescência e hilo cinza.

Na Tabela 1 são apresentadas as características botânicas e agronômicas dos seis genótipos de soja utilizados como parentais.

Tabela 1: Características botânicas e agronômicas dos seis genótipos de soja utilizados como parentais.

\begin{tabular}{cccccccc}
\hline & \multicolumn{8}{c}{ CARACTERÍSTICAS $^{*}$} \\
\cline { 2 - 8 } & $\begin{array}{c}\text { Hábito } \\
\text { crescimento }\end{array}$ & $\begin{array}{c}\text { Ciclo } \\
\text { Médio } \\
\text { (dias) }\end{array}$ & $\begin{array}{c}\text { Cor da } \\
\text { flor }\end{array}$ & $\begin{array}{c}\text { Cor da } \\
\text { Pubes- } \\
\text { cência }\end{array}$ & $\begin{array}{c}\text { Cor da } \\
\text { vagem }\end{array}$ & $\begin{array}{c}\text { Cor do } \\
\text { hilo }\end{array}$ & $\begin{array}{c}\text { Cor do } \\
\text { tegu- } \\
\text { mento }\end{array}$ \\
\hline OC-79230 & D & 157 & B & C & C & C & A \\
GAÚCHA & I & 158 & B & M & M & M & A \\
BR 80-14853 & I & 158 & R & M & M & P & V \\
Pl-165896 & D & 150 & R & M & M & P & P \\
Pl-239235 & I & 160 & B & C & C & C & A \\
PI-123439 & D & 150 & R & C & C & C & A
\end{tabular}

*: D: determinado; I: indeterminado; B: branca; R: roxa; C: cinza; M: marrom; P:preto; $A$ : amarelo e V: verde.

*: Número de dias para a maturidade. 


\subsection{CARACTERIZAÇÃO DO AMBIENTE:}

Os experimentos foram realizados em solo do tipo terra roxa estruturada série "Luiz de Queiroz" (Ranzani et al. 1966), na área experimental do Departamento de Genética da Escola Superior de Agricultura "Luiz de Queiroz", no município de Piracicaba, SP, situada a $22^{\circ} 42^{\prime} 30^{\prime \prime}$ de latitude sul, $47^{\circ} 38^{\prime} 00^{\prime \prime}$ de latitude oeste e a $537 \mathrm{~m}$ de altitude em relação ao nível do mar.

De acordo com a classificação climática de THORNTHWAITE para esta região, a fórmula climática resulta em C2rA'a', ou seja, clima úmido com pequeno déficit de água, megatérmico, e com vegetação o ano todo.

\subsection{DELINEAMENTO EXPERIMENTAL}

Os materiais foram avaliados durante três anos agrícolas, 1993/94, 1994/95 e 1995/96. As progênies eram oriundas de três populações, contendo cada uma delas três conjuntos com 20 progênies, totalizando 60 progênies.

Utilizou-se um delineamento em blocos casualizados modificado, com três repetições. A modificação consistiu no agrupamento dos tratamentos em conjuntos. Estes conjuntos foram distribuídos de forma aleatória em cada repetição. E necessário destacar que o número de repetições do conjunto três do ano de avaliação 1993/94 devido a falta de sementes apresentou duas repetições em lugar das três previstas, em todas as populações. $O$ experimento além das progênies dos cruzamentos, incluiu os parentais e cinco testemunhas (BILOXI, BOSSIER, IAC-12, BR 80-14887, IAC FOSCARIN-31 e IAS-5). Devido a falhas na germinação, e perda de plantas pós-emergência que determinaram 
uma severa redução no estande dos mesmos, foi considerada conveniente a exclusão destes materiais no momento de efetuar as análises estatísticas.

As parcelas experimentais foram constituídas por uma fileira de um metro de comprimento, com um espaçamento de 0,50 metros entre linhas. A densidade de semeadura foi de 30 sementes por metro linear, com desbaste para 17 plantas, após a germinação.

O preparo do solo constou de uma aração profunda e duas gradagens. A abertura dos sulcos de plantio e a adubação utilizando-se $300 \mathrm{~kg} / \mathrm{ha}$ da fórmula 4-20-20, foram realizadas simultaneamente, com um implemento adaptado para tal finalidade.

As datas de semeadura foram $22 / 11,09 / 12$ e $27 / 11$ para os anos 1993, 1994 e 1995 respectivamente. No momento da semeadura, que foi realizada manualmente, foi feito a inoculação das sementes com uma estirpe de Bradyrhizobium japonicum, pulverizando-se o sulco de plantio com uma solução do inoculante, seguida da semeadura e da cobertura dos sulcos. Sempre que necessário foi realizada a irrigação do campo experimental.

Foram realizadas também pulverizações, quando necessárias, para o controle de insetos mastigadores e sugadores, principalmente o percevejo verde (Nezara viridula (L.)) e a lagarta da soja (Anticarsia gemmatalis Hüber.).

Foram avaliados os seguintes carateres de interesse agronômico:

a)- Número de dias para o início do florescimento: Período que corresponde ao número de dias decorridos entre a semeadura e quando mais de $50 \%$ das plantas apresentavam flores. A determinação foi realizada por parcela em três repetiçōes. 
b)- Altura média das plantas da parcela $(\mathrm{cm})$, registrada no início do florescimento: Distância compreendida entre a base e 0 ápice da haste principal, nos primeiros dias do florescimento. Foram medidas cinco plantas por parcela em três repetições.

c)- Número de dias para maturidade: Período que corresponde ao número de dias decorridos desde a semeadura até quando aproximadamente $95 \%$ das vagens das plantas apresentarem-se maduras. A determinação foi realizada por parcela em três repetições.

d)- Altura média das plantas da parcela $(\mathrm{cm})$, registrada na maturidade: Distância compreendida entre a base e 0 ápice da haste principal, na época da maturidade. Foram medidas cinco plantas por parcela em três repetições.

e)- Acamamento: Avaliado na maturidade através de uma escala de notas visuais que varia de 1 a 5 , onde a nota 1 corresponde a uma parcela com todas as plantas eretas e a nota 5 a uma parcela com todas as plantas acamadas. A avaliação foi realizada por parcela em três repetições.

f)- Produção de grãos: Avaliada na maturidade através do peso dos grãos $(\mathrm{g})$ de cada parcela em três repetições.

Para as finalidades deste trabalho foi utilizado somente o caráter produção de grãos, devido ser este o caráter de maior importância agronómica e estar sujeito a um efeito ambiental elevado (baixa herdabilidade). 


\subsection{ANÁLISE ESTATÍSTICA}

3.4.1 ANÁLISE DE VARIÂNCIA INDIVIDUAL PARA CADA ANO DE AVALIAÇÃO E PARA CADA CONJUNTO DE PROGÊNIES

Para as anovas individuais de cada população e ano de avaliação, o esquema de análise individual é dado a seguir:

\begin{tabular}{lcccc}
\hline F.V. & GL & QM & $E(Q M)$ & $F$ \\
\hline REPETIÇÃO (R) & $R-1$ & $Q_{3}$ & & $Q_{3} / Q_{1}$ \\
PROGÊNIES (P) & $P-1$ & $Q_{2}$ & $\sigma^{2}+R \sigma^{2}$ & $Q_{2} / Q_{1}$ \\
RESÍDUO & $(R-1)(P-1)$ & $Q_{1}$ & $\sigma^{2}$ & \\
\hline
\end{tabular}

O modelo matemático empregado para as análises individuais foi o seguinte:

$$
Y_{i j}=\mu+t_{i}+r_{j}+e_{i j}
$$

Onde:

$Y_{i j}$ observação referente ao tratamento " $i$ " na repetição " $j$ ";

$\mu$ média geral;

$t_{i}$ : efeito aleatório de tratamentos (Linhagens ou progênies); $i=1,2,3, \ldots . . \mathrm{T}$;

$r_{j}$ : efeito aleatório de repetições; $j=1, \ldots . R$;

$e_{i j}:$ erro experimental associado à parcela $i j$. 
3.4.2 ANÁLISE DE VARIÂNCIA INDIVIDUAL PARA CADA ANO DE AVALIAÇÃO AGRUPANDO "C" CONJUNTOS

O esquema de análise é dado a seguir:

\begin{tabular}{lclll}
\hline F.V. & GL & QM & $E(Q M)$ & $F$ \\
\hline CONJUNTOS (C) & $C-1$ & $Q_{4}$ & & \\
REPETIÇÄO (R)/C & $C(R-1)$ & $Q_{3}$ & & $Q_{3} / Q_{1}$ \\
PROGENIES. (P)/C & $C(P-1)$ & $Q_{2}$ & $\sigma^{2}+R \sigma^{2}$ & $Q_{2} / Q_{1}$ \\
RESÍDUO/C & $C(R-1)(P-1)$ & $Q_{1}$ & $\sigma^{2}$ & \\
\hline
\end{tabular}

3.4.3 ANÁLISE DE VARIÂNCIA CONJUNTA PARA OS TRESS ANOS DE AVALIAÇÃO E PARA CADA CONJUNTO

O objetivo da anova conjunta foi registrar a interação das progênies (tratamentos) com os diferentes ambientes (anos). O esquema de análise é dado a seguir:

\begin{tabular}{lclll}
\hline \multicolumn{1}{c}{ F.V. } & GL & QM & $E(Q M)$ & $F$ \\
\hline ANOS(A) & $A-1$ & $Q_{5}$ & & \\
REPETIÇÃO(R)/A & $A(R-1)$ & $Q_{4}$ & & \\
PROGENIES (P) & $(P-1)$ & $Q_{3}$ & $\sigma^{2}+R \sigma^{2}$ TA $+R A \sigma^{2}$ & $Q_{3} / Q_{2}$ \\
PXA & $(A-1)(P-1)$ & $Q_{2}$ & $\sigma^{2}+R \sigma^{2}$ TA & $Q_{2} / Q_{1}$ \\
RESIDUO/A & A(R-1)(P-1) & $Q_{1}$ & $\sigma^{2}$ & \\
\hline
\end{tabular}


A análise conjunta dos diferentes conjuntos de cada cruzamento seguem um esquema hierárquico, baseado no seguinte modelo matemático:

$$
Y_{i j k}=\mu+t_{i}+a_{j}+(t a)_{i j}+e_{i j k}
$$

Onde:

$\mu$. média geral;

$t_{i \text { : }}$ efeito aleatório de tratamentos (Linhagens ou progênies);

$i=1,2,3, \ldots . . T$;

$a_{j}$ : efeito de anos; $A=1, \ldots . . A$;

(ta) $)_{i j}$ :efeito da interação tratamentos $\mathrm{x}$ anos;

$e_{i j k}$ : erro experimental associado à parcela $i j k$.

3.4.4 ANALISE DA VARIÂNCIA CONJUNTA E AGRUPADA PARA "C" CONJUNTOS

O esquema de análise conjunta e agrupada para $\mathrm{C}$ conjuntos é dado a seguir:

\begin{tabular}{lcccc}
\hline \multicolumn{1}{c}{ F.V. } & $\mathrm{GL}$ & $\mathrm{QM}$ & $\mathrm{E}(\mathrm{QM})$ & $\mathrm{F}$ \\
\hline CONJUNTO(C) & $(\mathrm{C}-1)$ & $\mathrm{Q}_{6}$ & & \\
ANOS (A)/C & $\mathrm{C}(\mathrm{A}-1)$ & $\mathrm{Q}_{5}$ & & \\
REPETIÇÃO(R)/AVC & $\mathrm{AC}(\mathrm{R}-1)$ & $\mathrm{Q}_{4}$ & & \\
PROGENIES(P)/C & $\mathrm{C}(\mathrm{P}-1)$ & $\mathrm{Q}_{3}$ & $\sigma^{2}+\mathrm{R} \sigma^{2} \mathrm{TA}+\mathrm{RA} \sigma^{2} T$ & $\mathrm{Q}_{3} / \mathrm{Q}_{2}$ \\
PXA/C & $\mathrm{C}(\mathrm{A}-1)(\mathrm{P}-1)$ & $\mathrm{Q}_{2}$ & $\sigma^{2}+\mathrm{R} \sigma^{2} \mathrm{TA}$ & $\mathrm{Q}_{2} / \mathrm{Q}_{1}$ \\
RESÍDUO/A/C & $\mathrm{AC}(\mathrm{R}-1)(\mathrm{P}-1)$ & $\mathrm{Q}_{1}$ & $\sigma^{2}$ & \\
\hline
\end{tabular}


3.4.5 ANÁLISE DOS COMPONENTES GENÉTICOS E FENOTÍPICOS DA INTERAÇÃO GENÓTIPOS X AMBIENTES (ANOS)

As magnitudes relativas dos componentes simples (a) e complexo (b) da interação foram determinados com base no procedimento apresentado por Vencovsky \& Barriga, (1992), isto é:

$$
\begin{aligned}
& \sigma_{\mathrm{PXA}}^{2}=a+b, \text { onde: } \\
& a=(1 / 2)\left(\sqrt{\sigma^{2} \mathrm{P}_{1}}-\sqrt{\sigma^{2} \mathrm{P}_{2}}\right)^{2}, \mathrm{e} b=\left(1-\mathrm{rG}_{12}\right) \times \sqrt{\sigma^{2} \mathrm{P}_{1} \times \sigma^{2} \mathrm{P}_{2}}
\end{aligned}
$$

onde: $\sigma^{2} \mathrm{P}_{1}$ e $\sigma^{2} \mathrm{P}_{2}$ referem-se as variâncias genéticas de progênies nos anos 1 e 2 , respectivamente.

$\mathrm{rG}_{12}$ refere-se à correlação genética entre as médias de progênies nos anos 1 e 2 .

$$
\mathrm{rG}_{12}=\frac{\operatorname{COV}_{\mathrm{GP}_{12}}}{\sqrt{\sigma^{2} \mathrm{P}_{1} \times \sigma^{2} \mathrm{P}_{2}}}
$$

onde: COVGP 12 refere-se à covariância genética entre as médias de progênies nos anos $1 \mathrm{e} 2$.

Com base nestas fórmulas foi possível o cálculo dos componentes da interação de dois em dois anos, para o cálculo dos componentes da interação tripla (implicando os três anos de avaliação). Utilizou-se a equação proposta por Cockerham,(1963):

$$
\sigma_{\mathrm{PXA}(123)}^{2}: \mathrm{a}+\mathrm{b}: \sum\left[(1 / 2)\left(\sqrt{\sigma^{2} \mathrm{P}_{1}}-\sqrt{\sigma^{2} \mathrm{P}_{2}}\right)^{2}+\left(1-\mathrm{rG}_{12}\right) \times \sqrt{\sigma^{2} \mathrm{P}_{1} \times \sigma^{2} \mathrm{P}_{2}}\right] / A
$$


onde: $\sigma_{\text {PXA(123) }}^{2}$ corresponde à interação tripla progênies $x$ anos, envolvendo os três anos de avaliação, e A: anos de avaliação.

Para a estimação dos componentes fenotípicos utilizaram-se as mesmas fórmulas empregadas no cálculo dos componentes genéticos, substituindo as variâncias genéticas (progênies e interação) pelos respectivos quadrados médios. Ademais neste caso particular foram calculadas as correlações fenotípicas entre médias de progênies em lugar das genéticas.

Com base nestes resultados foram interpretados os componentes da interação e sua implicação com a seleção de genótipos superiores. Em uma primeira fase o objetivo foi detectar a predominância de uma interação do tipo simples, na qual a posição ou "ranking" das progênies conserva a mesma tendência nos diferentes anos de avaliação (Figura 1-A), ou se essa interação é do tipo complexa, na qual o ranking das progênies, ou posicionamento relativo das mesmas, vê-se alterado nos diferentes anos de avaliação (Figura 1-B). Finalmente em uma segunda fase foram estudadas as implicações deste tipo de interações no melhoramento genético da soja. 
A

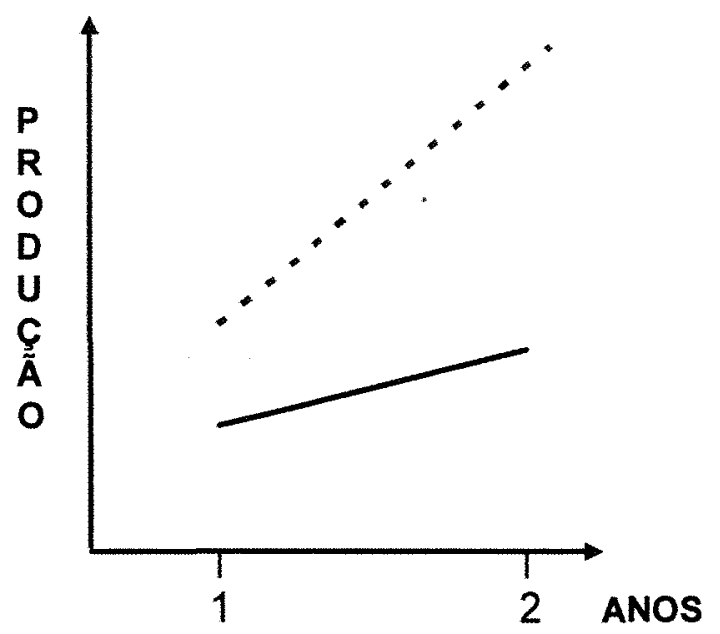

B

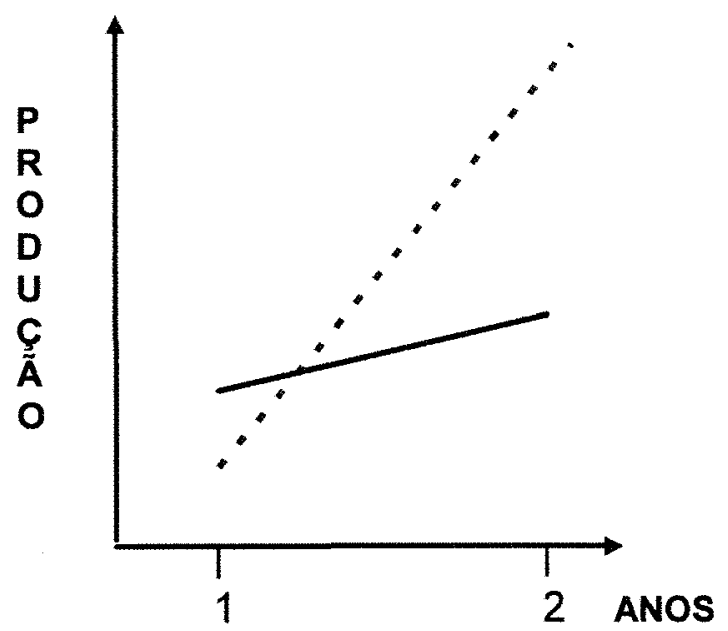

- . - PROGÊNIE X

- PROGÉNIE $Y$

Figura 1: Esquemas representativos da interação simples (A) e complexa (B). 


\section{RESULTADOS E DISCUSSÃO}

$\mathrm{Na}$ Tabela 2 são apresentados os valores das médias para o caráter produção de grãos, para as três populações $(1,2$ e 3$)$, envolvendo os três anos de avaliação. Em média a população 3 foi a que exibiu o maior valor $(212,5$ g/parcela), seguida da população 1 (195,6 g/parcela), sendo finalmente a população 2 a de menor produtividade média (180,3 g/parcela). Destaca-se pois a população 3 como a geradora de progênies de maior produtividade média, isto pode ser visto com maior clareza na Figura 2. A tendência geral foi uma maior produção das progênies de cada população no ano 1995/96, seguida do ano 1993/94 apresentando o ano 1994/95 a menor produtividade média (Figura 2).

Considerando os parentais que foram empregados para dar origem as três populações foi possivel formular algumas considerações de interesse para o melhoramento genético da cultura de soja. E conveniente lembrar que os parentais que deram origem as populações em estudo foram BR 80-14853 x PI165896 (população 1, semi-exótica: 50\% material exótico); PI-123439 x PI239235 (população 2, exótica: 100\% material exótico); e GAÚCHA x OC 79230 (população 3, adaptada: 100\% material adaptado). Levando em consideração os valores médios para produtividade de grãos detalhados acima, é possivel observar que o cruzamento que envolvía somente materiais adaptados (GAÚCHA x OC 79230), foi o que deu origem as progênies mais produtivas (212,5 g/parcela). Isto deve-se a que estes materiais vem de um processo anterior de seleção para produtividade, concentrando maior número de genes para produção de grãos. Por outro lado, a população 2 gerada a partir do cruzamento de dois materiais exóticos (PI-123439 x PI-239235), foi a de menor produtividade média (180,3 g/parcela). Isto é devido a que estes materiais 
provavelmente tem recibido uma seleção menos intensa para produtividade de grãos, concentrando um menor número de alelos para produtividade em relação aos materiais anteriores. Também é necessário destacar que a diferença de produtividade entre progênies provenientes de material adaptado em relação as de material exótico não foi muito grande (32.2 g/parcela: $15 \%)$. Por último, a população 3 originada a partir do cruzamento de um material adaptado por outro exótico (BR 80-14853 x PI-165896), manifestou uma produtividade intermediária (195,6 g/parcela), consequência da concentração diferencial de genes para produtividade presentes em ambos os materiais que deram origem as progênies desta população. Sem uma avaliação crítica, somada à falta de estimação de outros parâmetros genéticos, o melhorista poderia sentir-se tentado a utilizar somente material adaptado para dar origem a suas populações para fins de melhoramento. Para ter uma visão mais clara da problemática é necessário anexar a informação das variâncias genéticas entre progênies, calculadas para cada população (Tabela 24). Nesta tabela é possivel verificar que á população 1 proveniente do cruzamento de um material adaptado por outro exótico, foi a que teve o maior valor da variância genética $\left(1862,8 \mathrm{~g} /\right.$ parcela $\left.{ }^{2}\right)$, seguida das populações $3\left(1363,1 \mathrm{~g} /\right.$ parcela $\left.^{2}\right)$, e a população $2\left(637,3 \mathrm{~g} /\right.$ parcela $\left.^{2}\right)$, respectivamente (média dos três anos). Indicando isto que o cruzamento adaptado $x$ exótico foi o que liberou a maior variabilidade genética, porém para os fins de melhoramento deve-se considerar como o mais indicado, levando em conta que ao possuir uma variância genética maior, o progresso esperado com seleção será também superior. Mas sem dúvida a principal vantagem deste tipo de cruzamento (adaptado x exótico) fundamenta-se nos esquemas de ampliação da base genética da cultura da soja, seriamente erosionada pela aplicação de esquemas seletivos rigorosos visando prioritariamente a produção de grãos. Neste sentido, este tipo de cruzamento além de visar o incremento da produtividade da cultura, possibilita a incorporação de genes responsáveis por tolerância a agentes estressantes de origem biótico (doenças e pragas), e 
abiótico, (seca, salinidade, acidez, toxidez por alumínio, frio, calor, etc.) e do complexo gênico que determina as características adaptativas. Somado a isto, também se apresentam como uma das principais soluções para contornar os "patamares de produtividade" registrados nos programas de melhoramento para esta cultura, motivados por uma diminuição progressiva da variabilidade genética. Finalmente a diferença de produtividade das populações $3(212,5$ g/parcela) e 1 (195,6 g/parcela), foi apenas de $16,9 \mathrm{~g} /$ parcela ou $8 \%$, o que somado as vantagens indicadas anteriormente contribui para reforçar as tentativas destinadas a preservação e ampliação da base genética da cultura.

Na Tabela 2 são também apresentados os valores dos coeficientes de variação experimental para as três populações, ditos valores oscilaram em média, desde $19,69 \%$ para a população 1 , até $16,99 \%$ para a população 2 , correspondendo a população 3 um valor intermediário (17,35\%). De modo geral, os coeficientes de variação experimental oscilaram entre valores que podem ser indicativos de uma boa precisão experimental com este tipo de parcela.

Nas Figuras 3, 4 e 5 são apresentados os histogramas das médias das 60 progênies dos três anos de avaliação (1993/94, 1994/95 e 1995/96), para o caráter produção de grãos, relativos as três populações. Nas mesmas é possível observar uma distribuição normal da produtividade das progênies das três populações, propria de um caráter quantitativo como a produção de grãos.

Nas Tabelas 3, 4, 5, 6, 7, 8, 9, 10 e 11 são apresentados o resultados das anovas individuais (agrupando três conjuntos) para o caráter produção de grãos, efetuadas nas três populações, envolvendo os três anos de avaliação. A variação no número de graus de liberdade deve-se à ocorrência de parcelas perdidas $e$ ao número diferente de repetições das linhagens dos três cruzamentos. De modo geral foram detectadas diferenças altamente 
significativas $(p<0,01)$ entre progênies dentro de conjuntos, em todas as populações e em todos os anos de avaliação, indicando que pelo menos uma delas difere das demais. Foram também detectados efeitos significativos de conjuntos, e de repetições dentro de conjuntos para todas as populações em alguns dos anos de avaliação. Observou-se uma homogeneidade dos quadrados médios dos resíduos de cada ano de avaliação, nas três populações $(2439,69,1268,16$, e 965,$24 ; 871,02,1023,17$, e 910,$03 ; 1977,21,1120,69$, e 1051,99 para as populações 1, 2 e 3, e para os anos 1993/94, 1994/95 e 1995/96, respectivamente). Isto possibilitou a realização das anovas conjuntas.

No que refere-se às anovas conjuntas, a interação progênie $x$ ano foi altamente significativa $(p<0,01)$ para todas as populações $e$ todas as combinações binárias estabelecidas, assim como também para a combinação tripla envolvendo os três anos de avaliação. Também foram detectados efeitos significativos de conjuntos, anos dentro de conjuntos, e progênies dentro de conjuntos em todas as populações, e para a maioria das combinações de anos de avaliação (Tabelas 12, 13, 14, 15, 16, 17, 18, 19, 20, 21, 22 e 23).

A Tabela 24 mostra os valores da variância genética entre progênies $\left(\sigma^{2} P\right)$, estimados para as três populações (média dos três anos). Os valores calculados foram os seguintes: 1862,8 (g/parcela) ${ }^{2}$ para a população $1,637,3$ $(\mathrm{g} / \text { parcela })^{2}$ para a população 2 , e 1363,1 (g/parcela) $)^{2}$ para a população 3 . Os valores calculados para as variâncias genéticas entre progênies são semelhantes aos encontrados por Prado (1994), porém algo menores. Este autor empregando progênies dos cruzamentos OC-79230 x BR 80-8858; BR 808858 x BR 80-14853; BR 80-14853 x PI-165896; e BR 80-14853 x PI-239235, estimou os seguintes valores: 2143,$7 ; 2721,2 ; 1544,6$; e 2542,0 (g/parcela) $^{2}$ respectivamente. 
$\mathrm{Na}$ Tabela 25 são apresentados os valores da variância genética da interação de progênies $x$ anos $\left(\sigma^{2}\right.$ PXA $)$, também estimados para as combinações de dois e três anos. Os valores calculados para a combinação de três anos foram os seguintes, 944,4 (g/parcela $)^{2}$ para a população $1 ; 341,3(\mathrm{~g} / \text { parcela })^{2}$ para a população 2; e 931,9 (g/parcela) $)^{2}$ para a população 3 .

A Tabela 26 mostra os valores das covariâncias genéticas entre progênies (média de três conjuntos), determinadas para cada população e ano de avaliação.

No que refere-se as correlações genéticas entre progênies nos diferentes anos e para as três populações (Tabela 27) observou-se que em média a população 1 apresentou uma correlação superior entre as médias de suas progênies nos três anos de avaliação $(0,57)$, seguida da população $2(0,45)$, apresentando a população 3 a correlação mais baixa $(0,36)$. No caso das correlações fenotípicas entre as médias das progênies nos diferentes anos e para as três populações observou-se que em média a população 1 apresentou uma correlação superior entre as médias de suas progênies nos três anos de avaliação $(0,38)$, seguida da população $3(0,31)$, apresentando a população 2 a correlação mais baixa $(0,26)$. De modo geral pode-se observar que as correlações entre médias foram baixas e bastante uniformes para todas as populações avaliadas o que indica uma significativa interação das progênies com anos especificos (Tabela 28). As implicações do predomínio do componente complexo da interação nos esquemas de seleção serão explicadas em detalhe mais adiante.

$\mathrm{Na}$ estimação dos componentes genéticos observou-se um amplo predomínio do componente complexo, tanto nas combinações binárias ( 2 anos), 
quanto na interação dos três anos. Nesta última, o componente complexo representou $93,4 \%$ da interação na população 1 , restando apenas $6,6 \%$ para o componente simples, na população 2 estas proporções foram de $96,2 \%$ e $3,8 \%$, finalmente na população 3 as proporções foram de $83,2 \%$ e $16,8 \%$, respectivamente (Tabela 29 ).

A semelhança do acontecido com os componentes genéticos, no cálculo dos componentes da interação fenotípicos observou-se também um predomínio do componente complexo, mas ligeiramente mais pronunciado, sobretudo nas combinações binárias ( 2 anos), sendo menos notória essa diferença na interação dos três anos, exceto para a população 3 onde detectou-se um significativo aumento do componente complexo. O componente complexo representou $97,1 \%$ da interação na população 1 , restando apenas $2,9 \%$ para o componente simples, na população 2 estas proporções foram de $98,7 \%$ e 1,3\%, finalmente na população 3 as proporções foram de $92,3 \%$ e $7,7 \%$, respectivamente (Tabela 30 ).

Com a finalidade de explicar as implicações do predomínio do componente complexo da interação sob os esquemas seletivos praticados no transcurso dos programas de melhoramento, simulou-se a aplicação de uma intensidade de seleção de $10 \%$, nas três populações avaliadas (seis progênies superiores selecionadas por população). Os resultados podem ser vistos nas Tabelas 31 (população 1), 32 (população 2), e 33 (população 3). É possível ver que nenhuma das progênies repetiu sua performance nos três anos, o qual demonstra que a aplicação de uma intensidade de seleção do $10 \%$ no primeiro ano de avaliação (1993/94), em qualquer das três populações descartaria progênies que sob outras condições ambientais especificas, como as acontecidas nos anos seguintes (1994/95 e 1995/96), teriam um grande 
potencial produtivo, o mesmo raciocínio é válido para a seleção praticada nos demais anos.

Para exemplificar essa situação recorremos aos dados das Tabelas 31,32 e 33. Aplicando uma intensidade de seleção de $10 \%$ nas três populações e nos três anos de avaliação, resulta evidente que apenas as progênies $4 \mathrm{da}$ população 1 e a progênie 21 da população 2 seriam selecionadas nos três anos de avaliação. $O$ resto das progênies poderia ser descartado em função de não possuírem uma boa interação com as condições ambientais específicas presentes no ano em que é praticada a seleção, desse modo progênies tais como a 17 e 11 da população 1 , e a progênie 12 da população 2 , seriam descartadas no primeiro ano de avaliação (1993/94), sendo que as mesmas tiveram uma excelente performance nos dois anos seguintes (1994/95 e 1995/96). Como pode ser visto a interação complexa complica o processo seletivo, fazendo necessária a realização de avaliações adicionais, em várias localidades e anos, com a finalidade de contornar essas complicações. Essa situação pode ser observada com maior clareza nas Tabelas 31,32 e 33.

Como foi dito, as alternativas para contornar esta dificuldade consistem basicamente na avaliação dos materiais em várias localidades e anos. Levando em conta isto, foi simulado um esquema seletivo baseado no comportamento médio das progênies nos três anos de avaliação, selecionando-se $10 \%$ das progênies superiores de cada população. Sem dúvida este é o critério mais racional, pois o mesmo contempla aquelas progênies que tiveram um desempenho médio mais estável durante o transcurso dos três anos de avaliação. Os resultados da aplicação deste esquema seletivo nas três populações em estudo (1, 2 e 3 ), podem ser vistos nas Tabelas 34,35 e 36 . De modo geral, a seleção com base nas médias das progênies nos três anos de avaliação possibilitou a retenção das progênies mais produtivas das populações em estudo. 
Estes resultados concordam com os encontrados por vários pesquisadores trabalhando com diversas culturas. Misevic \& Dumanovic (1989), realizando pesquisas em milho (Zea mays L.) com a finalidade de escolher ambientes considerados preditivos da performance de um grande número de híbridos, determinaram que seriam necessárias avaliações dos materiais em dois ou mais ambientes considerados preditivos e durante um período de dois ou mais anos, aplicando intensidades de seleção intermediárias para garantir a seleção dos híbridos segundo sua performance produtiva. Resultados semelhantes foram encontrados por Aguiar et al. (1989), os autores avaliaram 400 progênies de meios-irmãos de milho provenientes da população CMS-39 em três localidades, durante um ano agrícola, constatando que a estimativa da variância da interação progênies $x$ ambientes foi relativamente alta, indicando $a$ necessidade das progênies serem avaliadas em mais de um ambiente. $O$ desdobramento da interação progênies $x$ locais mostrou que ela é devida, em grande parte, à falta de correlação entre o desempenho das progênies nos vários locais.

Por outro lado, Mebrahtu \& Elmi (1997), utilizando a técnica de análise de estabilidade genotípica por meio da regressão, com a finalidade de obter uma ferramenta auxiliar no esquema de seleção de parentais para hibridação em um programa de soja para consumo humano; e empregando uma análise da variância combinada para os três anos, detectaram variações significativas entre anos para os caracteres avaliados. Também detectaram uma interação significativa genótipo $\mathrm{x}$ ano para os caracteres avaliados, indicando que os genótipos não manifestaram estabilidade de um ano para outro. Os autores concluíram que seriam necessários vários anos de avaliação para poder determinar com precisão o potencial genético dos genótipos analisados. 
Finalmente, com a finalidade de se detectar quais eram as progênies que exibiam uma maior interação com 0 ambiente, as 60 progênies das três populações foram subdivididas em grupos de 20 progênies, com base na sua produtividade em cada ano de avaliação, resultando assim na definição de três grupos de progênies (superiores, intermediárias e inferiores). Para estabelecer isso foi necessário o cálculo da oscilação das médias de cada categoria, nos três anos, e para cada população. Observou-se de modo geral que as progênies de maior produtividade possuem uma maior oscilação nas suas médias, seguidas das progênies de produtividade intermediária, enquanto que as progênies de baixa produtividade apresentaram uma oscilação muito pequena. As oscilações médias na população 1 , foram $15,6 \%$ para as progênies superiores, $10,6 \%$ para as progênies intermediárias, e 5,8\% para as progênies inferiores. $\mathrm{Na}$ população 2 estes valores foram $8,1 \%, 3,8 \%$ e $2,8 \%$, respectivamente. Finalmente na população 3 os valores foram $14,5 \%, 14,9 \%$ e $7,3 \%$. Esta última população manifestou um pequeno desvio da tendência geral devido às progênies superiores e intermediárias apresentarem oscilações semelhantes. Esse comportamento pode se apreciar com maior clareza nas Tabelas 37, 38, e 39, e nas Figuras 6,7 e 8 .

O fundamento genético deste comportamento diferencial das progênies de diferente nível de produtividade, pode ser entendido do seguinte modo: As progênies de produtividade superior concentram um número maior de poligenes ou genes menores para produtividade de grãos, cada um deles possuindo um efeito ambiental próprio, a somatória destes efeitos ambientais individuais determina um efeito ambiental conjunto que vai ser sempre superior ao efeito conjunto das progênies de produtividade intermediária que possuem um menor número de poligenes, e portanto um menor efeito ambiental conjunto ou acumulado. O mesmo raciocínio pode ser aplicado quando são comparadas as progênies de produtividade intermediária com as de produtividade baixa (Falconer \& Mackay, 1996). Por outro lado, as progênies superiores possuem 
uma combinação de genes, "arranjo gênico", que codificam para uma série de características tais como uma maior eficiência fotossintética, maiores taxas de assimilação de nutrientes, partição de fotoassimilados para as vagens, período de enchimento de grãos, etc., características que contribuem para acrescentar a dependência por ambientes altamente produtivos, ou seja, aqueles ambientes que podem satisfazer as elevadas demandas agroecológicas das progênies produtivas [disponibilidade de água, luz, e nutrientes em quantidade e qualidade; (Apel, 1984; Vose, 1984)]. Quando estas condições são satisfeitas as progênies manifestam toda sua potencialidade produtiva, enquanto que quando estas exigências não são satisfeitas em sua totalidade, ou não se encontram presentes, as progênies não expressam toda sua produtividade, manifestando oscilações em seu desempenho de um ambiente para outro, tais como as que foram observadas no presente trabalho. Finalmente, existe ainda outra explicação para este fenômeno: no melhoramento da soja, assim como também em outras culturas, deu-se um ênfase excessivo para o caráter produtividade de grãos, aplicando-se esquemas seletivos intensos e nem sempre criteriosos, determinando um forte estreitamento da base genética da cultura. Este processo motivou a perda de um grande número de genes tais como aqueles responsáveis pela tolerância a estresses do tipo biótico (doenças e pragas), e abiótico, (seca, salinidade, acidez, toxidez por alumínio, frio, calor, etc.) e do complexo gênico que determina as características adaptativas. Todos estes fatores contribuiram para que a cultura tivesse uma dependência por ambientes altamente produtivos, somado a uma falta de "homeostase ambiental", ou seja a presença de um ou mais fatores estressantes (bióticos e abióticos) determina uma significativa redução da produtividade da cultura. Essa redução sempre é maior nas linhagens mais produtivas pois estas acumulam um maior número de genes para produtividade em detrimento dos genes que determinam tolerância a estresses bióticos e abióticos, assim como os responsáveis por caracteres adaptativos (National Research Council, 1972). 
Nas Figuras $9,10,11,12,13$ e 14 estão representadas as seis progênies das três populações que apresentaram maior "homeostase fenotípica", e as seis que apresentaram uma reduzida "homeostase fenotípica", no percurso dos três anos de avaliação (1993/94, 1994/95 e 1995/96).

Algumas particularidades podem ser destacadas no referente ao comportamento das progênies. Por exemplo, na população 1, as progênies $4 \mathrm{e}$ 11 apresentaram um comportamento excepcional, pois além de serem altamente produtivas, apresentaram uma considerável estabilidade ao longo dos anos, indicando isto que as mesmas possuem uma adaptabilidade a diversas condições ambientais, sendo estes materiais altamente recomendáveis, especialmente quando pretende-se liberar materiais de ampla distribuição (Figura 9). Por outra parte, as progênies 16 e 17 da mesma população apresentam um comportamento contrastante, a progênie 16 manifestou uma alta produtividade no ano 1993/94 enquanto que no ano 1994/95 seu desempenho foi insatisfatório, o mesmo comportamento manifestaram as progênies 55 e 30 . Já a progênie 17 manifestou um fraco desempenho no ano 1993/94, sendo muito bom seu comportamento no ano 1995/96.

$\mathrm{Na}$ população 2 , as progênies 14 e 29 manifestaram uma alta produtividade somada a uma relativamente alta estabilidade. As progênies 33 , 31 e 38 manifestaram um comportamento não estável, apresentando um bom desempenho no ano 1993/94, enquanto que no ano 1994/95 seu desempenho foi fraco. Por outro lado as progênies 24 e 41 manifestaram uma baixa produtividade no ano 1993/94 e uma alta produtividade no ano 1995/96.

Finalmente na população 3 , as progênies 3 e 37 mostraram um bom desempenho, somado a uma relativamente alta estabilidade. A progênie 7 manifestou uma alta produtividade no ano 1993/94, enquanto que seu desempenho foi fraco no ano 1995/96. Por outro lado as progênies 29,36 e 57 
tiveram um fraco comportamento no ano 1993/94, mas seu desempenho no ano 1995/96 foi muito bom.

Com base nestes resultados é possivel formular algumas considerações: como foi indicado anteriormente aquelas progênies que manifestam uma alta produtividade somada a uma elevada estabilidade podem ser recomendadas para serem cultivadas em uma ampla área geográfica, pois elas possuem uma adaptabilidade que pode ser considerada como geral. Esta é uma situação ideal, mas nem sempre se cumpre. Tal como pode ser notado no presente trabalho, apenas umas poucas progênies altamente produtivas manifestaram este comportamento. De fato, a tendência observada foi a inversa, ou seja, as progênies altamente produtivas mostraram uma baixa estabilidade. Por outro lado, a maioria das progênies comportou-se bem em alguns ambientes (anos), enquanto que em outros anos sua performance produtiva foi fraca. Neste caso fica evidente o elevado grau de dependência por ambientes específicos que as mesmas possuem, produto de sua elevada interação genótipo $x$ ambiente. Numa situação destas o melhorista vê-se forçado a avaliar a capacidade de adaptação específica dos genótipos, recomendando materiais para serem cultivados em áreas restritas, sob condiçōes ambientais determinadas, como por exemplo, de alto emprego de insumos produtivos (água, adubos e agroquímicos). A interação genótipo $x$ ambiente nem sempre tem que ser vista como algo negativo, um entendimento correto da mesma possibilita ao melhorista obter vantagens produtivas através do desenvolvimento de materiais adaptados a regiões específicas. Finalmente fica claro que na presença de uma forte interação genótipo $x$ ambiente a aplicação de uma intensidade de seleção muito alta num determinado ano, pode representar a perda de muitas progênies que em outros anos, sob outras condições ambientais, poderiam possuir um bom desempenho. E recomendável sob estas circunstâncias a aplicação de intensidades de seleção intermediárias e a avaliação das progênies em vários 
locais em um período igual ou maior a três anos. Este último acaba retardando o programa de melhoramento pois o ganho por seleção vê-se reduzido. Basicamente esta redução deve-se à menor intensidade de seleção aplicada, e ao maior número de anos necessários para completar um ciclo seletivo. 


\section{CONCLUSÕES}

Com base nos resultados do presente trabalho é possível concluir o seguinte:

a)- Das três populações avaliadas a população 3 foi a que mostrou-se como a produtora de progênies de maior produtividade média nos três anos de avaliação, seguida das populações 1 e 2 respectivamente. $O$ cruzamento que deu origem a população 1 (adaptado $x$ exótico) pode ser considerado como 0 mais adequado para fins de melhoramento devido ao mesmo liberar maior variabilidade genética e produzir progênies produtivas com base genética ampla.

b)- Detectou-se uma interação genótipos $x$ ambientes (progênies $x$ anos) altamente significativa para todas as populações avaliadas. $A$ análise dos componentes da interação fenotípicos e genéticos mostrou que o componente complexo da mesma foi predominante em alto grau.

c)- $O$ esquema seletivo baseado na média das progênies nos três anos de avaliação demonstrou ser o critério mais racional, pois o mesmo contempla aquelas progênies que tiveram um desempenho médio mais estável durante o decorrer dos três anos de avaliação. De modo geral, a seleção com base nas médias das progênies nos três anos de avaliação possibilitou a retenção das progênies mais produtivas das populações em estudo. $\grave{A}$ aplicação de uma intensidade de seleção muito alta em um determinado ano, pode representar a perda de muitas progênies promissoras, sendo recomendável, sob tais 
circunstâncias, a aplicação de intensidades de seleção baixas inicialmente, para gradativamente identificar as progênies superiores.

d)- As progênies de maior produtividade apresentaram uma maior oscilação nas suas médias, seguidas das progênies de produtividade intermediária, enquanto que as progênies de baixa produtividade apresentaram uma oscilação muito pequena. 


\section{REFERÊNCIAS BIBLIOGRÁFICAS:}

AGUIAR, P. A.; RAMALHO, M. A P.; MAGNAVACA, R.; ANDRADE, M. A. Avaliação de progênies de meios irmãos da população de milho CMS-39 em diferentes condições de ambiente. Pesquisa Agropecuária Brasileira, v. 24, $N^{\circ}$ 6, p. 727-732, 1989.

ALTMAN, D. W.; STIPANOVIC, R. D.; BENEDICT, J. H. Terpenoid aldehydes in upland cottons. II. Genotype-Environment interactions. Crop Science, v. 29, p.1451-1456, 1989.

ALLARD, R. W. Principios do melhoramento genético das plantas. USAID. Rio de Janeiro, 1971. $381 \mathrm{p}$.

ALLARD R. W.; BRADSAW, A. D. Implications of genotype-environmental interactions in applied plant breeding. Crop Science, v. 4, p.503-508, 1964.

ANNICCHIARICO, P. Joint regression vs AMMI analysis of genotypeenvironment interactions for cereals in Italy. Euphytica, v. 94, p. 53-62, 1997.

APEL, P. Photosynthesis and assimilate partitioning in relation to plant breeding. In: Crop Breeding a contemporary basis. Vose \& Blixt Editors. Oxford, 1984, Chapter 7, p. 163-184. 
BATIONO A.; CHRISTIANSON, C. B.; BAETHGEN, W. E.. Plant density and nitrogen fertilizer effects on pearl millet production in Niger. Agronomy Journal, v. 82, p. 290-295, 1990.

BRANCH, W. D.; KIRBY, J. S.; WYNNE, J. C.; HOLBROOK, C.C.; ANDERSON, W. F. Sequential vs. Pedigree selection method for yield and leafspot resistance in peanut. Crop Science, v. 31, p.274-276, 1991.

BROWN L. G.; HOVELAND, C. S; KARNOK, K. J. Harvest management effects on alfalfa yield and root carbohydrates in three Georgia environments. Agronomy Journal, v. 82, p. 267-273, 1990.

CAMPBELL, L. G; KERN, J.J. Cultivar $x$ environment interaction in sugarbeet yield trials. Crop Science, v. 22, p.932-935, 1982.

CAMPBELL, L. G; LAFEVER, H. N. Cultivar $x$ environment interaction in soft red winter wheat yield tests. Crop Science, v. 17, p.604-608, 1977.

CARAVETTA G. J.; CHERNEY, J. H.; JOHNSON, K. D. Within-row spacing influences on diverse sorghum genotypes: I. Morphology. Agronomy Journal, v. 82, p. 206-210, 1990.

CHAVES, L. J.; VENCOVSKY, R.; GERALDI, I. O. Modelo não-linear aplicado ao estudo da interação de genótipos $x$ ambientes em milho. Pesquisa Agropecuária Brasileira, v. 24, № 2, p. 259-268, 1989.

COCKERHAM, C. C. Estimation of genetic variances. In: Statistical genetics and plant breeding W. D. Hanson \& H. F. Robinson (ed.). Pub. 982. National 
Acacdemy of Sciences-National Researches Council, Washington, D.C., 1963, p. 53-94.

CRUZ, C. D.; TORRES, R. A. de A.; VENCOVSKY, R. An alternative approach to the stability analysis proposed by Silva and Barreto. Revista Brasileira de Genética, v. 12, n³, p. 567-580, 1989.

EBERHART, S. A.; RUSSELL, W. A.; PENNY, L. H. Double crosses hybrid prediction in maize when epistasis is present. Crop Science, v. 4, p.363-366, 1964.

EBERHART;; S. A.; RUSSELL, W. A. Stability parameters for comparing varieties. Crop Science, v. 6, p.36-40, 1966.

ELGERSMA, A. Spaced-plant traits related to seed yield in plots of perennial ryegrass (Lolium perenne L.). Euphytica, v. 51, p. 151-161, 1990.

ERICKSON, L. R.; BEVERSDORF, W. D.; BALL, S. T. Genotype $x$ environment interactions for protein in Glycine max x Glycine soja crosses. Crop Science, v. 22, p. $1099-1101,1982$.

ESCRIBANO, M. R.; SANTALLA, M.; RON, A. M de. Genetic diversity in pod and seed quality traits of common bean populations from northwestern Spain. Euphytica, v. 93, p. 71-81, 1997.

FALCONER, D. S.; MACKAY, T. F. C. Introduction to quantitative genetics. Fourth Edition. Longman Edit. Malasya, 1996. 464 p. 
FEHR, W. R. Principles of cultivar development. v. 1. lowa state University. Macmillan Publihshing Company. New York, 1987. 487 p.

FOX, P. N.; ROSIELLE, A. A. Reducing the influence of environmental maineffects on pattern analysis of plant breeding environments. Euphytica, v. 31, p. 645-656, 1982.

GHADERI A.; EVERSON; E. H.; CRESS, C. E. Classification of environments and genotypes in wheat. Crop Science, v. 20, p.707-710, 1980.

GAUCH, H. G. Jr.; ZOBEL, R. W. Identifying Mega-Environments and Targeting Genotypes. Crop Science, v. 37, p.311-326, 1997.

HADJICHRISTODOULOU, A. Environmental correlations among grain yield and other important traits of wheat in drylands. Euphytica, v. 44, p. 143-150, 1989.

HERBERT, S. J.; LITCHFIELD, G. V. Partitioning soybean seed yield components. Crop Science, v. 22, p. 1074-1079, 1982.

JENSEN, N. F. Intra-varietal diversification in oat breeding. Agronomy Journal, v. 44, p. $30-34,1952$.

KONIECZNY, G.; MUSZYNSKY, A.; NAWRACALA, J. Variation and heritability of phenological characteristics of soybean genotypes in Polish conditions. Soybean Genetics Newsletter, v.19, p. 78-85, 1992.

LIN, C. S.; BINNS, M. R.; LEFKOVITCH, L.P. Stability analysis: where do we stand. Crop Science, v. 26, p. 894-900, 1986. 
MEBRAHTU, T.; ELMI, A. Stability analysis of vegetable soybean. Soybean Genetics Newsletter, v.24, p. 214-216, 1997.

MISEVIC, D.; J. DUMANOVIC, J. Examination of methods for choosing locations for preliminary maize yield testing. Euphytica, v. 44, p. 173-180, 1989.

NATIONAL RESEARCH COUNCIL. Genetic vulnerability of major crops. National Academy of Sciences Editor. Washington D.C., 1972, 307 p.

PANTER, D. M.; ALLEN, F. L. Simulated selection for superior yielding soybean lines in conventional versus double crop nursery environments. Crop Science, v. 29, p.1341-1347, 1989.

PIMENTEL, A. M. Cruzamentos dialélicos em soja com ênfase em teor de proteina e produção de grãos. Piracicaba, 1991. 150p. Dissertação (M.S.)Escola Superior de Agricultura "Luiz de Queiroz", Universidade de São Paulo.

PRADO, L. C. Perspectivas para o melhoramento de linhagens homozigóticas de soja, com ênfase em produção de grãos e teor de proteína. Piracicaba, 1994. 128p. Dissertação (M.S.)-Escola Superior de Agricultura "Luiz de Queiroz", Universidade de São Paulo.

RANZANI, G.; FREIRE, O. \& KINJO T. Carta de solos do municipio de Piracicaba. Piracicaba, ESALQ/Centro de Estudos de Solos, 1966. 86p. (mimeografado).

RASMUSSON D. C.; GLASS.; R. L. Estimates of genetic and environmental variability in barley. Crop Science, v. 7, p.185-188, 1967. 
RASMUSSON D. C.; LAMBERT; J. W. Variety $x$ environment interactions in barley.variety tests. Crop Science, v. 1, p.261-262, 1961.

ROMAGOSA I.; FOX, P. N. Genotype x environment interaction and adaptation. In: Plant Breeding: Principles and prospects. Chapman \& Hall Editors. London, 1994, Chapter 20, p. 373-390.

ROSIELLE A. A.; HAMBLIN, J. Theoretical aspects of selection for yield in stress and non-stress environments. Crop Science, v. 21, p.943-946, 1981.

SILVA, J. G. C.; BARRETO, J. N. Aplicação da regressão linear bisegmentada em estudos de interação genótipo $x$ ambiente. In: $1^{\circ}$ Simpósio de Estatística Aplicada à Experimentação Agronômica. Resumos. Campinas, Fundação Cargill, p. 49-50, 1985.

SINGH, S. P.; CAJIAO, C.; GUTIÉRREZ, J. A.; GARCIA, J.; PASTORCORRALES, M. A.; MORALES, F. J. Selection for seed yield in inter-gene pool crosses of common bean (Phaseolus vulgaris L.). Crop Science, v. 29, p.1126-1131, 1989.

SINGH, S. P.; GUTIÉRREZ, J. A. Effect of plant density on selection for seed yield in two populations of Phaseolus vulgaris L.. Euphytica, v. 51, p. 173$178,1990$.

SNELLER, C. H.; KILGORE-NORQUEST, L.; DOMBEK, D. Repeatability of yield stability statistics in soybean. Crop Science, v. 37, p.383-390, 1997. 
SPRAGUE, G. F.; FEDERER, W. T. A comparison of variance components in corn yield trials: II. Error, year $x$ variety, location $x$ variety, and variety components. Agronomy Journal, v. 43, p. 535-541, 1951.

VENCOVSKY, R.; BARRIGA, P. Genética biométrica no fitomelhoramento. Sociedade Brasileira de Genética. Ribeirão Preto SP. Brasil. 1992, 486 p.

VERMA, M. M.; CHAHAL, C. S.; MURTY, B. R. Limitations of conventional regression analysis: a proposed modification. Theoretical and Applied Genetics, v. 53, p. 89-91, 1978.

VIRK, D. S.; SINGH, N. B.; SRIVASTAVA, M.; HARINARAYANA, G. Regression analysis for general adaptation in pearl millet using different environmental indices. Theoretical and Applied Genetics, v. 68, p. 509-513, 1984.

VIRK, D. S.; MANGAT, B. K. Detection of cross over genotype $x$ environment interactions in pearl millet. Euphytica, v. 52, p. 193-199, 1991.

VOSE, P. B. Effects of genetic factors on nutritional requeriments of plants. In: Crop Breeding a contemporary basis. Vose \& Blixt Editors. Oxford, 1984, Chapter 4, p. 67-114.

XIANGXUN, M.; SHUMING, W.; AIPING, L; MINGXIANG, H. Protein and oil content of soybean seed as influenced by years and locations. Soybean Genetics Newsletter, v.18, p. 113-116, 1992.

YANG, R. C.; BAKER, R. J. Genotype-Environment interactions in two wheat crosses. Crop Science, v. 31, p. 83-87, 1991. 
TABELAS 
Tabela 2: Valores dos coeficientes de variação experimental (CVe), expressos em porcentagem, e das médias de progênies para o caráter produção de grãos ( $\mathrm{g} /$ parcela), relativas as três populações (Pop. 1, 2 e 3 ), envolvendo os três anos de avaliação (1993/94, 1994/95 e 1995/96), e considerando as anovas individuais.

\begin{tabular}{ccrrr}
\hline ANOS & PARÂMETRO & POP. 1 & POP. 2 & POP.3 \\
\hline \multirow{2}{*}{$93 / 94$} & CVe & 23,22 & 15,73 & 20,23 \\
& Média & 212,71 & 187,67 & 219,78 \\
& & & & \\
\multirow{2}{*}{$94 / 95$} & CVe & 20,03 & 18,60 & 17,51 \\
& Média & 177,79 & 171,96 & 191,15 \\
& CVe & 15,81 & 16,65 & 14,31 \\
& Média & 196,40 & 181,21 & 226,64 \\
& CVe & 19,69 & 16,99 & 17,35 \\
& Média & 195,63 & 180,28 & 212,51 \\
\hline
\end{tabular}


Tabela 3: Análise da variância individual (agrupando 3 conjuntos) para a população 1, e para o caráter produção de grãos, ano 1993/94.

\begin{tabular}{lcrll}
\hline \multicolumn{1}{c}{ F.V. } & GL & \multicolumn{1}{c}{ QM } & F & Pr. $>$ F \\
\hline CONJUNTOS (C) & 2 & 909,91 & 0,37 & $0,6898^{\text {ns }}$ \\
REPETIÇÃO (R)/C & 5 & 6431,77 & 2,64 & $0,0288^{*}$ \\
PROGÊNIES (P)/C & 57 & 8999,51 & 3,69 & $0,0001^{* *}$ \\
RESÍDUO/C & 87 & 2439,69 & & \\
\hline${ }^{\text {ns: não significativo, }}$ ": significativo ao 5\%, ${ }^{* *}$ : significativo ao 1\%
\end{tabular}

Tabela 4: Análise da variância individual (agrupando 3 conjuntos) para a população 1, e para o caráter produção de grãos, ano 1994/95.

\begin{tabular}{|c|c|c|c|c|}
\hline F.V. & $\overline{G L}$ & $\overline{Q M}$ & $\bar{F}$ & $\operatorname{Pr} .>F$ \\
\hline CONJUNTOS (C) & 2 & 17131,10 & 13,51 & $0,0001^{* *}$ \\
\hline REPETIÇÃO (R)/C & 6 & 1182,87 & 0,93 & $0,4746^{\text {ns }}$ \\
\hline PROGÊNIES (P)/C & 57 & 5275,50 & 4,16 & $0,0001^{\star *}$ \\
\hline RESÍDUO/C & 111 & 1268,16 & & \\
\hline
\end{tabular}

Tabela 5: Análise da variância individual (agrupando 3 conjuntos) para a população 1, e para o caráter produção de grãos, ano 1995/96.

\begin{tabular}{lcrrl}
\hline \multicolumn{1}{c}{ F.V. } & GL & \multicolumn{1}{c}{ QM } & \multicolumn{1}{c}{ F } & Pr. > F \\
\hline CONJUNTOS (C) & 2 & 23008,81 & 23,84 & $0,0001^{\star *}$ \\
REPETIÇÃO (R)/C & 6 & 1429,62 & 1,48 & $0,1911^{\text {ns }}$ \\
PROGÊNIES (P)/C & 57 & 7900,89 & 8,19 & $0,0001^{* *}$ \\
RESÍDUO/C & 111 & 965,24 & & \\
\hline
\end{tabular}

${ }^{\text {ns: }}$ : não significativo, *: significativo ao $5 \%$, ${ }^{\star \star}$ : significativo ao $1 \%$ 
Tabela 6: Análise da variância individual (agrupando 3 conjuntos) para a população 2, e para o caráter produção de grãos, ano 1993/94.

\begin{tabular}{lcrrc}
\hline \multicolumn{1}{c}{ F.V. } & GL & QM & \multicolumn{1}{c}{$F$} & Pr. > F \\
\hline CONJUNTOS (C) & 2 & 13475,82 & 15,47 & $0,0001^{* *}$ \\
REPETIÇÃO (R)/C & 5 & 1142,46 & 1,31 & $0,2662^{\text {ns }}$ \\
PROGÊNIES (P)/C & 57 & 2332,46 & 2,68 & $0,0001^{* *}$ \\
RESÍDUO/C & 90 & 871,02 & & \\
\hline
\end{tabular}

ns: não significativo, *: significativo ao $5 \%$, **: significativo ao $1 \%$

Tabela 7: Análise da variância individual (agrupando 3 conjuntos) para a população 2, e para o caráter produção de grãos, ano 1994/95.

\begin{tabular}{lcccc}
\hline \multicolumn{1}{c}{ F.V. } & GL & QM & F & Pr. $>$ F \\
\hline CONJUNTOS (C) & 2 & 490,36 & 0,48 & $0,6205^{\text {ns }}$ \\
REPETIÇÃO (R)/C & 6 & 1734,60 & 1,70 & $0,1287^{\text {ns }}$ \\
PROGÊNIES (P)/C & 57 & 2739,03 & 2,68 & $0,0001^{* *}$ \\
RESÍDUO/C & 111 & 1023,17 & & \\
\hline
\end{tabular}

${ }^{\text {ns }}$ : não significativo, *: significativo ao $5 \%$, **: significativo ao $1 \%$

Tabela 8: Análise da variância individual (agrupando 3 conjuntos) para a população 2, e para o caráter produção de grãos, ano 1995/96.

\begin{tabular}{lcccc}
\hline \multicolumn{1}{c}{ F.V. } & GL & QM & F & Pr. > F \\
\hline CONJUNTOS (C) & 2 & 6659,21 & 7,32 & $0,0010^{\star \star}$ \\
REPETIÇÃO (R)/C & 6 & 1142,64 & 1,26 & $0,2836^{\text {ns }}$ \\
PROGÊNIES (P)/C & 57 & 3448,91 & 3,79 & $0,0001^{\star *}$ \\
RESÍDUO/C & 114 & 910,03 & & \\
\hline
\end{tabular}

${ }^{\text {ns. }}$ não significativo, ${ }^{*}$ : significativo ao $5 \%$, ${ }^{\star \star}$ : significativo ao $1 \%$ 
Tabela 9: Análise da variância individual (agrupando 3 conjuntos) para a população 3, e para o caráter produção de grãos, ano 1993/94.

\begin{tabular}{lcccc}
\hline \multicolumn{1}{c}{ F.V. } & GL & QM & F & Pr. > F \\
\hline CONJUNTOS (C) & 2 & 15759,30 & 7,97 & $0,0006^{* *}$ \\
REPETIÇÃO (R)/C & 5 & 5284,36 & 2,67 & $0,0265^{*}$ \\
PROGÊNIES (P)/C & 57 & 8119,80 & 4,11 & $0,0001^{\star *}$ \\
RESÍDUO/C & 93 & 1977,21 & & \\
\hline
\end{tabular}



Tabela 10: Análise da variância individual (agrupando 3 conjuntos) para a população 3, e para o caráter peso de grãos, ano 1994/95.

\begin{tabular}{lcccc}
\hline \multicolumn{1}{c}{ F.V. } & GL & QM & F & Pr. > F \\
\hline CONJUNTOS (C) & 2 & 3554,63 & 3,17 & $0,0459^{*}$ \\
REPETIÇÃO (R)/C & 6 & 1978,84 & 1,77 & $0,1131^{\text {ns }}$ \\
PROGÊNIES (P)/C & 57 & 2936,01 & 2,62 & $0,0001^{* *}$ \\
RESÍDUO/C & 106 & 1120,65 & & \\
\hline${ }^{\text {ns: não significativo, *: significativo ao 5\%, **: significativo ao 1\% }}$
\end{tabular}

Tabela 11: Análise da variância individual (agrupando 3 conjuntos) para a população 3, e para o caráter produção de grãos, ano 1995/96.

\begin{tabular}{lcccc}
\hline \multicolumn{1}{c}{ F.V. } & GL & QM & F & Pr. > F \\
\hline CONJUNTOS (C) & 2 & 4331,49 & 4,12 & $0,0189^{*}$ \\
REPETIÇÃO (R) & 6 & 3584,72 & 3,41 & $0,0040^{* *}$ \\
PROGÊNIES (P)/C & 57 & 5823,82 & 5,54 & $0,0001^{* *}$ \\
RESÍDUO/C & 111 & 1051,99 & & \\
\hline
\end{tabular}

${ }^{\text {nss }}$; não significativo, ${ }^{*}$ : significativo ao $5 \%,{ }^{\star \star *}$ : significativo ao $1 \%$ 
Tabela 12: Análise da variância conjunta (agrupando 3 conjuntos) para a população 1, e para o caráter produção de grãos nos anos de 1993/94 e 1994/95.

\begin{tabular}{|c|c|c|c|c|}
\hline F.V. & $\overline{G L}$ & QM & $\bar{F}$ & Pr. $>F$ \\
\hline CONJUNTOS $(\mathrm{C})$ & 2 & 10756,79 & 2,04 & $0,1389^{\text {ns }}$ \\
\hline ANOS $(A) / C$ & 3 & 32831,27 & 6,24 & $0,0010^{* *}$ \\
\hline REPETIÇÃO(R)/AVC & 11 & 3568,73 & 0,68 & $0,7532^{\text {ns }}$ \\
\hline PROGÊNIES (P)/C & 57 & 9059,52 & 1,72 & $0,0212^{*}$ \\
\hline PROG. $\times$ ANO/C & 57 & 5263,34 & 2,95 & $0,0001^{* *}$ \\
\hline RESÍDUO/A/C & 198 & 1782,93 & & \\
\hline
\end{tabular}

Tabela 13: Análise da variância conjunta (agrupando 3 conjuntos) para a população 1, e para o caráter produção de grãos nos anos de 1993/94 e 1995/96.

\begin{tabular}{lcrcc}
\hline \multicolumn{1}{c}{ F.V. } & GL & \multicolumn{1}{c}{ QM } & F & Pr. $>$ F \\
\hline CONJUNTOS (C) & 2 & 8063,05 & 1,45 & $0,2421^{\text {ns }}$ \\
ANOS (A)/C & 3 & 15746,65 & 2,84 & $0,0458^{*}$ \\
REPETIÇÃO(R)/A/C & 11 & 3703,33 & 0,67 & $0,7622^{\text {ns }}$ \\
PROGÉNIES (P)/C & 57 & 11143,86 & 2,01 & $0,0047^{\star *}$ \\
PROG. X ANO/C & 57 & 5543,79 & 3,44 & $0,0001^{\text {** }}$ \\
RESÍDUO/AVC & 198 & 1613,10 & & \\
\hline
\end{tabular}

"ns: não significativo, *: significativo ao $5 \%$, **: significativo ao $1 \%$ 
Tabela 14: Análise da variância conjunta (agrupando 3 conjuntos) para a população 1, e para o caráter produção de grãos nos anos de 1994/95 e 1995/96.

\begin{tabular}{lcrrr}
\hline \multicolumn{1}{c}{ F.V. } & GL & QM & F & Pr. $>F$ \\
\hline CONJUNTOS (C) & 2 & 27537,54 & 12,49 & $0,0001^{\star *}$ \\
ANOS (A)/C & 3 & 18582,04 & 8,43 & $0,0010^{* *}$ \\
REPETIÇÃO(R)/A/C & 12 & 1306,25 & 0,59 & $0,8392^{\text {ns }}$ \\
PROGÊNIES (P)/C & 57 & 10921,85 & 4,95 & $0,0001^{* *}$ \\
PROG. X ANO/C & 57 & 2204,88 & 2,95 & $0,0001^{* *}$ \\
RESÍDUO/A/C & 222 & 1116,70 & & \\
\hline
\end{tabular}

ns: não significativo, *: significativo ao $5 \%$, ${ }^{\text {**: }}$ significativo ao $1 \%$

Tabela 15: Análise da variância conjunta (agrupando 3 conjuntos) para a população 1, e para o caráter produção de grãos nos anos de 1993/94 1994/95 e 1995/96.

\begin{tabular}{lcrcc}
\hline \multicolumn{1}{c}{ F.V. } & GL & QM & F & Pr. $>$ F \\
\hline CONJUNTOS (C) & 2 & 16973,48 & 3,92 & $0,0226^{*}$ \\
ANOS (A)/C & 6 & 22708,57 & 5,24 & $0,0001^{\star *}$ \\
REPETIÇÃO(R)/A/C & 17 & 2813,75 & 0,65 & $0,8449^{\text {ns }}$ \\
PROGENIES (P)/C & 57 & 13324,32 & 3,08 & $0,0001^{* *}$ \\
PROG. X ANO/C & 114 & 4331,31 & 2,95 & $0,0001^{* *}$ \\
RESÍDUO/AVC & 309 & 1489,19 & & \\
\hline
\end{tabular}

"ns, não significativo, *: significativo ao $5 \%$, **: significativo ao $1 \%$ 
Tabela 16: Análise da variância conjunta (agrupando 3 conjuntos) para a população 2, e para o caráter produção de grãos nos anos de $1993 / 94$ e $1994 / 95$.

\begin{tabular}{lcccc}
\hline \multicolumn{1}{c}{ F.V. } & GL & \multicolumn{1}{c}{ QM } & F & Pr. > F \\
\hline CONJUNTOS (C) & 2 & 9245,03 & 5,53 & $0,0064^{* *}$ \\
ANOS (A)/C & 3 & 10022,85 & 6,00 & $0,0013^{* *}$ \\
REPETIÇÃO(R)/A/C & 11 & 1465,44 & 0,88 & $0,5674^{\text {ns }}$ \\
PROGÊNIES (P)/C & 57 & 3471,69 & 2,08 & $0,0033^{* *}$ \\
PROG. x ANO/C & 57 & 1671,36 & 2,95 & $0,0001^{* *}$ \\
RESÍDUO/A/C & 201 & 955,04 & & \\
\hline
\end{tabular}

${ }^{\text {ns: }}$ : não significativo, ${ }^{*}$ : significativo ao $5 \%$, ${ }^{\text {**: }}$ : significativo ao $1 \%$

Tabela 17: Análise da variância conjunta (agrupando 3 conjuntos) para a população 2, e para o caráter produção de grãos nos anos de 1993/94 e $1995 / 96$.

\begin{tabular}{lcccc}
\hline \multicolumn{1}{c}{ F.V. } & GL & QM & F & Pr. $>$ F \\
\hline CONJUNTOS (C) & 2 & 15569,83 & 5,88 & $0,0048^{\star \star}$ \\
ANOS (A)/C & 3 & 3993,77 & 1,51 & $0,2219^{\text {ns }}$ \\
REPETIICÃO(R)/A/C & 11 & 1142,56 & 0,43 & $0,9353^{\text {ns }}$ \\
PROGÊNIES (P)/C & 57 & 3104,40 & 1,17 & $0,2743^{\text {ns }}$ \\
PROG. x ANO/C & 57 & 2646,19 & 2,96 & $0,0001^{\star \star}$ \\
RESÍDUO/AVC & 204 & 892,82 & & \\
\hline
\end{tabular}

${ }^{\text {ns }}$ : não significativo, ${ }^{\text {; }}$ : significativo ao $5 \%,{ }^{\star \star}$ : significativo ao $1 \%$ 
Tabela 18: Análise da variância conjunta (agrupando 3 conjuntos) para a população 2, e para o caráter produção de grãos nos anos de 1994/95 e $1995 / 96$.

\begin{tabular}{lcccc}
\hline \multicolumn{1}{c}{ F.V. } & GL & QM & $F$ & Pr. $>F$ \\
\hline CONJUNTOS (C) & 2 & 5260,22 & 3,36 & $0,0419^{*}$ \\
ANOS (A)/C & 3 & 3899,47 & 2,49 & $0,0696^{\text {ns }}$ \\
REPETIÇÃO(R)/A/C & 12 & 1438,62 & 0,92 & $0,5356^{\text {ns }}$ \\
PROGÊNIES (P)/C & 57 & 4626,33 & 1,62 & $0,0001^{* *}$ \\
PROG. x ANO/C & 57 & 1567,67 & 2,95 & $0,0001^{* *}$ \\
RESÍDUO/A/C & 225 & 965,85 & & \\
\hline
\end{tabular}

Tabela 19: Análise da variância conjunta (agrupando 3 conjuntos) para a população 2, e para o caráter produção de grãos nos anos de 1993/94 $1994 / 95$ e 1995/96.

\begin{tabular}{lcccc}
\hline \multicolumn{1}{c}{ F.V. } & GL & QM & F & Pr. $>F$ \\
\hline CONJUNTOS (C) & 2 & 13152,13 & 6,76 & $0,0017^{* \star}$ \\
ANOS (A)/C & 6 & 5949,05 & 3,06 & $0,0083^{\star \star}$ \\
REPETIÇÃO(R)/A/C & 17 & 1351,51 & 0,69 & $0,8030^{\text {ns }}$ \\
PROGÊNIES (P)/C & 57 & 4592,13 & 2,36 & $0,0001^{* \star}$ \\
PROG. x ANO/C & 114 & 1946,86 & 2,07 & $0,0001^{* *}$ \\
RESÍDUO/A/C & 315 & 938,75 & & \\
\hline
\end{tabular}

${ }^{\text {ns }}$ : não significativo, ${ }^{*}$ : significativo ao $5 \%$, ${ }^{* *}$ : significativo ao $1 \%$ 
Tabela 20: Análise da variância conjunta (agrupando 3 conjuntos) para a população 3, e para o caráter produção de grãos nos anos de 1993/94 e $1994 / 95$.

\begin{tabular}{lcccc}
\hline \multicolumn{1}{c}{ F.V. } & GL & QM & F & Pr. $>$ F \\
\hline CONJUNTOS (C) & 2 & 16740,43 & 4,04 & $0,0230^{*}$ \\
ANOS (A)/C & 3 & 25074,33 & 6,04 & $0,0012^{\star *}$ \\
REPETIÇÃO(R)/A/C & 11 & 3481,35 & 0,84 & $0,6025^{\text {ns }}$ \\
PROGÊNIES (P)/C & 57 & 7026,59 & 1,69 & $0,0245^{*}$ \\
PROG. x ANO/C & 57 & 4184,56 & 2,73 & $0,0001^{\star *}$ \\
RESÍDUO/AVC & 199 & 1520,95 & & \\
\hline
\end{tabular}

Tabela 21: Análise da variância conjunta (agrupando 3 conjuntos) para a população 3, e para o caráter produção de grãos nos anos de 1993/94 e $1995 / 96$.

\begin{tabular}{lcccc}
\hline \multicolumn{1}{c}{ F.V. } & GL & QM & $F$ & Pr. $>$ F \\
\hline CONJUNTOS (C) & 2 & 18183,48 & 3,78 & $0,0288^{*}$ \\
ANOS (A)/C & 3 & 2532,18 & 0,53 & $0,6661^{\text {ns }}$ \\
REPETIÇÃO(R)/A/C & 11 & 4357,28 & 0,91 & $0,5411^{\text {ns }}$ \\
PROGÊNIES (P)/C & 57 & 8951,89 & 1,86 & $0,0103^{* *}$ \\
PROG. x ANO/C & 57 & 4812,45 & 3,26 & $0,0001^{* *}$ \\
RESÍDUO/A/C & 202 & 1477,96 & & \\
\hline
\end{tabular}

${ }^{\text {ns }}$ : não significativo, ${ }^{*}$ : significativo ao $5 \%,{ }^{\text {**: }}$ : significativo ao $1 \%$ 
Tabela 22: Análise da variância conjunta (agrupando 3 conjuntos) para a população 3, e para o caráter produção de grãos nos anos de 1994/95 e $1995 / 96$.

\begin{tabular}{lcrrr}
\hline \multicolumn{1}{c}{ F.V. } & GL & \multicolumn{1}{c}{ QM } & \multicolumn{1}{c}{$F$} & Pr. $>F$ \\
\hline CONJUNTOS (C) & 2 & 7792,13 & 2,22 & $0,1180^{\text {ns }}$ \\
ANOS (A)/C & 3 & 38128,14 & 10,86 & $0,0001^{\text {** }}$ \\
REPETIÇÃO(R)/A/C & 12 & 2781,78 & 0,79 & $0,6562^{\text {ns }}$ \\
PROGÊNIES (P)/C & 57 & 5215,13 & 1,49 & $0,0691^{\text {ns }}$ \\
PROG. x ANO/C & 57 & 3510,82 & 3,23 & $0,0001^{\star *}$ \\
RESIDUO/A/C & 215 & 1085,84 & & \\
\hline
\end{tabular}

Tabela 23: Análise da variância conjunta (agrupando 3 conjuntos) para a população 3, e para o caráter produção de grãos nos anos de 1993/94 1994/95 e 1995/96.

\begin{tabular}{lcccc}
\hline \multicolumn{1}{c}{ F.V. } & GL & QM & F & Pr. $>$ F \\
\hline CONJUNTOS (C) & 2 & 20573,98 & 4,93 & $0,0088^{\star \star}$ \\
ANOS (A)/C & 6 & 22085,50 & 5,29 & $0,0001^{\star \star}$ \\
REPETIÇÃO(R)/AVC & 17 & 3517,83 & 0,84 & $0,6412^{\text {ns }}$ \\
PROGÊNIES (P)/C & 57 & 8525,82 & 2,04 & $0,0006^{\star *}$ \\
PROG. x ANO/C & 114 & 4173,93 & 3,08 & $0,0001^{\star *}$ \\
RESÍDUO/A/C & 308 & 1354,99 & & \\
\hline
\end{tabular}

\footnotetext{
${ }^{\text {ns: }}$ não significativo, ${ }^{*}$; significativo ao $5 \%$, ${ }^{* *}$ : significativo ao $1 \%$
} 
Tabela 24: Variâncias genéticas entre progênies $\left(\sigma^{2} \mathrm{P}\right)$ para o caráter produção de grãos (g/parcela) ${ }^{2}$, determinadas para as três populações (Pop. 1, 2 e 3), envolvendo os três anos de avaliação (1993/94, 1994/95 e 1995/96).

\begin{tabular}{cccc}
\hline ANOS & POP. 1 & POP 2 & POP. 3 \\
\hline $93 / 94$ & 2381,86 & 461,79 & 2190,29 \\
$94 / 95$ & 1140,53 & 597,31 & 462,36 \\
$95 / 96$ & 2065,85 & 852,80 & 1436,41 \\
\hline
\end{tabular}

Tabela 25: Valores da variância genética da interação progênies $x$ anos $\left(\sigma^{2}\right.$ PXA $)$, relativos as três populações (Pop. 1,2 e 3 ), envolvendo os três anos de avaliação (1993/94, 1994/95 e 1995/96), e considerando as anovas conjuntas.

\begin{tabular}{ccccc}
\hline ANOS & $\sigma^{2}$ PxA & POP. 1 & POP. 2 & POP.3 \\
\hline $93 / 94-94 / 95$ & $\sigma^{2}$ PxA(12) & $1160,14^{*}$ & 238,78 & 875,88 \\
$93 / 94-95 / 96$ & $\sigma^{2}$ PxA(13) & 1310,24 & 584,46 & 1111,5 \\
$94 / 95-95 / 96$ & $\sigma^{2}$ PxA(23) & 362,73 & 200,61 & 808,33 \\
\hline $\begin{array}{c}93 / 94-94 / 95 \text { e } \\
95 / 96\end{array}$ & $\sigma^{2}$ PxA(123) & 944,37 & 341,28 & 931,90 \\
\hline
\end{tabular}

${ }^{*}:$ valores expresados em gramas por parcela ${ }^{2}$. 
Tabela 26: Covariâncias genéticas entre progênies (média de 3 conjuntos) para - caráter produção de grãos, determinadas para as três populações (Pop. 1, 2 e 3), envolvendo os três anos de avaliação (1993/94, 1994/95 e 1995/96).

\begin{tabular}{cccc}
\hline ANOS & POP. 1 & POP 2 & POP. 3 \\
\hline $93 / 94-94 / 95$ & 791,75 & 293,75 & 502,20 \\
$93 / 94-95 / 96$ & 1039,23 & 63,016 & 673,85 \\
$94 / 95-95 / 96$ & 1371,41 & 487,05 & 263,20 \\
\hline
\end{tabular}

Tabela 27: Correlações genéticas de progênies (média de 3 conjuntos) para o caráter produção de grãos, determinadas para as três populações (Pop. 1, 2 e 3), envolvendo os três anos de avaliação (1993/94, 1994/95 e 1995/96).

\begin{tabular}{cccc}
\hline ANOS & POP. 1 & POP 2 & POP. 3 \\
\hline $93 / 94-94 / 95$ & 0,4633 & 0,5565 & 0,4512 \\
$93 / 94-95 / 96$ & 0,4622 & 0,098 & 0,3734 \\
$94 / 95-95 / 96$ & 0,7804 & 0,70 & 0,2683 \\
\hline
\end{tabular}


Tabela 28: Correlações fenotípicas entre médias de progênies (média de 3 conjuntos) para o caráter produção de grãos, determinadas para as três populações (Pop. 1, 2 e 3), envolvendo os três anos de avaliação (1993/94, 1994/95 e 1995/96).

\begin{tabular}{cccc}
\hline ANOS & POP. 1 & POP 2 & POP. 3 \\
\hline $93 / 94-94 / 95$ & 0,1996 & 0,3189 & 0,2811 \\
$93 / 94-95 / 96$ & 0,3374 & 0,0468 & 0,2501 \\
$94 / 95-95 / 96$ & 0,6317 & 0,4421 & 0,4131 \\
\hline
\end{tabular}


Tabela 29: Componentes da interação genéticos progênies $x$ anos para 0 caráter produção de grãos, determinados para as três populações (Pop. 1, 2 e $3)$, envolvendo os três anos de avaliação (1993/94, 1994/95 e 1995/96).

\begin{tabular}{|c|c|c|c|c|}
\hline ANOS & COMP. & POP. 1 & POP. 2 & POP.3 \\
\hline \multirow{5}{*}{$93 / 94-94 / 95$} & a & 112,99 & 4,35 & 319,99 \\
\hline & $\%$ & 11,66 & 1,85 & 38,83 \\
\hline & $b$ & 856,46 & 231,44 & 504,13 \\
\hline & $\%$ & 88,34 & 98,15 & 61,17 \\
\hline & $a+b^{1}$ & 969,45 & 235,80 & 824,13 \\
\hline \multirow{5}{*}{$93 / 94-95 / 96$} & $\bar{a}$ & 7,48 & 26,49 & 40,70 \\
\hline & $\%$ & 0,62 & 4,39 & 3,55 \\
\hline & $b$ & 1202,39 & 577,21 & 1104,51 \\
\hline & $\%$ & 99,38 & 95,61 & 96,45 \\
\hline & $a+b$ & 1209,87 & 603,70 & 1145,22 \\
\hline \multirow{5}{*}{$94 / 95-95 / 96$} & a & 53,23 & 9,94 & 111,12 \\
\hline & $\%$ & 11,77 & 4,48 & 13,31 \\
\hline & $b$ & 399,04 & 212,13 & 723,54 \\
\hline & $\%$ & 88,23 & 95,52 & 86,69 \\
\hline & $a+b$ & 452,27 & 222,07 & 834,67 \\
\hline \multirow{5}{*}{$93 / 94-94 / 95$ e $95 / 96$} & $a$ & 57,90 & 13,60 & 157,27 \\
\hline & $\%$ & 6,60 & 3,84 & 16,83 \\
\hline & $b$ & 819,29 & 340,26 & 777,39 \\
\hline & $\%$ & 93,40 & 96,16 & 83,17 \\
\hline & $a+b$ & 877,19 & 353,86 & 934,67 \\
\hline
\end{tabular}

${ }^{1}: a+b: \sigma_{\mathrm{PXA}}^{2}$ Variância da interação progênie $\mathrm{x}$ ano. 
Tabela 30: Componentes da interação fenotípicos progênies $x$ anos para 0 caráter produção de grãos, determinados para as três populações (Pop. 1, 2 e 3), envolvendo os três anos de avaliação (1993/94, 1994/95 e 1995/96).

\begin{tabular}{|c|c|c|c|c|}
\hline ANOS & COMP. & POP. 1 & POP. 2 & POP.3 \\
\hline \multirow{5}{*}{$93 / 94-94 / 95$} & $a$ & 247,16 & 8,16 & 645,30 \\
\hline & $\%$ & 4,29 & 0,47 & 15,53 \\
\hline & $\mathrm{b}$ & 5515,31 & 1721,54 & 3510,10 \\
\hline & $\%$ & 95,71 & 99,53 & 84,47 \\
\hline & $a+b^{1}$ & 5762,47 & 1729,67 & 4155,41 \\
\hline \multirow{5}{*}{$93 / 94-95 / 96$} & $a$ & 17,87 & 54,41 & 95,16 \\
\hline & $\%$ & 0,32 & 1,97 & 1,89 \\
\hline & $b$ & 5540,88 & 2703,54 & 4929,18 \\
\hline & $\%$ & 99,68 & 98,03 & 98,11 \\
\hline & $a+b$ & 5558,75 & 2757,95 & 5024,34 \\
\hline \multirow{5}{*}{$94 / 95-95 / 96$} & $a$ & 132,10 & 20,43 & 244,85 \\
\hline & $\%$ & 5,26 & 1,18 & 6,82 \\
\hline & $b$ & 2377,78 & 1714,73 & 3343,20 \\
\hline & $\%$ & 94,74 & 98,82 & 93,18 \\
\hline & $a+b$ & 2509,88 & 1735,16 & 3588,05 \\
\hline \multirow{5}{*}{$93 / 94-94 / 95$ e 95/96 } & $a$ & 132,38 & 27,67 & 328,44 \\
\hline & $\%$ & 2,86 & 1,33 & 7,72 \\
\hline & $b$ & 4493,45 & 2046,60 & 3927,50 \\
\hline & $\%$ & 97,14 & 98,67 & 92,28 \\
\hline & $a+b$ & 4625,83 & 2074,27 & 4255,94 \\
\hline
\end{tabular}

: $a+b:$ QMPXA: Quadrado médio da interação progênie $x$ ano. 
Tabela 31: Médias das 60 progênies da população 1 (caráter produção de grãos: g/parcela) ordenadas de maneira decrescente, considerando os três anos de avaliação (1993/94, 1994/95 e 1995/96).

POPULAÇÃO 1

\begin{tabular}{|c|c|c|c|c|c|c|}
\hline \multirow{2}{*}{$\begin{array}{l}\text { ORDEM } \\
>a<\end{array}$} & \multicolumn{2}{|c|}{ ANO $93 / 94$} & \multicolumn{2}{|c|}{ ANO 94/95 } & \multicolumn{2}{|c|}{ ANO 95/96 } \\
\hline & PROGÊNIE & MÉDIA & PROGÊNIE & MÉDIA & PROGENNIE & MÉDIA \\
\hline 1 & 16 & 372,60 & 4 & 344,03 & 17 & 383,81 \\
\hline 2 & 20 & 335,60 & 17 & 341,94 & 4 & 353,24 \\
\hline 3 & 4 & 330,40 & 11 & 300,73 & 11 & 289,67 \\
\hline 4 & 32 & 329,00 & 38 & 249,22 & 31 & 288,21 \\
\hline 5 & 55 & 314,50 & 6 & 244,34 & 34 & 269,09 \\
\hline 6 & 12 & 312,20 & 20 & 235,92 & 54 & 267,46 \\
\hline 7 & 31 & 299,67 & 31 & 232,56 & 12 & 263,65 \\
\hline 8 & 11 & 294,60 & 23 & 212,53 & 2 & 263,49 \\
\hline 9 & 38 & 291,85 & 26 & 202,79 & 50 & 260,26 \\
\hline 10 & 30 & 290,67 & 32 & 193,40 & 57 & 256,66 \\
\hline 11 & 35 & 289,33 & 50 & 193,06 & 44 & 253,79 \\
\hline 12 & 52 & 247,50 & 42 & 192,66 & 20 & 253,07 \\
\hline 13 & 47 & 243,50 & 44 & 187,79 & 32 & 241,47 \\
\hline 14 & 22 & 243,00 & 51 & 186,88 & 45 & 235,28 \\
\hline 15 & 2 & 242,80 & 34 & 182,99 & 46 & 217,77 \\
\hline 16 & 58 & 239,00 & 14 & 180,41 & 56 & 217,54 \\
\hline 17 & 37 & 233,33 & 12 & 179,50 & 55 & 217,42 \\
\hline 18 & 26 & 232,33 & 45 & 179,31 & 5 & 217,39 \\
\hline 19 & 60 & 230,50 & 57 & 178,38 & 52 & 216,57 \\
\hline 20 & 59 & 224,00 & 2 & 176,50 & 16 & 209,48 \\
\hline 21 & 10 & 220,00 & 13 & 176,50 & 51 & 205,46 \\
\hline 22 & 41 & 219,50 & 30 & 173,65 & 53 & 205,09 \\
\hline 23 & 42 & 214,50 & 5 & 172,81 & 25 & 200,20 \\
\hline 24 & 40 & 208,00 & 25 & 172,10 & 41 & 184,88 \\
\hline 25 & 57 & 207,00 & 24 & 170,69 & 43 & 184,79 \\
\hline 26 & 45 & 206,50 & 29 & 170,29 & 18 & 180,79 \\
\hline 27 & 17 & 203,80 & 18 & 169,22 & 59 & 176,36 \\
\hline 28 & 29 & 196,00 & 36 & 168,61 & 6 & 176,26 \\
\hline 29 & 54 & 192,00 & 47 & 165,47 & 10 & 175,95 \\
\hline 30 & 39 & 190,67 & 15 & 162,26 & 3 & 175,78 \\
\hline
\end{tabular}


Tabela 31: Médias das 60 progênies da população 1 (caráter produção de grãos: g/parcela) ordenadas de maneira decrescente, considerando os três anos de avaliação (1993/94, 1994/95 e 1995/96).

\begin{tabular}{rrrrrrr}
31 & 9 & 190,40 & 10 & 162,21 & 49 & 175,34 \\
32 & 25 & 188,04 & 8 & 161,69 & 60 & 174,16 \\
33 & 23 & 186,67 & 43 & 161,08 & 14 & 173,73 \\
34 & 56 & 185,50 & 58 & 160,91 & 24 & 173,52 \\
35 & 7 & 185,40 & 60 & 160,72 & 9 & 173,05 \\
36 & 15 & 184,80 & 16 & 158,56 & 40 & 169,91 \\
37 & 33 & 183,33 & 21 & 158,17 & 36 & 167,59 \\
38 & 53 & 182,00 & 7 & 157,68 & 8 & 166,35 \\
39 & 46 & 182,00 & 37 & 156,14 & 7 & 166,26 \\
40 & 48 & 181,50 & 52 & 154,94 & 13 & 166,19 \\
41 & 24 & 178,00 & 27 & 154,74 & 48 & 164,95 \\
42 & 44 & 177,50 & 46 & 154,09 & 22 & 160,49 \\
43 & 51 & 177,00 & 35 & 153,63 & 58 & 160,30 \\
44 & 5 & 174,87 & 3 & 153,50 & 35 & 158,88 \\
45 & 50 & 172,50 & 48 & 153,23 & 29 & 157,94 \\
46 & 3 & 170,80 & 41 & 153,22 & 37 & 157,57 \\
47 & 21 & 166,33 & 39 & 152,67 & 28 & 156,50 \\
48 & 43 & 163,50 & 1 & 151,73 & 1 & 154,93 \\
49 & 18 & 162,20 & 33 & 151,62 & 47 & 153,69 \\
50 & 1 & 160,64 & 59 & 150,21 & 30 & 152,98 \\
51 & 14 & 160,40 & 54 & 149,93 & 39 & 152,86 \\
52 & 13 & 157,97 & 53 & 146,92 & 33 & 152,63 \\
53 & 49 & 155,00 & 22 & 145,87 & 23 & 149,74 \\
54 & 8 & 154,50 & 9 & 142,76 & 26 & 147,40 \\
55 & 36 & 151,67 & 56 & 142,36 & 19 & 145,18 \\
56 & 6 & 149,78 & 19 & 140,77 & 42 & 144,90 \\
57 & 27 & 148,12 & 40 & 139,55 & 15 & 142,43 \\
58 & 19 & 147,61 & 49 & 138,50 & 38 & 141,22 \\
59 & 28 & 144,33 & 28 & 133,62 & 21 & 140,96 \\
60 & 34 & 141,33 & 55 & 130,74 & 27 & 140,07 \\
\hline
\end{tabular}


Tabela 32: Médias das 60 progênies da população 2 (caráter produção de grãos: g/parcela) ordenadas de maneira decrescente, considerando os três anos de avaliação (1993/94, 1994/95 e 1995/96).

\section{POPULAÇÃO 2}

\begin{tabular}{|c|c|c|c|c|c|c|}
\hline \multirow{2}{*}{$\begin{array}{l}\text { ORDEM } \\
>a<\end{array}$} & \multicolumn{2}{|c|}{ ANO 93/94 } & \multicolumn{2}{|c|}{ ANO 94/95 } & \multicolumn{2}{|c|}{ ANO 95/96 } \\
\hline & PROGENIE & MÉDIA & PROGENIE & MÉDIA & PROGÉNIE & MÉDIA \\
\hline 1 & 49 & 253,50 & 21 & 340.94 & 21 & 290,86 \\
\hline 2 & 33 & 248,00 & 9 & 235.25 & 5 & 285,01 \\
\hline 3 & 21 & 247,33 & 60 & 217.57 & 20 & 254,18 \\
\hline 4 & 39 & 246,33 & 11 & 208.13 & 12 & 250,10 \\
\hline 5 & 38 & 241,33 & 12 & 200.05 & 39 & 248,39 \\
\hline 6 & 29 & 241,00 & 26 & 193.95 & 24 & 233,57 \\
\hline 7 & 26 & 234,67 & 29 & 192.68 & 60 & 230,12 \\
\hline 8 & 40 & 232,00 & 39 & 191.72 & 14 & 228,62 \\
\hline 9 & 34 & 229,00 & 1 & 191.42 & 41 & 224,38 \\
\hline 10 & 32 & 228,67 & 42 & 190.82 & 1 & 223,39 \\
\hline 11 & 28 & 227,00 & 31 & 190.63 & 30 & 219,24 \\
\hline 12 & 17 & 221,00 & 28 & 189.66 & 27 & 211,64 \\
\hline 13 & 51 & 219,00 & 46 & 186.6 & 40 & 206,80 \\
\hline 14 & 15 & 218,33 & 5 & 185.96 & 48 & 200,30 \\
\hline 15 & 14 & 212,00 & 14 & 185.95 & 13 & 190.67 \\
\hline 16 & 11 & 211,00 & 47 & 184.29 & 35 & 184,56 \\
\hline 17 & 6 & 207,56 & 17 & 179.54 & 17 & 184,34 \\
\hline 18 & 60 & 201,00 & 27 & 179.24 & 9 & 179,03 \\
\hline 19 & 9 & 200,67 & 24 & 175.76 & 33 & 178,29 \\
\hline 20 & 52 & 198,50 & 13 & 175.11 & 19 & 177,35 \\
\hline 21 & 45 & 196,50 & 32 & 173.03 & 59 & 175,18 \\
\hline 22 & 36 & 191,33 & 8 & 172.93 & 11 & 174,84 \\
\hline 23 & 25 & 188,33 & 51 & 172.06 & 7 & 174,01 \\
\hline 24 & 2 & 185,67 & 55 & 171.89 & 42 & 173,02 \\
\hline 25 & 12 & 184,06 & 43 & 170.27 & 10 & 172,81 \\
\hline 26 & 4 & 180,00 & 18 & 170.01 & 29 & 171,67 \\
\hline 27 & 8 & 179,33 & 49 & 168.4 & 16 & 170,36 \\
\hline 28 & 48 & 179,00 & 4 & 167.73 & 6 & 168,78 \\
\hline 29 & 10 & 178,33 & 44 & 167.62 & 36 & 168,38 \\
\hline 30 & 35 & 178,33 & 19 & 167.61 & 45 & 168,22 \\
\hline
\end{tabular}


Tabela 32: Médias das 60 progênies da população 2 (caráter produção de grãos: g/parcela) ordenadas de maneira decrescente, considerando os três anos de avaliação (1993/94, 1994/95 e 1995/96).

\begin{tabular}{|c|c|c|c|c|c|c|}
\hline 31 & 13 & 172,33 & 10 & 167,12 & 52 & 167,92 \\
\hline 32 & 27 & 172,28 & 58 & 165,80 & 53 & 167,89 \\
\hline 33 & 7 & 172,00 & 57 & 165,17 & 47 & 167,39 \\
\hline 34 & 30 & 171,67 & 50 & 162,72 & 32 & 167,35 \\
\hline 35 & 1 & 169,67 & 48 & 162,64 & 46 & 166,93 \\
\hline 36 & 58 & 169,50 & 59 & 162,26 & 28 & 164,16 \\
\hline 37 & 19 & 169,00 & 41 & 161,96 & 2 & 164,01 \\
\hline 38 & 5 & 169,00 & 2 & 160,60 & 54 & 163,41 \\
\hline 39 & 46 & 167,68 & 34 & 159,22 & 18 & 162,79 \\
\hline 40 & 31 & 166,67 & 3 & 157,38 & 31 & 162,66 \\
\hline 41 & 50 & 166,50 & 6 & 155,99 & 55 & 162,19 \\
\hline 42 & 55 & 166,50 & 35 & 155,98 & 3 & 161,91 \\
\hline 43 & 23 & 165,00 & 56 & 155,31 & 26 & 161,65 \\
\hline 44 & 59 & 163,50 & 45 & 155,08 & 15 & 161,58 \\
\hline 45 & 53 & 163,00 & 15 & 153,46 & 34 & 161,52 \\
\hline 46 & 56 & 163,00 & 52 & 153,24 & 22 & 159,79 \\
\hline 47 & 37 & 162,67 & 38 & 153,19 & 38 & 159,60 \\
\hline 48 & 3 & 162,33 & 33 & 152,79 & 49 & 157,22 \\
\hline 49 & 42 & 162,00 & 30 & 151,96 & 50 & 156,88 \\
\hline 50 & 22 & 158,67 & 7 & 149,61 & 4 & 156,36 \\
\hline 51 & 18 & 152,67 & 40 & 149,09 & 51 & 155,50 \\
\hline 52 & 41 & 151,50 & 20 & 146,29 & 44 & 154,44 \\
\hline 53 & 20 & 151,00 & 53 & 145,88 & 57 & 154,05 \\
\hline 54 & 43 & 150,00 & 22 & 145,17 & 58 & 153,53 \\
\hline 55 & 16 & 148,33 & 37 & 144,85 & 56 & 151,60 \\
\hline 56 & 24 & 145,28 & 36 & 144,57 & 37 & 151,58 \\
\hline 57 & 47 & 140,00 & 25 & 144,23 & 23 & 149,97 \\
\hline 58 & 44 & 139,00 & 54 & 143,99 & 8 & 147,84 \\
\hline 59 & 57 & 137,50 & 16 & 142,29 & 25 & 146,83 \\
\hline 60 & 54 & 133,50 & 23 & 130,14 & 43 & 136,25 \\
\hline
\end{tabular}


Tabela 33: Médias das 60 progênies da população 3 (caráter produção de grãos: g/parcela) ordenadas de maneira decrescente, considerando os três anos de avaliação (1993/94, 1994/95 e 1995/96).

POPULAÇÃO 3

\begin{tabular}{|c|c|c|c|c|c|c|}
\hline \multirow{2}{*}{$\begin{array}{l}\text { ORDEM } \\
>a<\end{array}$} & \multicolumn{2}{|c|}{ ANO 93/94 } & \multicolumn{2}{|c|}{ ANO 94/95 } & \multicolumn{2}{|c|}{ ANO 95/96 } \\
\hline & PROGENNIE & MÉDIA & PROGENIE & MÉDIA & PROGÊNIE & MÉDIA \\
\hline 1 & 23 & 419,00 & 9 & 273,22 & 41 & 311,38 \\
\hline 2 & 41 & 365,00 & 42 & 261,81 & 14 & 307,35 \\
\hline 3 & 28 & 336,67 & 38 & 259,08 & 21 & 301,25 \\
\hline 4 & 21 & 309,00 & 23 & 257,65 & 43 & 299,09 \\
\hline 5 & 19 & 308,67 & 48 & 244,07 & 29 & 297,13 \\
\hline 6 & 53 & 308,00 & 35 & 236,18 & 55 & 289,03 \\
\hline 7 & 32 & 307,00 & 1 & 234,97 & 9 & 282,57 \\
\hline 8 & 7 & 286,67 & 50 & 232,99 & 36 & 281,87 \\
\hline 9 & 43 & 280,50 & 24 & 230,37 & 49 & 273,33 \\
\hline 10 & 38 & 274,33 & 55 & 219,16 & 57 & 272,53 \\
\hline 11 & 39 & 269,67 & 37 & 218,98 & 34 & 267,97 \\
\hline 12 & 59 & 267,50 & 12 & 215,75 & 32 & 267,73 \\
\hline 13 & 37 & 257,33 & 53 & 215,64 & 23 & 266,61 \\
\hline 14 & 13 & 249,33 & 41 & 215,63 & 56 & 265,43 \\
\hline 15 & 50 & 246,50 & 43 & 215,46 & 16 & 264,21 \\
\hline 16 & 1 & 240,33 & 7 & 211,24 & 52 & 263,71 \\
\hline 17 & 24 & 239,33 & 21 & 209,48 & 26 & 262,14 \\
\hline 18 & 56 & 235,50 & 28 & 208,23 & 37 & 259,87 \\
\hline 19 & 51 & 234,00 & 19 & 199,47 & 30 & 256,80 \\
\hline 20 & 45 & 233,50 & 26 & 198,63 & 53 & 256,31 \\
\hline 21 & 8 & 232,00 & 44 & 198,54 & 1 & 253,30 \\
\hline 22 & 42 & 231,00 & 30 & 197,13 & 28 & 252,03 \\
\hline 23 & 34 & 224,00 & 15 & 196,48 & 10 & 251,76 \\
\hline 24 & 44 & 220,50 & 14 & 194,81 & 40 & 247,27 \\
\hline 25 & 30 & 220,33 & 56 & 194,63 & 58 & 246,93 \\
\hline 26 & 10 & 215,67 & 40 & 194,35 & 39 & 241,75 \\
\hline 27 & 3 & 208,33 & 17 & 188,98 & 13 & 236,08 \\
\hline 28 & 11 & 205,67 & 33 & 188,65 & 18 & 231,61 \\
\hline 29 & 52 & 205,50 & 31 & 184,13 & 19 & 227,69 \\
\hline 30 & 49 & 203,50 & 2 & 183,61 & 25 & 225,14 \\
\hline
\end{tabular}


Tabela 33: Médias das 60 progênies da população 3 (caráter produção de grãos: g/parcela) ordenadas de maneira decrescente, considerando os três anos de avaliação (1993/94, 1994/95 e 1995/96).

\begin{tabular}{rrrrrrr}
31 & 33 & 201,00 & 29 & 183,56 & 48 & 223,97 \\
32 & 14 & 199,00 & 46 & 182,78 & 3 & 221,87 \\
33 & 58 & 198,50 & 60 & 181,87 & 8 & 221,72 \\
34 & 22 & 195,33 & 49 & 177,91 & 15 & 218,37 \\
35 & 60 & 195,00 & 39 & 175,20 & 50 & 217,93 \\
36 & 5 & 193,67 & 3 & 174,76 & 42 & 215,03 \\
37 & 27 & 192,67 & 34 & 173,63 & 47 & 212,34 \\
38 & 16 & 187,00 & 58 & 173,07 & 59 & 208,79 \\
39 & 20 & 186,33 & 59 & 171,49 & 5 & 206,90 \\
40 & 40 & 186,33 & 54 & 167,87 & 35 & 204,21 \\
41 & 15 & 185,00 & 36 & 167,12 & 12 & 203,00 \\
42 & 55 & 184,00 & 25 & 166,10 & 7 & 197,70 \\
43 & 57 & 182,50 & 22 & 165,13 & 60 & 194,59 \\
44 & 35 & 182,22 & 32 & 163,58 & 38 & 191,74 \\
45 & 47 & 180,00 & 8 & 161,58 & 27 & 188,19 \\
46 & 54 & 178,50 & 45 & 161,54 & 54 & 185,49 \\
47 & 36 & 177,76 & 27 & 161,23 & 44 & 175,63 \\
48 & 17 & 177,67 & 57 & 161,20 & 17 & 174,77 \\
49 & 48 & 177,50 & 18 & 161,04 & 22 & 173,35 \\
50 & 12 & 173,33 & 20 & 160,20 & 6 & 172,54 \\
51 & 29 & 172,67 & 6 & 158,87 & 4 & 172,33 \\
52 & 31 & 172,67 & 5 & 158,02 & 24 & 171,41 \\
53 & 25 & 171,67 & 13 & 157,30 & 51 & 170,94 \\
54 & 46 & 170,50 & 16 & 156,91 & 11 & 170,07 \\
55 & 4 & 167,67 & 51 & 156,21 & 20 & 169,57 \\
56 & 6 & 163,00 & 47 & 154,41 & 46 & 165,08 \\
57 & 26 & 162,00 & 4 & 149,53 & 33 & 161,47 \\
58 & 18 & 155,67 & 52 & 147,82 & 45 & 159,17 \\
59 & 9 & 153,33 & 11 & 147,53 & 31 & 158,80 \\
60 & 2 & 144,67 & 10 & 140,90 & 2 & 158,39 \\
\hline
\end{tabular}


Tabela 34: Ordenamento das médias das seis progênies superiores da população 1 (caráter produção de grãos: g/parcela), resultantes da simulação de uma intensidade de seleção do $10 \%$, e considerando sua performance média nos três anos de avaliação (1993/94, 1994/95 e 1995/96).

POPULAÇÃO 1

\begin{tabular}{cccccc}
\hline ORDEM & ANOS & ANO 93/94 & ANO 94/95 & ANO 95/96 & 3 ANOS \\
\hline$>$ a $<$ & PROGÉNIE & MÉDIA & MÉDIA & MÉDIA & MÉDIA \\
\hline 1 & 4 & 330,40 & 344,03 & 353,24 & 342,56 \\
2 & 17 & 203,80 & 341,94 & 383,81 & 309,85 \\
3 & 11 & 294,60 & 300,73 & 289,67 & 295,00 \\
4 & 20 & 335,60 & 235,92 & 253,07 & 274,86 \\
5 & 31 & 299,67 & 232,56 & 288,21 & 273,48 \\
6 & 32 & 329,00 & 193,40 & 241,47 & 254,62 \\
\hline
\end{tabular}

Tabela 35: Ordenamento das médias das seis progênies superiores da população 2 (caráter produção de grãos: g/parcela), resultantes da simulação de uma intensidade de seleção do $10 \%$, e considerando sua performance média nos três anos de avaliação (1993/94, 1994/95 e 1995/96).

POPULAÇÃO 2

\begin{tabular}{cccccc}
\hline ORDEM & ANOS & ANO 93/94 & ANO 94/95 & ANO 95/96 & 3 ANOS \\
\hline$>\mathrm{a}<$ & PROGÉNIE & MÉDIA & MÉDIA & MÉDIA & MÉDIA \\
\hline 1 & 21 & 247,33 & 340,94 & 290,86 & 293,04 \\
2 & 39 & 246,33 & 191,72 & 248,39 & 228,81 \\
3 & 60 & 201,00 & 217,57 & 230,12 & 216,23 \\
4 & 5 & 169,00 & 185,96 & 285,01 & 213,32 \\
5 & 12 & 184,06 & 200,05 & 250,10 & 211,40 \\
6 & 14 & 212,00 & 185,95 & 228,62 & 208,86 \\
\hline
\end{tabular}


Tabela 36: Ordenamento das médias das seis progênies superiores da população 3 (caráter produção de grãos: g/parcela), resultantes da simulação de uma intensidade de seleção do $10 \%$, e considerando sua performance média nos três anos de avaliação (1993/94, 1994/95 e 1995/96).

POPULAÇÃO 3

\begin{tabular}{cccccc}
\hline ORDEM & ANOS & ANO 93/94 & ANO 94/95 & ANO 95/96 & 3 ANOS \\
\hline$>$ a $<$ & PROGÊNIE & MÉDIA & MÉDIA & MÉDIA & MÉDIA \\
\hline 1 & 23 & 419,00 & 257,65 & 266,61 & 314,42 \\
2 & 41 & 365,00 & 215,63 & 311,38 & 297,34 \\
3 & 21 & 309,00 & 209,48 & 301,25 & 273,24 \\
4 & 28 & 336,67 & 208,23 & 252,03 & 265,64 \\
5 & 43 & 280,50 & 215,46 & 299,09 & 265,02 \\
6 & 53 & 308,00 & 215,64 & 256,31 & 259,98 \\
\hline
\end{tabular}


Tabela 37: Valores das médias das 20 progênies superiores, intermediárias e inferiores, e de sua oscilação expressa em porcentagem, para o caráter produção de grãos ( $\mathrm{g} /$ parcela), relativas a população 1 , envolvendo os três anos de avaliação (1993/94, 1994/95 e 1995/96).

\begin{tabular}{|c|c|c|c|c|c|c|}
\hline \multirow[b]{2}{*}{ ANOS } & \multicolumn{2}{|c|}{$\begin{array}{l}\text { PROGÉNIES } \\
\text { SUPERIORES } \\
\end{array}$} & \multicolumn{2}{|c|}{$\begin{array}{l}\text { PROGÊNIES } \\
\text { INTERMEDIÁRIAS }\end{array}$} & \multicolumn{2}{|c|}{$\begin{array}{l}\text { PROGENIIES } \\
\text { INFERIORES }\end{array}$} \\
\hline & MÉDIAS & $\begin{array}{c}\text { OSCILAÇÃO } \\
\%\end{array}$ & MÉDIAS & $\begin{array}{c}\text { OSCILAÇÃO } \\
\%\end{array}$ & MÉDIAS & $\begin{array}{c}\text { OSCILAÇĀO } \\
\%\end{array}$ \\
\hline $93 / 94$ & 279,82 & 21,47 & 193,28 & 15,36 & 160,70 & 8,53 \\
\hline $94 / 95$ & 219,75 & 7,52 & 163,60 & 8,65 & 146,98 & 5,55 \\
\hline $95 / 96$ & 258,77 & 17,76 & 176,56 & 7,92 & 151,78 & 3,27 \\
\hline $\begin{array}{c}93 / 94-94 / 95 \text { e } \\
95 / 96\end{array}$ & 252,78 & 15,58 & 177,81 & 10,64 & 153,15 & 5,78 \\
\hline
\end{tabular}

Tabela 38: Valores das médias das 20 progênies superiores, intermediárias e inferiores, e de sua oscilação expressa em porcentagem, para o caráter produção de grãos ( $\mathrm{g} /$ parcela), relativas a população 2 , envolvendo os três anos de avaliação (1993/94, 1994/95 e 1995/96).

\begin{tabular}{|c|c|c|c|c|c|c|}
\hline \multirow[b]{2}{*}{ ANOS } & \multicolumn{2}{|c|}{$\begin{array}{l}\text { PROGENIES } \\
\text { SUPERIORES } \\
\end{array}$} & \multicolumn{2}{|c|}{$\begin{array}{c}\text { PROGÊNIES } \\
\text { INTERMEDIÁRIAS }\end{array}$} & \multicolumn{2}{|c|}{$\begin{array}{l}\text { PROGENNIES } \\
\text { INFERIORES }\end{array}$} \\
\hline & MÉDIAS & $\begin{array}{c}\text { OSCILAÇÃO } \\
\%\end{array}$ & MÉDIAS & $\begin{array}{c}\text { OSCILAÇÃO } \\
\%\end{array}$ & MÉDIAS & $\begin{array}{c}\text { OSCILAÇÃO } \\
\%\end{array}$ \\
\hline $93 / 94$ & 225,89 & 11,57 & 175,53 & 5,71 & 154,10 & 3,53 \\
\hline $94 / 95$ & 199,76 & 2,59 & 165,5 & 4,32 & 148,66 & 0,59 \\
\hline $95 / 96$ & 220,04 & 10,15 & 167,94 & 1,47 & 155,01 & 4,27 \\
\hline $\begin{array}{c}93 / 94-94 / 95 \mathrm{e} \\
95 / 96\end{array}$ & 215,23 & 8,10 & 169,66 & 3,84 & 152,59 & 2,79 \\
\hline
\end{tabular}


Tabela 39: Valores das médias das 20 progênies superiores, intermediárias e inferiores, e de sua oscilação expressa em porcentagem, para o caráter produção de grãos ( $\mathrm{g} /$ parcela), relativas a população 3 , envolvendo os três anos de avaliação (1993/94, 1994/95 e 1995/96).

\begin{tabular}{ccccccc}
\hline & \multicolumn{2}{c}{$\begin{array}{c}\text { PROGENIES } \\
\text { SUPERIORES }\end{array}$} & $\begin{array}{c}\text { PROGENIES } \\
\text { INTERMEDIÁRIAS }\end{array}$ & \multicolumn{2}{c}{$\begin{array}{c}\text { PROGENIES } \\
\text { INFERIORES }\end{array}$} \\
\hline ANOS & MÉDIAS & $\begin{array}{c}\text { OSCILAÇÃO } \\
\%\end{array}$ & MÉDIAS & $\begin{array}{c}\text { OSCILAÇÃO } \\
\%\end{array}$ & $\begin{array}{c}\text { MÉDIAS } \\
\text { OSCILAÇÃo } \\
\%\end{array}$ \\
\hline $93 / 94$ & 283,39 & 19,58 & 202,72 & 9,92 & 171,62 & 8,05 \\
$94 / 95$ & 227,90 & 2,15 & 182,6 & 11,34 & 157,81 & 2,38 \\
$95 / 96$ & 277,32 & 21,68 & 225,72 & 23,61 & 175,71 & 11,34 \\
$93 / 94-94 / 95 e$ & 262,87 & 14,46 & 203,68 & 14,96 & 168,38 & 7,26 \\
$95 / 96$ & & & & & & \\
\hline
\end{tabular}


FIGURAS 


\section{PROD. GRÃOS}

(g/parcela)



Figura 2: Médias das 60 progênies para o caráter produção de grãos (g/parcela), relativas as três populações (Pop. 1, 2 e 3), envolvendo os três anos de avaliação (1993/94, 1994/95 e 1995/96). 


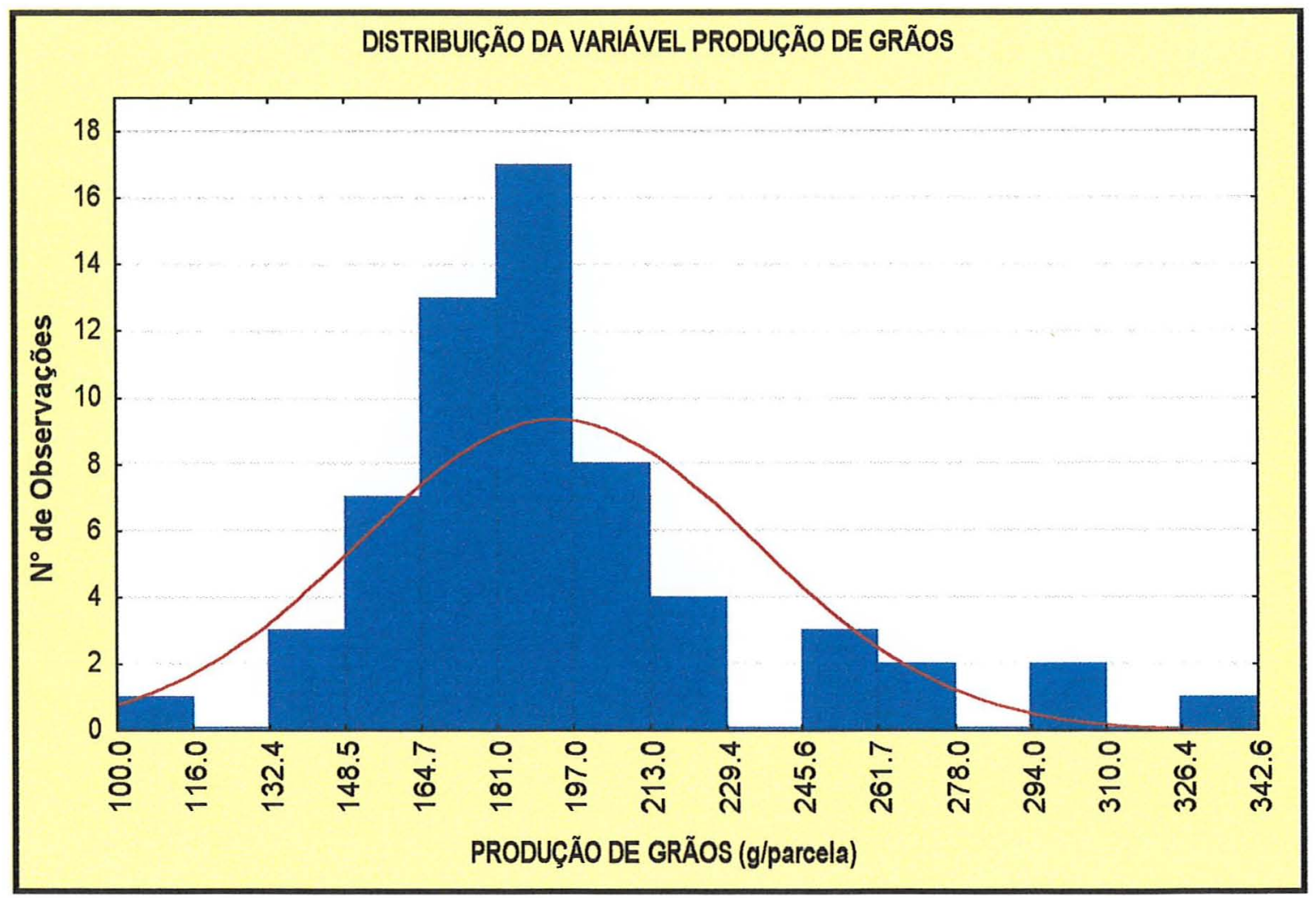

Figura 3: Histograma das médias das 60 progênies nos três anos de avaliação (1993/94, 1994/95 e 1995/96), para o caráter produção de grãos (g/parcela), relativo à população 1 . 


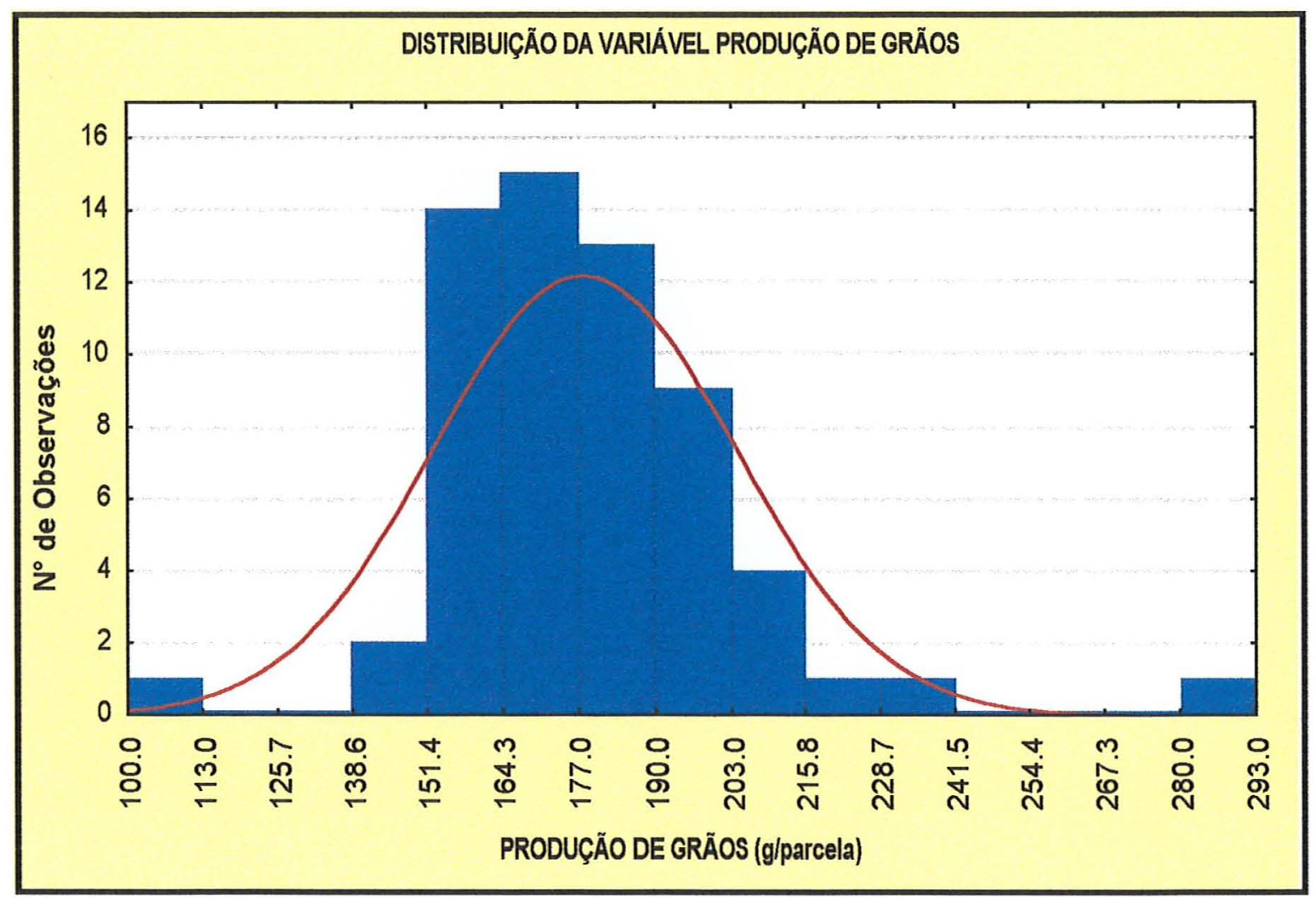

Figura 4: Histograma das médias das 60 progênies nos três anos de avaliação (1993/94, 1994/95 e 1995/96), para o caráter produção de grãos (g/parcela), relativo à população 2 . 




Figura 5: Histograma das médias das 60 progênies nos três anos de avaliação (1993/94, 1994/95 e 1995/96), para o caráter produção de grãos (g/parcela), relativo à população 3 . 


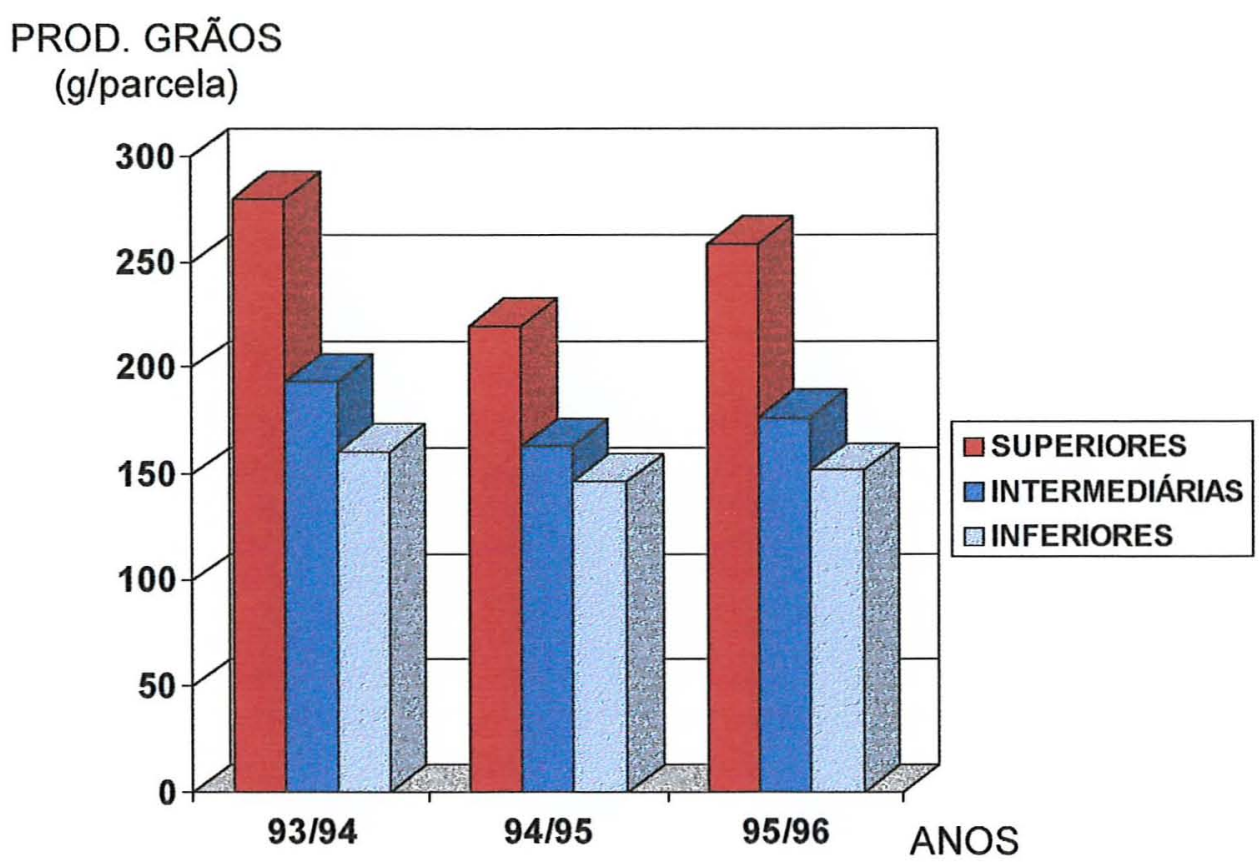

Figura 6: Médias das 20 progênies superiores, intermediárias, e inferiores da população 1 nos anos de 1993/94, 1994/95 e 1995/96. 
PROD. DE GRÃOS

(g/parcela)

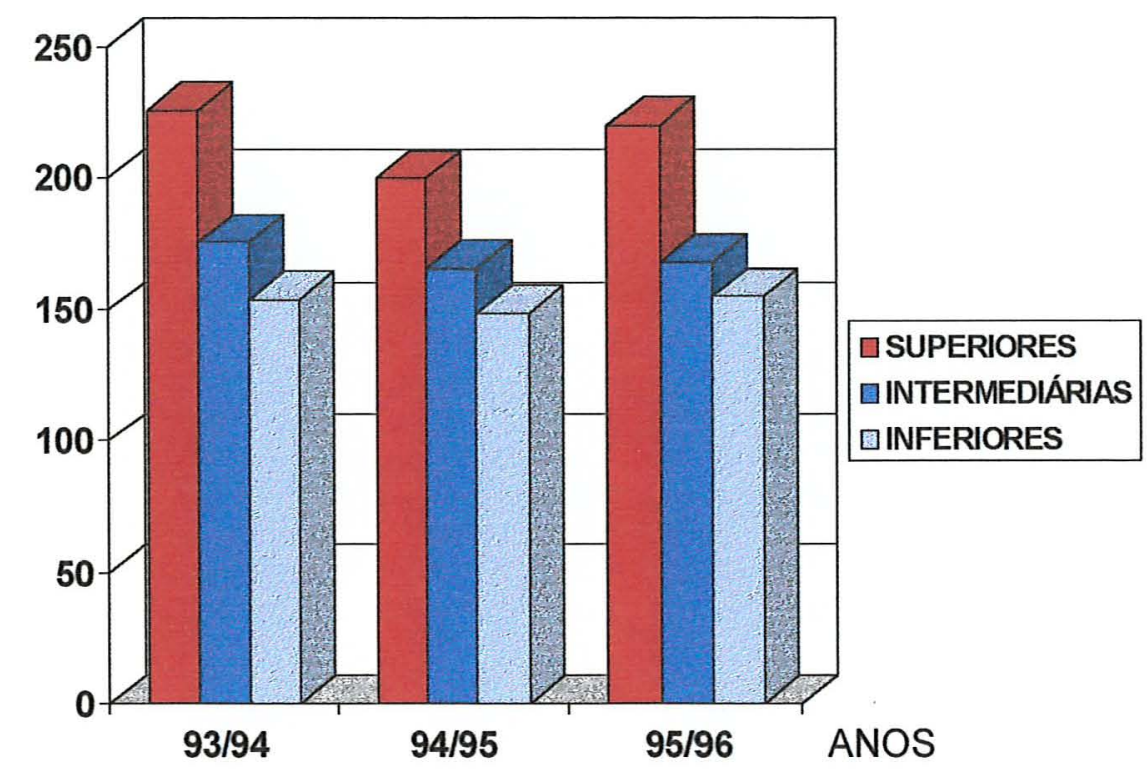

Figura 7: Médias das 20 progênies superiores, intermediárias, e inferiores da população 2 nos anos de 1993/94, 1994/95 e 1995/96. 
PROD. DE GRÃOS

(g/parcela)

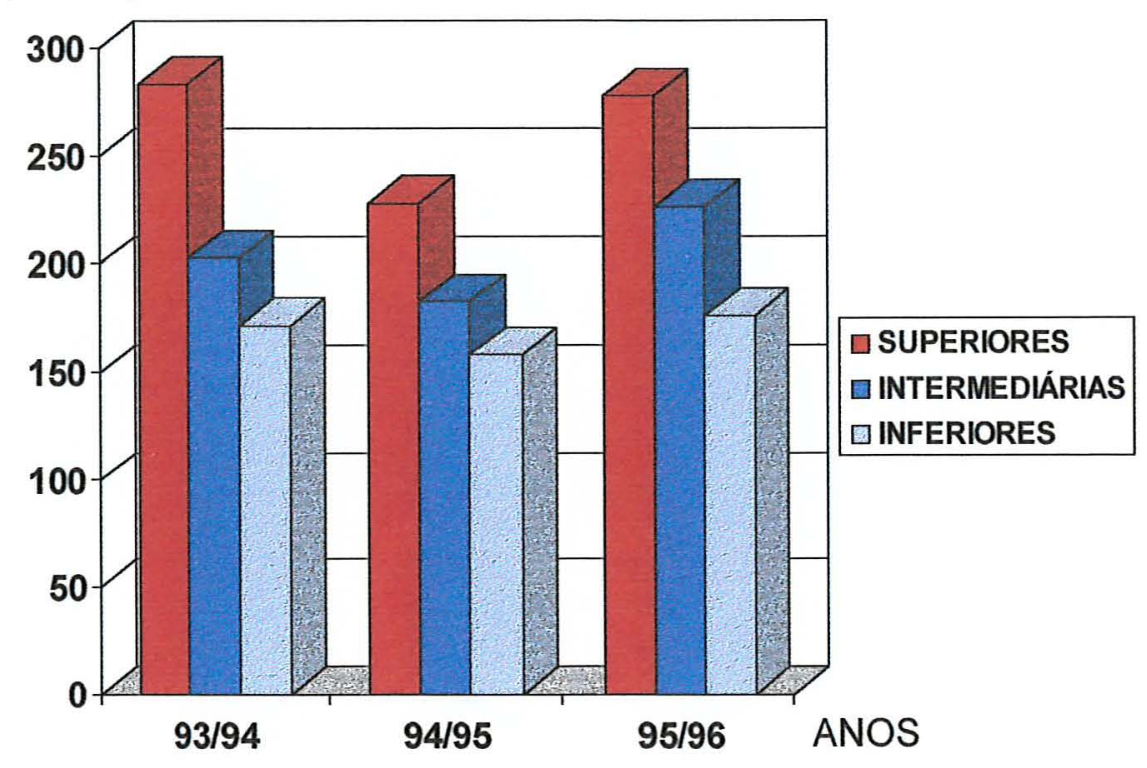

Figura 8: Médias das 20 progênies superiores, intermediárias, e inferiores da população 3 nos anos de 1993/94, 1994/95 e 1995/96. 


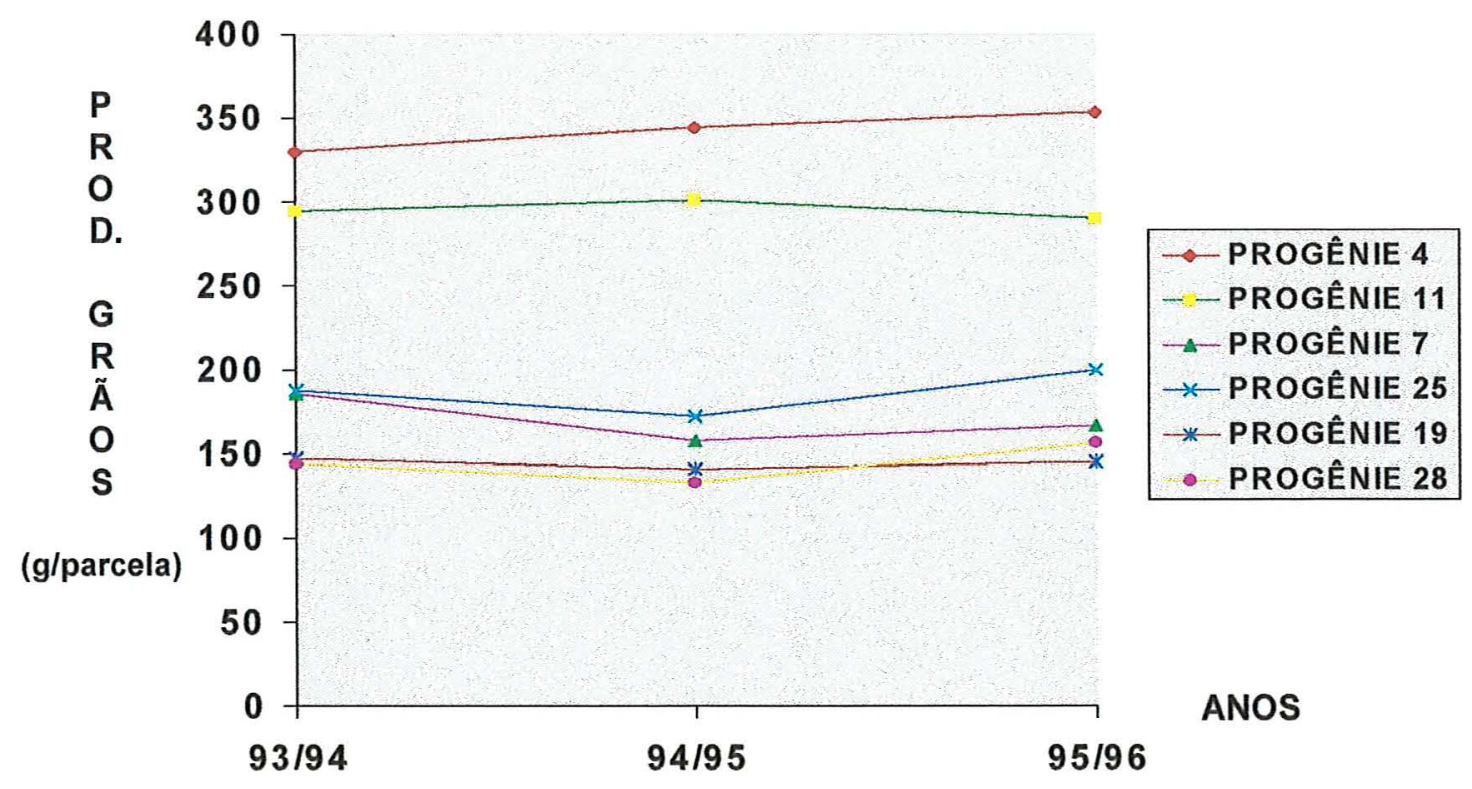

Figura 9: Médias das seis progênies mais "homeostáticas", no referente a sua performance fenotípica, correspondentes a população 1 nos anos de 1993/94, 1994/95 e 1995/96.

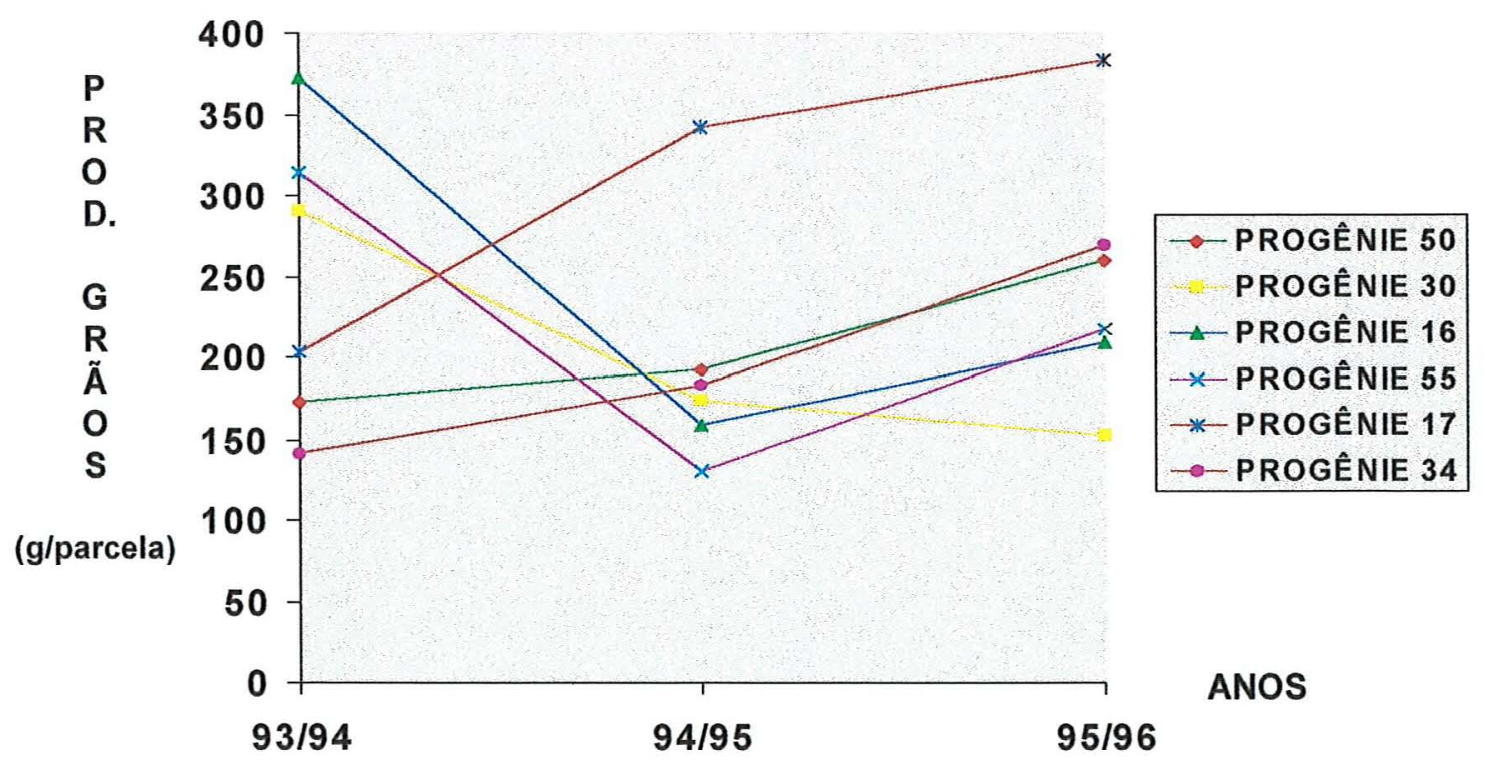

Figura 10: Médias das seis progênies menos "homeostáticas", no referente a sua performance fenotípica, correspondentes a população 1 nos anos de 1993/94, 1994/95 e 1995/96. 


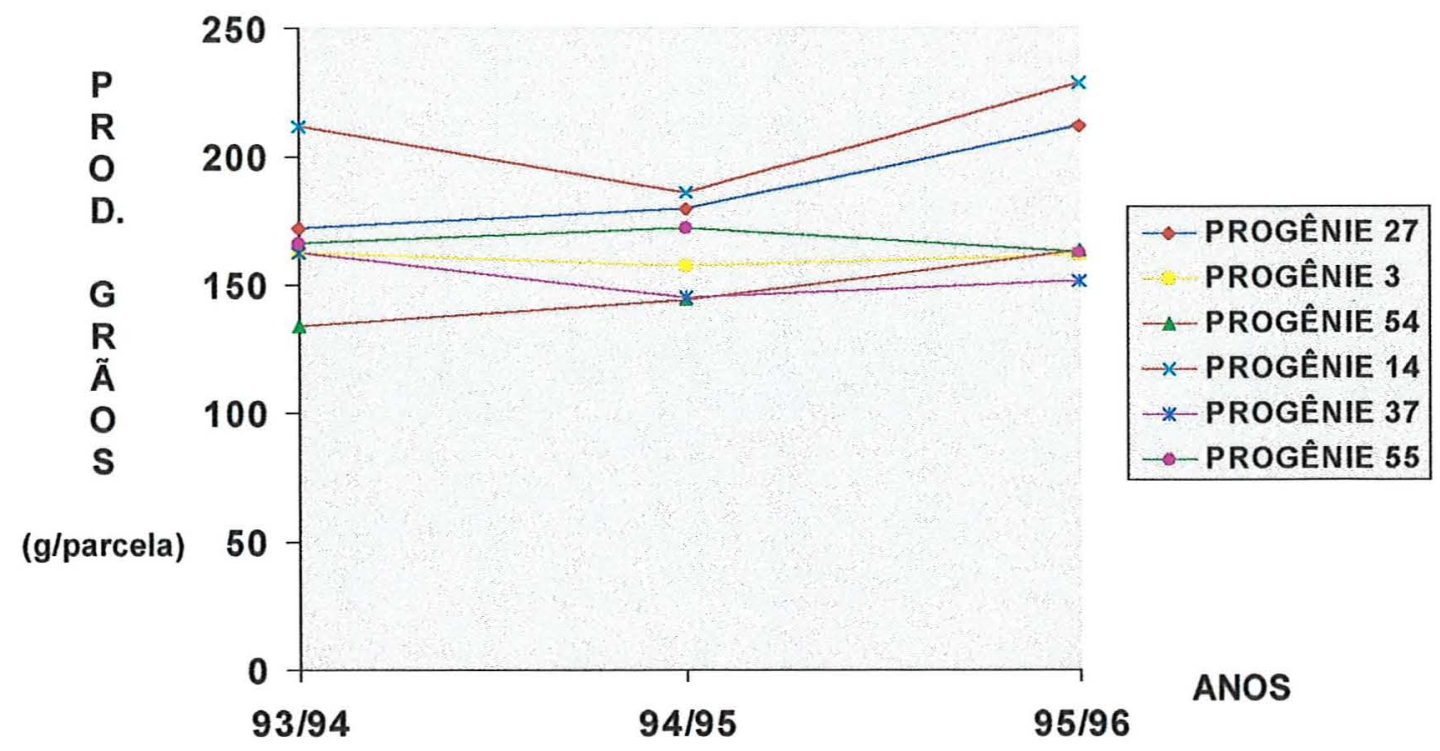

Figura 11: Médias das seis progênies mais "homeostáticas", no referente a sua performance fenotípica, correspondentes a população 2 nos anos de 1993/94, 1994/95 e 1995/96.

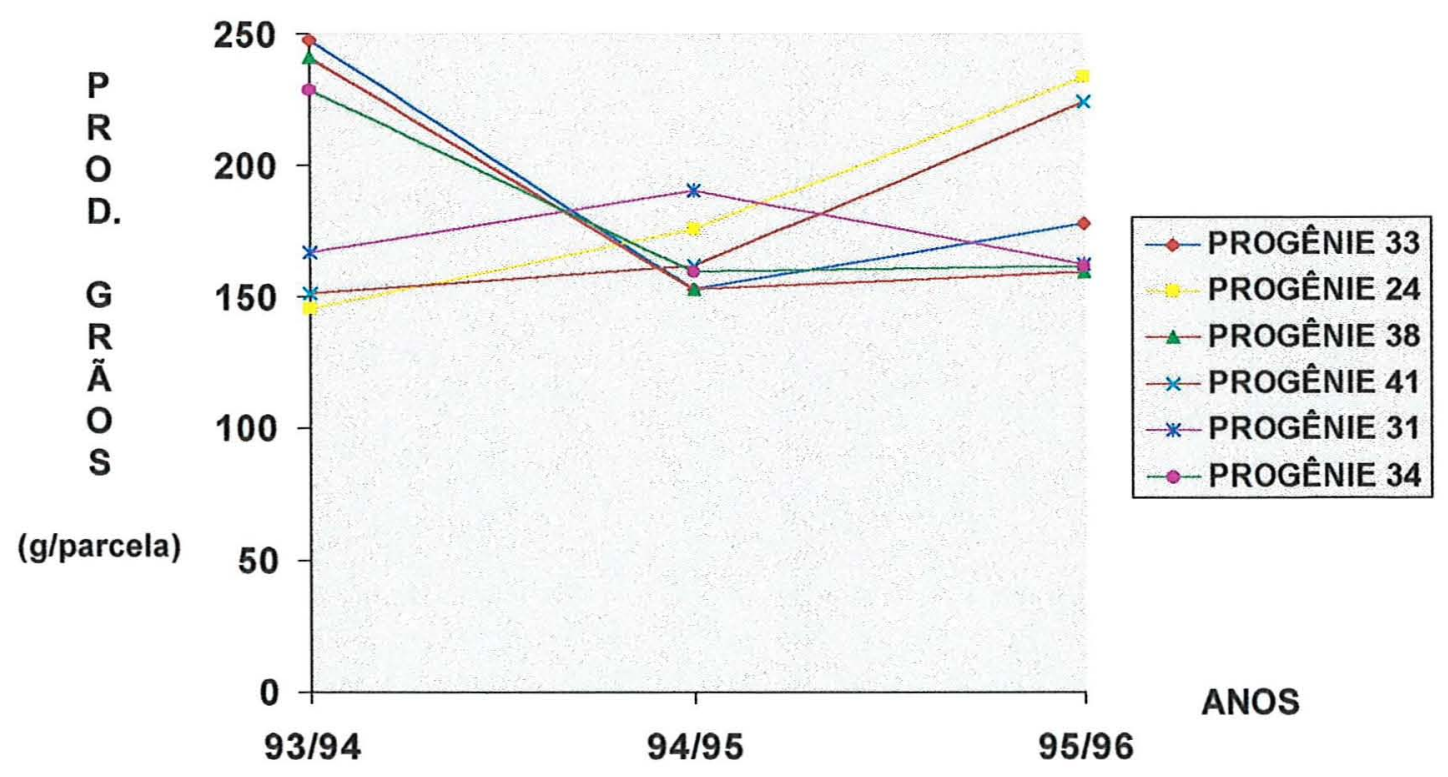

Figura 12: Médias das seis progênies menos "homeostáticas", no referente a sua performance fenotípica, correspondentes a população 2 nos anos de 1993/94, 1994/95 e 1995/96. 


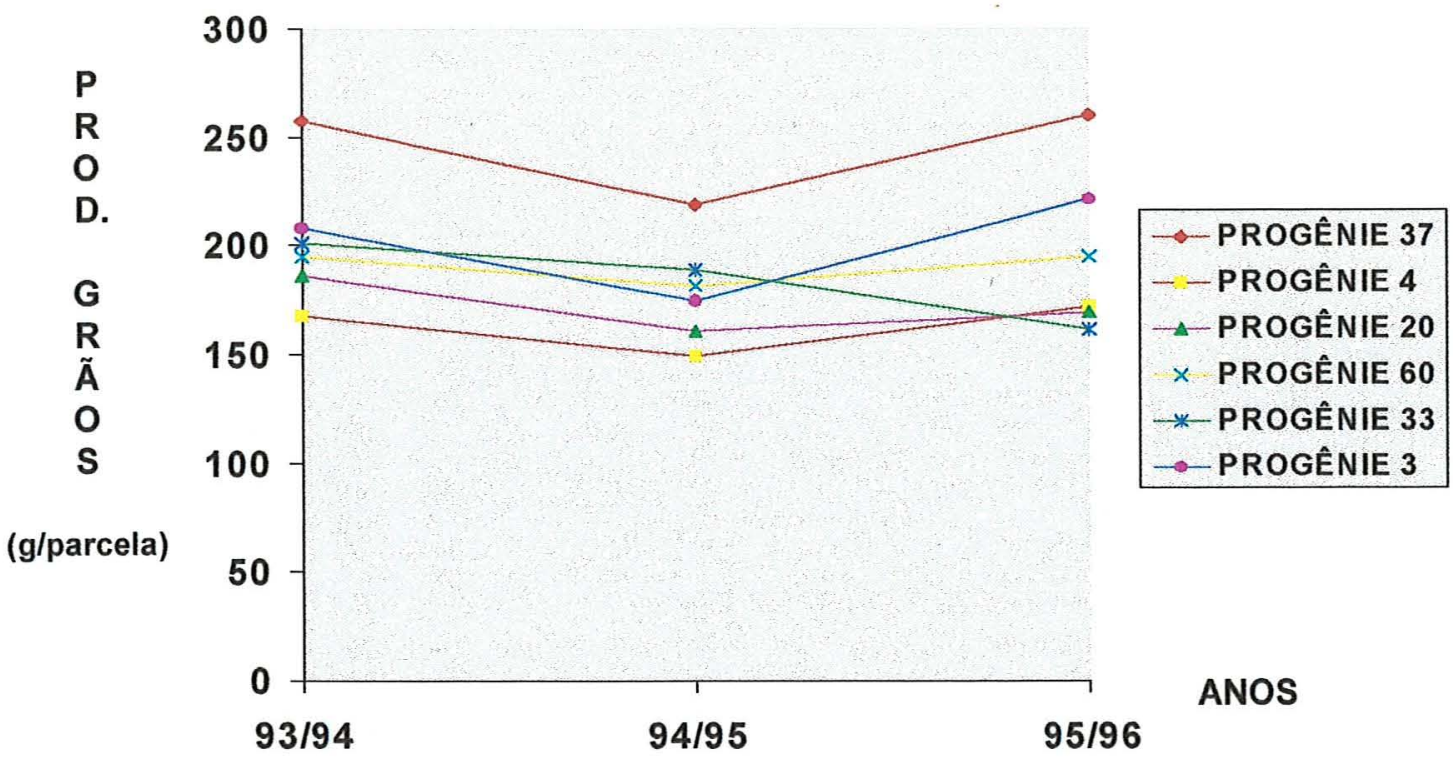

Figura 13: Médias das seis progênies mais "homeostáticas", no referente a sua performance fenotípica, correspondentes a população 3 nos anos de 1993/94, 1994/95 e 1995/96.

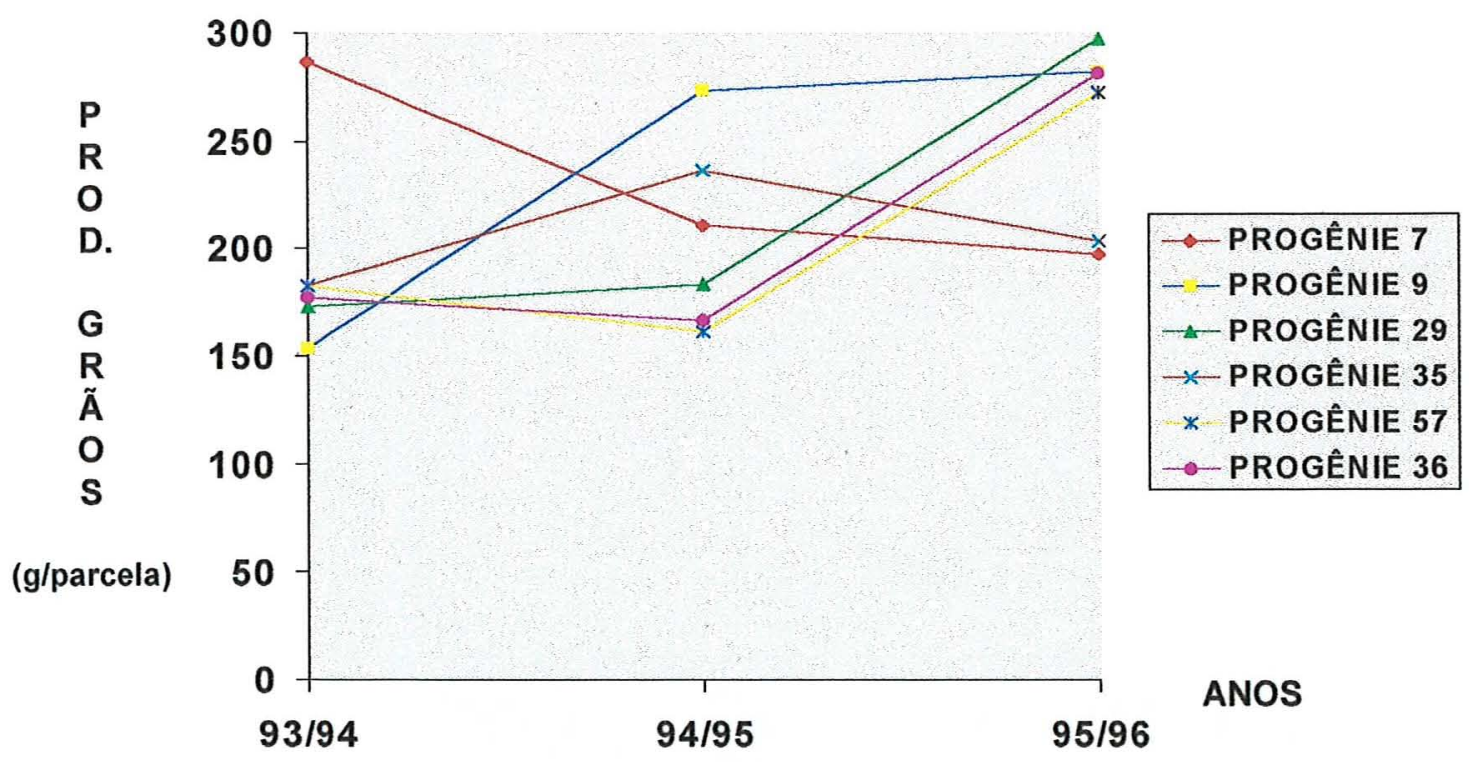

Figura 14: Médias das seis progênies menos "homeostáticas", no referente a sua performance fenotípica, correspondentes a população 3 nos anos de 1993/94, 1994/95 e 1995/96. 